UNIVERSIDADE DE SÃO PAULO

FACULDADE DE FILOSOFIA, LETRAS E CIÊNCIAS HUMANAS

ELIANE LIMONTI DA FONSECA

Os Teclados: a construção do sujeito-leitor na partitura do texto

São Paulo 2009 


\section{ELIANE LIMONTI DA FONSECA}

\section{Os Teclados: a construção do sujeito-leitor na partitura do texto}

São Paulo

2009 
ELIANE LIMONTI DA FONSECA

\section{Os Teclados: a construção do sujeito-leitor na partitura do texto}

Dissertação apresentada ao Departamento de Letras Clássicas e Vernáculas da Faculdade de Filosofia, Letras e Ciências Humanas da Universidade de São Paulo para a obtenção do título de Mestre em Literatura Portuguesa.

Área de Concentração: Literatura Portuguesa

Orientadora: $\operatorname{Prof}^{\mathrm{a}}$. Dr ${ }^{\mathrm{a}}$. Lilian Jacoto

São Paulo 
Autorizo a reprodução e a divulgação total e parcial deste trabalho, por qualquer meio convencional ou eletrônico, para fins de estudo e pesquisa, desde que citada a fonte. 
Nome: FONSECA, Eliane Limonti da

Título: Os Teclados: a construção do sujeito-leitor na partitura do texto

Dissertação apresentada ao Departamento de Letras Clássicas e Vernáculas da Faculdade de Filosofia, Letras e Ciências Humanas da Universidade de São Paulo para a obtenção do título de Mestre em Literatura Portuguesa.

Aprovado em:

Banca Examinadora:

$\operatorname{Prof}^{\mathrm{a}}$. Dr ${ }^{\mathrm{a}}$

Instituição:

Julgamento:

Assinatura:

Prof $^{\mathrm{a}} . \mathrm{Dr}^{\mathrm{a}}$. Instituição:

Julgamento:

Assinatura:

$\operatorname{Prof}^{\mathrm{a}} . \mathrm{Dr}^{\mathrm{a}}$ Instituição:

Julgamento:

Assinatura:

Prof $^{a}$. Dr ${ }^{\mathrm{a}}$. Instituição:

Julgamento:

Assinatura: 


\section{DEDICATÓRIA}

A Deus e a Nossa Senhora Aparecida, meus eternos alicerces.

Ao meu marido, companheiro, cúmplice, amigo e maior incentivador, Renato Balogh Kiss.

À Ziláh, a melhor e mais compreensiva mãe que poderia desejar.

À querida vovó, Zulmira, raio de luz que deu cor e alegria à minha vida.

Ao mеи irmão Emanuel, pelas lágrimas e sorrisos de nossa fraternidade.

Aos meus sogros, Verônica e Miguel, figuras sempre presentes, que são meus novos alicerces nesta trajetória.

Em especial, à memória de meu pai, Sebastião Santos da Fonseca, que, desde o nome, traz o mito sebástico da saudade eterna e da ausência profunda na alma. A você, pai, minha grande inspiração e força, dedico a finalização de um trabalho que você plantou: o amor pelas letras. 


\section{AGRADECIMENTOS}

À minha orientadora, Professora Doutora Lílian Jacoto, pela forma digna, responsável e competente com que dirimiu minhas dúvidas acadêmicas e compreendeu os labirintos existenciais que percorri ao longo destes anos.

À Professora Doutora Mônica Muniz de Souza Simas, pelas orientações e contribuições fundamentais concedidas durante o exame de qualificação, que me auxiliaram no desenvolvimento desta pesquisa.

À Professora Doutora Marlise Vaz Bridi, pelas contribuições acadêmicas, que muito me auxiliaram na condução desta pesquisa, e pela apresentação que me fez de Teolinda Gersão durante as disciplinas da graduação.

À Professora Doutora Maria Helena Peixoto, meu agradecimento especial pela amizade, pela atenção às minhas dúvidas acadêmicas, pelas indicações bibliográficas e pela contribuição ao progresso qualitativo desta pesquisa.

Ao meu amigo Dario Ferreira Neto, mestre por esta mesma universidade, pela atenção dedicada à leitura desta dissertação.

Aos professores Osvaldo Humberto Leonardo Ceschin, João Adolfo Hansen, Iris Gardino, Maria dos Prazeres Santos Mendes, Paola Giustina Baccin, Giliola Maggio de Castro e Pedro Garcez Ghirardi, pela contribuição que deram à minha formação acadêmica.

Ao meu amado marido, Renato Balogh Kiss, por compreender, pacientemente, os mergulhos que minh'alma fez ao longo do mestrado. Por saber ser meu cúmplice, silencioso, nos momentos de angústia, quando precisava apenas de seu olhar para acalmar meu coração. Aos seus abraços e beijos que percorreram os meus pensamentos na realização desta pesquisa. Te amo! 
À minha mãe, artista fenomenal e intuitiva, Ziláh Limonti da Fonseca, a quem jamais saberei agradecer a luta pela minha vida, as horas em claro, as ausências, as saudades e as muitas lágrimas que de seus belos olhos azuis escorreram. Mãe, obrigado por estar sempre ao meu lado, mesmo que em pensamento, por me socorrer quando precisava de um livro, ou por possibilitar que aflorassem ideias artísticas, sendo oásis quando meu horizonte parecia desértico. E obrigada por me ensinar a amar e a compreender a arte.

Ao meu irmão, Emanuel Perpétuo Limonti da Fonseca, que tanto e com tanta paciência me auxiliou nas crises com o computador, nas produções eletrônicas da dissertação e nas minhas dúvidas mais usuais. À Lucimara e ao Artur, por compreenderem quando deles roubei as horas tão preciosas de meu irmão. Manu, a você, agradeço a oportunidade de vivenciar o amor de um grande irmão.

Aos meus sogros, Verônica e Miguel, por compreenderem minhas ausências nas festas familiares, por cuidarem de minha casa e de meus belos cachorros, por me auxiliarem nessa minha trajetória de vida conjugal, profissional e estudantil, amenizando meu caminho, retirando grandes pedras e sendo o ombro amigo nos momentos de dificuldades. Obrigada pelo sorriso sempre sincero de vocês. Saibam que moram no meu coração.

Ao meu pai, que, mesmo no assento etéreo, me auxiliou academicamente, com seus livros, seus ensinamentos e, principalmente, com o amor incondicional pelas letras, que, desde que eu era criança, plantou em meu coração, e por ser a luz que guia minha caminhada.

Aos meus irmãos Ronaldo e Elisabeth, por acreditarem nesta irmã que sempre lutou por alcançar o título de mestre junto a esta universidade. E ao meu irmão William, que, mesmo distante geograficamente, tem lugar fixo em meu coração.

Ao sorriso eterno e à alegria de viver da bela Tia Rá, que me ensinou a nunca desistir diante de uma montanha, pois, no outro dia, ela pareceria apenas uma pequena colina. Àquela que conheceu as letras sozinha e as amou eternamente, o meu profundo carinho. 
À Amanda, Júlia, Belinha e Artur, crianças que iluminaram minha vida com o sorriso encantador de esperança. A vocês, o meu carinho.

À minha aluna Mariza, sua mãe Teresinha e seu amoroso pai, José, pelo apoio incansável durante a finalização do meu trabalho acadêmico. Aos cafés semanais que foram a bebida mágica das discussões acadêmicas e da amizade construída pelos laços do coração.

À minha Tia Silvia e seu esposo Sérgio Macedo, pelo acolhimento em sua casa quando do meu ingresso nesta universidade e pela confiança depositada no meu potencial acadêmico.

À Dani, à Gizele, ao Alexandre e ao Valmir, amigos especiais, que, mesmo de forma distante, permaneceram em minha mente, dando-me forças para continuar esta pesquisa.

Em Especial, à minha grande amiga Fabiana Romain, por estar sempre ao meu lado nos momentos mais difíceis, por me auxiliar nas reflexões sobre a dissertação, na produção da mesma e no apoio sempre incondicional de amiga. A você, Fabi, o meu muito obrigado e meu eterno carinho.

Aos meus alunos, que compreenderam meus mergulhos nos estudos acadêmicos e sempre me motivaram a continuar a caminhada rumo ao mestrado.

À Faculdade de Filosofia, Letras e Ciências Humanas, pela permissão à realização desta pesquisa.

À Universidade de São Paulo, pelo acolhimento que me foi dado, como aluna, moradora e pesquisadora, durante todos estes anos de pesquisa. 
Prever o leitor-modelo não significa apenas esperar que ele exista, mas também mover o texto de modo a construí-lo.

Umberto Eco 


\section{RESUMO}

FONSECA, Eliane Limonti. Os Teclados: a construção do sujeito-leitor na partitura do texto. 2009. 173 f. Dissertação (Mestrado) - Faculdade de Filosofia, Letras e Ciências Humanas, Universidade de São Paulo, São Paulo, 2009.

Esta pesquisa versa sobre a construção ética dos sujeitos na obra Os Teclados, especificamente o "eu" de Júlia, a protagonista, e do leitor. Utilizou-se como instrumento de pesquisa a análise dos elementos musicais constituintes do enredo, como melodia, harmonia, técnicas de retardamento e acordes. O estudo buscou compreender, a partir do diálogo entre Literatura e Música, os efeitos estéticos causados no leitor durante o ato da leitura da obra em questão, tendo como base a pressuposição de que a autora estabelece, previamente à escritura da obra, uma expectativa de "leitor ideal" e, a partir disso, cria, por meio dos elementos musicais, algumas estratégias de leitura que seduzirão o "leitor normal" e o manterão atento à narrativa e às reflexões que a obra veicula. Nesse mesmo sentido, a questão da indústria cultural, problematizada no enredo através da personagem Helena Estevão, também foi um tema pesquisado, com o apoio das teorias de Adorno e Benjamin. Esta pesquisa também analisa as metáforas presentes no enredo, bem como os mitos citados ao longo da narrativa e os elementos musicais, visando entender como a protagonista, por meio do contato com esses elementos, se constrói como sujeito ético, funcionando como espelho em que se projeta o leitor em seu processo de construção durante o ato de leitura.

Palavras-chave: Literatura - Música - Sujeito - Leitor. 


\begin{abstract}
This research is about the subjects' ethical construction in Teolinda Gersão's $O s$ Teclados. The subjects referred to in this study are Julia, the main character, and the reader. The operational tool used in this work was the analysis of the musical elements which have become part of the literary tissue of the narrative, like melody and harmony, delaying techniques and musical chords. So, the basis was the dialogue between Literature and Music and such dialogue was the means for the esthetical effects caused on the reader while reading Os Teclados to become clear to this researcher. But another presupposition has been laid at the beginning of this study, which is that there is a kind of "ideal reader" created in the author's mind and that such "ideal reader" operates as a kind of pattern, which leads her to create some special reading strategies to "seduce" the "normal reader", that is, to grasp and keep his attention during the act of reading. To develop this issue, the theme of the industrial culture has been treated. The starting point for the development of theme in Teolinda's novel was Julia's confrontation with Helena Estevão's ideas. This research also analyses some metaphors of the text, the myths quoted along the narrative and also the already mentioned musical elements. The aim is to understand the way the character, in contact with such elements, builds herself up as an ethical subject and operates as a kind of mirror in which the reader can project himself, building himself up by following Julia's pattern.
\end{abstract}


SUMÁRIO

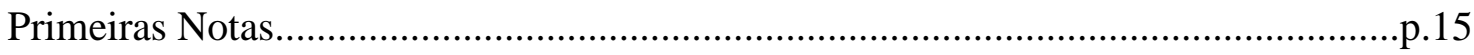

Capítulo I - Claves da Narrativa.....................................................................p. 27

1.0 Os compositores musicais: Mozart, Beethoven e Bach ............................p.27

$1.1 \mathrm{O}$ compositor Mozart …...........................................................p.32

1.2 Beethoven - "O poeta dos sons"..................................................p.38

1.3 "As muitas vozes" de Johann Sebastian Bach - "o músico

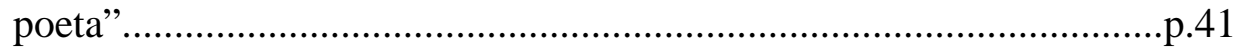

2.0 As outras relações músico-sociais ........................................................p.44

3.0 A multiplicidade de teclados ..............................................................p.46

4.0 A trapezista - senhorita Maciel............................................................ p.49

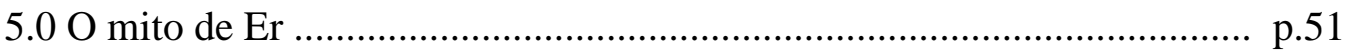

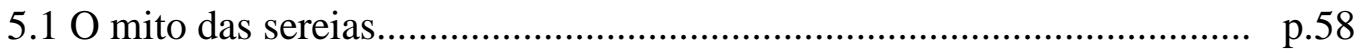

Capítulo II - Júlia e seus primeiros insights sobre a relação Arte-Público................ p.64

Capítulo III - O caminho das notas musicais: $1^{\mathrm{a}}$. Parte: Melodia............................. p. 81

6.0 O diálogo entre as artes: Literatura e Música....................................... p.81

$6.1 \mathrm{O}$ elemento musical na obra $O s$ Teclados ................................ p.83

6.1.1 A Tonalidade...................................................... p. 85

6.1.2 As claves em Os Teclados ..................................... p.86

6.1.3 A tonalidade e a clave............................................ p.87

6.1.4 A tonalidade musical e a literária.............................. p.88

6.1.5 A melodia........................................................... p.89

Capítulo IV - O caminho dos arpejos músico-textuais d'Os Teclados - 2ª Parte:

Harmonia............................................................................................. p. 97

$7.0 \mathrm{O}$ refrão, ritornelo ou estribilho..........................................................p. 110 
8.0 A técnica de retardamento.................................................................p. 112

Capítulo V - A escuta da partitura literária...............................................................p.115

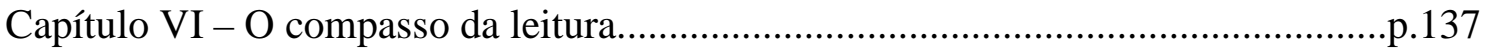

Últimos Acordes ..........................................................................................p. 162

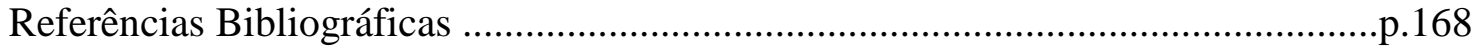




\title{
Primeiras notas...
}

\author{
O homem que não tem música em si mesmo, \\ e que não se comove com a doçura e a harmonia dos sons, \\ é capaz de traições, conspirações e de pilhagens. \\ William Shakespeare, \\ O mercador de Veneza, Ato V, Cena -1: Lourenço.
}

\section{OS UNIVERSOS FICCIONAIS DE TEOLINDA GERSÃO}

Teolinda Gersão e seus universos ficcionais começam a emergir na literatura portuguesa no ano de 1981, com a publicação de seu primeiro romance O Silêncio. Unindo-se aos escritores do período posterior à Revolução dos Cravos, busca dar vazão à consciência de seu compromisso, enquanto escritora, com a realidade políticohistórica da época.

Assim como muitos autores seus contemporâneos, Gersão, impulsionada pela criação literária, introduz em suas primeiras obras o intimismo e o questionamento interno das personagens femininas e a exposição de suas relações com o meio opressor da realidade portuguesa da época. Exemplos desse impulso literário são suas primeiras obras: O Silêncio (1981) e Paisagem com Mulher e Mar ao Fundo (1982).

Já nesses primeiros romances podem ser constatadas as duas tendências contemporâneas do romance português, as quais Isabel Pires de Lima, em Ainda há contos de fadas?:O caso de Os anjos de Teolinda Gersão. (p. 01) caracteriza da seguinte forma:

1. uma forte tendência para a criação de universos auto-referenciais ou narcísicos, remissivos de modo especular para ambientes sociais e urbanos contemporâneos e familiares da autora: artistas, professores, médicos, personagens femininas inquietas que se autoquestionam e questionam o processo da criação estética; 
2. uma clara propensão experimentalista, que subordina a linearidade narrativa a diversos processos de decomposição, a movimentos de descontinuidade, a rupturas súbitas e a um procedimento simultâneo de autodescrição reflexiva.

Nos romances de Teolinda Gersão, as protagonistas são personagens femininas, enfocadas em momentos de reflexão sobre a sua condição de existência diante do outro ou diante de situações sociais já cristalizadas pelos hábitos cotidianos. Em O Silêncio, a personagem Lídia protagoniza uma relação de incomunicabilidade (tema recorrente no conjunto da obra da autora) em relação ao marido e ao papel social que lhe é atribuído enquanto esposa e dona de casa.

Durante a narrativa, qualquer tentativa de diálogo entre ambos resulta infrutífera. Eles se mantêm lado a lado, porém sem estabelecerem nenhuma comunicação autêntica. A narrativa acaba mimetizando essa incomunicabilidade por meio de uma ruptura em sua linearidade. O leitor é lançado aos pensamentos de Lídia e, posteriormente, inserido novamente em cenas em que o casal se encontra em silêncio:

Lídia imaginou um corpo deitado numa praia, ao lado de outro corpo. Eram um homem e uma mulher e falavam. E o que diziam, ou o que a mulher dizia, era a tentativa de um diálogo fundo, mais fundo do que o diálogo de amor que se trava, ao nível do corpo, entre uma mulher e um homem. Ela procurava uma forma de encontro, através das palavras, um encontro que era, antes de mais, consigo própria, e só depois com o homem que escutava. [...] Agora a imagem estava partida, pensou fazendo a areia correr por entre os dedos, e não havia outra coisa a fazer com ela senão deixá-la resvalar para o nada. (GERSÃO, 1981, p.11-20).

A repetição do verbo "falar" e de suas variantes (“diziam”, "dizia", "tentativa de diálogo", "diálogo") enfatiza a tentativa de comunicação e a ineficácia desse ato da protagonista, que, de maneira frustrada, acaba por confrontar-se com o vazio do existir, sugerido pela areia que se esvai por entre os seus dedos. A propósito, é importante chamar a atenção para o papel da voz narrativa, que conduz o leitor primeiro para a tentativa da protagonista de estabelecer um diálogo com o marido, depois para o 
insucesso de sua atitude, quando o leitor é levado a voltar o seu olhar para a solidão de Lídia, no final do fragmento.

Trata-se do início da obra. Nele o narrador remete o leitor a uma cena na praia, em que há um diálogo entre um homem e uma mulher. Após acompanhar esse início da história, o leitor é surpreendido em sua leitura por uma espécie de "digressão psicológica".

Já Os Guarda-chuvas Cintilantes, de 1984, aproxima-se da segunda vertente mencionada por Isabel Pires de Lima. A obra é percorrida pela busca de liberdade na narrativa, pela tentativa da criação de uma nova estética e pela discussão desses elementos na microestrutura, tal como se observa no excerto abaixo:

Vou continuar a escrever o livro, pensou alegremente voltando para casa.

Mas quando chegou a casa o livro transformou-se em pássaro e voou. (GERSÃO, 1984, p. 130).

A metáfora do pássaro é, por natureza, emblema de liberdade. O livro se transformou em um pássaro que sai voando. Voando o livro, livre o pássaro, pode-se, então, ler tal imagem como a autonomia da obra literária, antes escravizada aos limites da moldura do gênero e da autoridade do autor. Observa-se ainda a transmutação da imagem do livro em pássaro, bem como a sua humanização, saída que só é possível porque o diário se faz palavra escrita e, portanto, ficção.

A partir do fim da década de 80 e durante a década de 90, nota-se, na produção literária de Teolinda Gersão, um retorno ao romance linear, com uma trama coesa, envolvendo, geralmente, uma protagonista que vive um intenso monólogo interior acerca de sua família e suas relações sociais.

Com O Cavalo de Sol (1989), A Casa da Cabeça de Cavalo (1995) e ainda A Árvore das Palavras (1997), tem-se o retorno a esse romance mais linear e repleto de plasticidade e simbologia. Segue abaixo um trecho da obra A Casa da Cabeça de Cavalo:

A Casa tinha cabeça de cavalo. Ou se quisermos, mais prosaicamente: tinha uma cabeça de cavalo na parede. [...] 
É talvez inútil dizer, porque esse facto logo se tornará por demais notório, que o cavalo entrava e saía livremente da Casa [...] (GERSÃO, 1995, p. 13).

Neste trecho, as imagens da Casa e do Cavalo fundem-se numa terceira imagem, uma Casa-Cavalo, para, em seguida, serem desagregadas em partes que, ao longo do romance, articulam-se nesse "vai-e-vem" de imagens que, ora fundem-se, como CasaCavalo, ora se fragmentam como Casa e Cavalo.

A narrativa de A Casa da Cabeça de Cavalo, que seguia a trilha do romance progressivo, é entrecortada por trechos que lembram a estética surrealista, como se dá em Os Guarda-chuvas Cintilantes. O universo ficcional de Teolinda, nesse período, mantém uma narrativa só aparentemente linear - no fundo, rompe com a tradição romanesca por meio da inserção de trechos que realizam uma espécie de digressão ou de imagens que obedecem à lógica de outras estéticas, como a surrealista, por exemplo. Nesse sentido, o cuidado com a imagem e a construção da linearidade do romance fazem a história de uma nova escrita na contemporaneidade portuguesa e inauguram um novo tempo no conjunto ficcional de Gersão.

Esse mesmo trabalho cuidadoso com as imagens aparece na obra A Árvore das Palavras. No trecho a seguir, por exemplo, não só a imagem é trabalhada esteticamente, mas o místico e a magia também invadem a narrativa:

[...] e houve um dia em que ela [Loia] ressuscitou um cocoricó, depois de primeiro o ter matado na mesa de pedra da cozinha, mergulhado em água a ferver depenado, sentada num banco, à entrada do quintal. [...] Loia abre-lhe os olhos levantando as pálpebras caídas, alisa-lhe as penas, sopra-lhe para dentro do bico. O galo levanta o pescoço, sacode as asas, abre finalmente os olhos. Agora está de pé, em cima da mesa, e começa a cantar. (GERSÃO, 1997, p.11-12).

No trecho acima, Loia, empregada da casa, mata um galo e, após executá-lo, ressuscita-o como em um passe de mágica. Ela reúne os restos do animal, abre-lhe as pálpebras já caídas e assopra seu bico ("Loia abre-lhe os olhos levantando as pálpebras caídas, alisa-lhe as penas, sopra-lhe para dentro do bico”). O sopro de Loia devolve a 
vida ao animal. A narrativa segue a lógica linear, mas as descrições ao longo dela são elaboradas por meio de uma outra lógica, seguindo a montagem e desmontagem de imagens que geram reflexões. É a lógica do "olhar". O leitor precisa olhar o texto, elaborar a imagem e, pelo ato da reflexão dessa imagem projetada em sua mente, refletir sobre os temas expostos.

$\mathrm{Na}$ prosa de Teolinda, as personagens vivem um difícil exercício de sobrevivência frente à alternância de perdas e ganhos no mundo em que estão inseridas. Cada uma dessas personagens aproxima-se da realidade para combater seus sistemas de dominação e vivencia o conflito de mergulhar em sua interioridade para iluminar tal combate.

Em síntese, a ficção de Teolinda move-se entre a prosa poética e metafísica e a prosa ideológica. Há uma oscilação entre a entrega fascinada à construção de uma nova linguagem e os estados da subjetividade humana.

No caso de Os Teclados (1999), a aparente centralização no enredo não consegue encobrir a ruptura com a tendência reconhecida na primeira fase do universo ficcional de Gersão. A narrativa, a princípio, parece iludir seu leitor no sentido de imergi-lo na tradição do romance linear do século XIX. Todavia, já no início, percebese que o fluxo de troca entre a tradição do romance linear e a inovação do contemporâneo perpassa o discurso narrativo a todo momento.

"Em criança ela rezava por Mozart” (GERSÃO, 1999, p. 07). Essa primeira frase do romance parece anunciar que a obra dialoga com uma arte específica, a Música. Como a própria narradora diz, "Havia como na música uma liberdade e um determinismo - a última frase de um romance, por exemplo, estava já contida na primeira. Era sempre o tom que decidia tudo. Uma vez encontrado era como uma chave. Uma clave.“ (GERSÃO, 1999, p. 52). Portanto, a primeira frase de um romance já anuncia qual trajetória se deve seguir para interpretá-lo.

Assim sendo, compreender o diálogo entre as artes, Literatura e Música, neste romance, é imprescindível para estabelecer esta nova linha na obra ficcional de Teolinda. De fato, a narrativa mantém parte da linearidade; entretanto revela a fragmentação do "eu" da protagonista Júlia, que, à medida que a trama evolui, constróise como sujeito.

Júlia é uma heroína em processo de aprendizagem e de formação ética, e isso ocorre por meio da construção de sua autoconsciência, num processo que se expõe diretamente ao leitor. Para conduzir-se nesse processo de construção de si, a autora lhe 
oferece unicamente o teclado e o mundo que a cerca. $\mathrm{O}$ teclado, como ela mesma define, é, em si mesmo, um paradoxo, pois é infinito e limitado: "Não lhe disse que tinha medo de se afogar no teclado. De desaparecer dentro dele. Não lhe falou do seu medo de improvisar, das frases que lhe andavam na cabeça e mesmo em sonhos voltavam e não achavam solução até implodirem ou explodirem [...]" (GERSÃO, 1999, p.49).

Júlia tem medo dessa infinitude do teclado, pois é por meio dele que ela se constitui como sujeito, buscando uma grande "Verdade" sobre a vida. Ela tem medo de se perder nesse labirinto em que se encontra. Por outro lado, além dos medos enfrentados, ela se farta do limite social, do controle que lhe é imposto e que é mimetizado, na obra, por Tio Octávio:

Nessa época tio Octávio ouvia sinfonias e concertos sentado na poltrona ao canto da janela, arrancando pêlos da orelha e palitando os dentes. Praguejava sempre que alguém, inadvertidamente, abria a porta, batia com o punho na mesa de camilha como se tentasse afugentar, pelo barulho, o intruso que entretanto retrocedera rapidamente e desaparecera na profundidade do corredor. (GERSÃO, 1999, p.07).

O tio é a personagem que representa a opressão pelo grito, pela violência, não admitindo ser interrompido. Júlia inicia sua construção enquanto sujeito opondo-se a ele por meio de sua preferência musical. Enquanto ela reza por Mozart, o tio escuta Beethoven com concentração.

Já o medo da desordem de si, da fragmentação (típica do homem moderno) é representado pelo Tio Eurico, o louco,

A ideia de que era igual a ele, de que podia enlouquecer como ele. Também ela fugia de casa, vagueava pelas ruas, se fechava no quarto, escondia segredos. Também a ela alguma coisa a assaltava, a música era uma onda de energia desencadeada e solta, à mercê da qual ficava sem defesa. O Tio Eu. (GERSÃO, 1999, p.40). 
Tio Eurico não consegue dominar o discurso verbal, ou seja, não consegue se comunicar com ninguém da casa. Tenta, por meio de uma "música primitiva" (somente os ritmos) se comunicar com Júlia. O desespero de Eurico em sua tentativa de existir no mundo e a ausência de comunicação fazem com que ele espelhe o horror de Júlia de enlouquecer também, pois ela, assim como Eurico, cada vez menos se comunica, sendo oprimida por aquela casa em silêncio constante: seus tios, seus professores, a própria música.

Júlia é uma órfã criada por tios idosos, Tia Isaura e Tio Octávio; vive em um ambiente sem aconchego nem diálogo possível (na verdade, na casa inteira não há diálogo): Isaura e Armênia (a empregada) são surdas, Tio Octávio só vê a si mesmo, Tio Eurico é louco e ela não consegue compreender as tentativas que ele faz para se comunicar. A música constitui, ao longo do romance, o eixo ao redor do qual giram todos os habitantes da casa, sem, no entanto, conseguirem fazer dela um meio efetivo e eficiente de comunicação entre eles. Sim, pois a linguagem musical é usada por cada um de forma diversificada: Eurico mal consegue acompanhar a melodia tocada por Júlia ao piano; Octávio tem uma leitura sua sobre Beethoven, que se contrapõe à leitura musical de Júlia que, por sua vez, elege Mozart como seu protegido. Tia Isaura via na música uma linguagem social, útil para obter "bons casamentos" e depois um fardo a ser carregado. Assim, percebe-se que "ora as partituras falam e conduzem um raciocínio ou uma inspiração que despertam a consciência para a realidade circundante; ora oprimem e alienam o sujeito num mundo de surdez." (JACOTO, 2003).

Nesse universo da linguagem musical, sem comunicação legítima, Júlia está fadada a tocar no silêncio, pois não quer se submeter às exigências dominantes de Tio Octávio nem às exigências sociais de Tia Isaura. Assim, cria um teclado de papel, "uma metáfora da metáfora dos teclados que escrevem sua existência para tocar inaudivelmente." (Idem). Para ela, ouvir era uma filosofia, ainda misteriosa, não compreendida, ou, na sua definição,

Ouvir era deixar o mundo entrar em si. Ficava sem defesa, escutando. O som seguia o seu curso e ela deixava de existir separadamente, tornava-se parte do que acontecia. O que era também um risco. Quase de morte, pensava às vezes. Porque a música, de algum modo, estilhaçava-a, fazia-a sair de si mesma e arrastava-a para um estágio indiferenciado, não humano, contra o qual a música finalmente triunfava. (GERSÃO, 1999, p.16). 
Além do grande diálogo entre Literatura e Música e a partir dele ocorre, também, um outro diálogo silencioso entre Júlia e a própria escritora que lhe dá vida, representada pela personagem Helena Estevão, célebre escritora com cuja entrevista, publicada num jornal, Júlia se depara numa tarde em que vai ao dentista. Essa escritora, que dedilhava um outro teclado, o do computador, falava de sua vida num mundo que reduzia tudo aos valores de troca e do papel da arte naquele mundo vazio - qual seria o sentido da arte na contemporaneidade de Júlia?

A protagonista (que, na verdade, pode ser vista como criação daquela que manipula o outro teclado, a outra linguagem) tem dificuldade em compreender as reflexões de Helena Estevão; para ela, é muito mais simples a linguagem das partituras. A partir desse momento, na narrativa, Júlia sofre com a ambiguidade da escritora e a incerteza em relação à transcendência que o teclado lhe daria. Enquanto Júlia busca construir-se na harmonia musical do texto, a escritora estabelece a conexão da protagonista com um mundo prosaico e materialista, onde a música não é a grande verdade procurada, mas apenas algo que lhe oferece alguns instantes de escape e comoção.

Nesse jogo de divergências e convergências, verifica-se o surgimento de um terceiro elemento musical, nem Mozart nem Beethoven, mas sim Bach e suas vozes, “As muitas vozes das coisas. Vozes de Bach, jogando umas com as outras, cruzando-se, convergindo, divergindo. Puro jogo, como o do mar e das ondas. Assim o mundo era feito.” (GERSÃO, 1999, p.15).

Com a entrada de Bach em cena, novamente o leitor mergulha no diálogo entre as artes que perpassa a narrativa, buscando compreender os jogos expostos nela: cada personagem parece ser uma peça de um jogo de combinações, revelando-se em alegorias desse mundo caótico, fragmentado, da contemporaneidade. Tio Octávio é a alteridade, o outro com que Júlia se confronta, talvez a construção do seu ego, assim como Tio Eurico que pode representar o não normatizado, o louco, o incompreendido, o silêncio em mimese, é a representação do "eu" da protagonista, que também pouco fala ao longo da obra, mantendo-se fechada em seu mundo interior - por isso ela tem tanto medo de enlouquecer como Eurico, o "Tio Eu".

Os professores têm papel fundamental na formação de Júlia. Palrinha se contrapõe ao professor Severiano Mendonça, o primeiro vivendo no anonimato, o 
segundo buscando a fama. Ainda há o professor de Matemática, Rogério Souto, que apresentará a Júlia uma nova possibilidade, a de outras "verdades", e, então, ela descobrirá que não há a grande "Verdade", mas a mutação de verdades durante o percurso de sua vida. Na última cena, quando Júlia se senta ao piano para tocar para uma plateia vazia, a arte é reforçada como, talvez, o único caminho possível para se buscar uma constituição ou compreensão do ser nesse mundo fragmentado, mercadológico, vazio e silenciado.

Em síntese, Teolinda realiza, ao longo da narrativa d'Os Teclados, uma reflexão sobre o papel da arte na contemporaneidade. Para isto, ela propõe um diálogo estético entre Literatura e Música, por meio de elementos comuns a ambas as artes, de modo que o leitor pense sobre o papel do artista, sobre a arte voltada para o mercado e sobre o papel do espectador, ouvinte e leitor destas artes diversas que compõem o mundo contemporâneo.

Nesse sentido, o objetivo central deste trabalho volta-se para o estudo de $O s$ Teclados. Na verdade, é privilegiada a relação entre Literatura e Música, com delimitação voltada para a verificação da presença dos elementos musicais na narrativa, do exame do papel que desempenham enquanto integrantes da estrutura e do efeito de sentido que produzem no contexto geral do romance. $\mathrm{O}$ estudo de tais elementos estruturais destina-se a investigar como Júlia se constitui como sujeito ético, assim como o sujeito-leitor da obra, ao sofrer os efeitos estéticos nela construídos.

Para tanto, esta pesquisa compreende que a constituição do sujeito dentro de uma sociedade moral (regras sociais) acontece a partir da observação e reflexão dos elementos éticos estabelecidos por um grupo e da transformação desses elementos em valores pessoais, ou ainda, da negação de tais valores, constituindo-se assim o chamado sujeito-ético. Portanto, tal constituição ocorre por meio de um processo de identificação ou negação dos valores éticos presentes em um grupo ou pessoas que fazem parte de uma sociedade.

Para analisar Júlia em sua trajetória de constituição ética dividiu-se esse estudo em seis capítulos. O primeiro, intitulado Claves da Narrativa, visa compreender as metáforas fundamentais para o estudo da constituição ética da protagonista Júlia. Para se estudar os compositores musicais, os estudos de Caldeira Filho, que escreveu: $O s$ compositores musicais, e os biógrafos MASSIN \& JEAN (1997), com sua obra História Ocidental da Música, são os balizadores dessa parte da análise, que enfatiza o papel de Mozart, Beethoven e Bach em Os Teclados. Já o estudo sobre as formas silenciosas em 
Os Teclados, como as reflexões de Júlia, ou ainda o teclado de papel, tem por base teórica a obra As Formas do silêncio, de ORLANDI (2007). A análise dos mitos que são citados na narrativa, como o Mito de Er e o Mito das Sereias, está apoiada, respectivamente, n'A República, de Platão, e na Odisseia, de Homero. O estudo do Mito de Er ainda está pautado em dois artigos: o primeiro da filósofa Marilena Chauí, intitulado $O$ Mito da Caverna e o Mito da Reminiscência, e, posteriormente, o artigo: $O$ mito de Er: Sartre e o platonismo às avessas?, de Thana Mara de Souza. Ainda para analisar o Mito das Sereias, foram utilizados os estudos de Álvaro Cardoso Gomes em seu livro O poético: magia e iluminação.

No segundo capítulo, intitulado Júlia e seus primeiros insights sobre a relação Arte-Público, procura-se traçar um estudo das reflexões da personagem Helena Estevão, que despertam os pensamentos de Júlia sobre a arte e a relação do público com o artista. Este capítulo, além de complementar, de forma fundamental, os estudos sobre a constituição ética de Júlia, ainda complementa a análise da formação de outro sujeito ético na obra, isto é, o leitor, ou melhor, o ideal de leitor projetado na protagonista e abordado nesse capítulo. Como fundamentação teórica foram utilizados os estudos de Walter Benjamin sobre a obra de arte na era de sua reprodutibilidade técnica, em sua obra Magia e técnica, arte e política, (1985). Os estudos de Theodor Adorno sobre a indústria cultural e seus efeitos sobre o consumo da música na era da comunicação de massa, nos célebres ensaios: "Indústria Cultural-Iluminismo como mistificação das massas" e "Crítica cultural e sociedade"(2006), também serão basilares para a construção do capítulo. O estudo de Compagnon (2001) em sua obra $O$ demônio da teoria - literatura e senso comum balizou a discussão sobre as comunidades interpretativas, tantas vezes evocadas ao longo d'Os Teclados.

No terceiro capítulo, $O$ caminho das notas musicais $-1^{a}$. parte: melodia, iniciase o estudo sobre os elementos musicais presentes na obra. Para tal, primeiramente, buscou-se uma apresentação sobre o diálogo artístico (semiótico) entre Literatura e Música, como estudo-chave para se compreender, a posteriori, os efeitos estéticos que tais elementos causam no leitor da obra. Para isso, foram usados os estudos sobre estética, de JIMENEZ, em seu livro $O$ que é estética? (1997), bem como a obra $O$ Pacto primordial entre mulher e escrita - Teolinda Gersão e a atual prosa feminina portuguesa (2008), de Maria Heloísa Martins Dias, que também conduz parte deste estudo. 
Em um segundo momento, ainda no terceiro capítulo, são aprofundados, especificamente, os estudos sobre música, para, então, se procurar compreender como os elementos musicais agem na narrativa. Desse modo, foi fundamental, para a produção final do capítulo três, assim como do capítulo quatro, o uso do Dicionário Musical Brasileiro, de Mário de Andrade, assim como de sua obra Pauliceia Desvairada, para os estudos dos elementos melódicos e harmônicos. Assim, também se aprimoraram tais estudos com base na obra Literatura e Música (1990), de Luiz Piva, e Expressão e Comunicação na Linguagem da Música (1996), de Sérgio Magnani, além das obras já citadas de Mário de Andrade também balizaram os estudos sobre as técnicas de retardamento, refrão e polifonia poética, abordados no quarto capítulo, intitulado $O$ caminho dos arpejos músico-textuais d'Os Teclados - $2^{a}$.parte: Harmonia. Após o estudo sobre os elementos musicais, o quinto capítulo, A escuta da partitura literária d'Os Teclados, tem por objetivo estudar os efeitos estéticos que esses elementos musicais causam no leitor. Para isso, a fundamentação teórica foi buscada na linha da Estética da Recepção, de Wolfgang Iser. Desse modo, sua obra $O$ ato da leitura - Teoria do Efeito Estético (vv. 1 e 2, 1999) é basilar para essa análise. Também foram de suma importância a obra A Literatura e o Leitor - textos de Estética da Recepção (2002), de seleção, coordenação e tradução de Luiz Costa Lima, e ainda os estudos de Compagnon, na obra já citada para estudo sobre as comunidades interpretativas.

O sexto e último capítulo, O compasso da leitura, procura estudar o tempo e sua importância para a formação do "eu" de Júlia dentro da obra. Para isso, foram usados os estudos de pensadores que se debruçaram sobre essa categoria, como Santo Agostinho, em As Confissões, e Platão, em Timeu, Crítias, As Leis. Meyerhoff, em sua obra $O$ Tempo na Literatura, foi de fundamental importância para se compreender o fio condutor realizado por Teolinda ao citar os estudiosos do tempo, como Pitágoras, Platão e Kepler. A obra A dança do universo, do físico Marcelo Gleiser, ampliou as visões sobre o tempo e a sequência lógica, em Os Teclados, dos estudos teóricos sobre o tempo. Por fim, como este capítulo também envolve o tema da "Ética" para a compreensão de como se constitui o sujeito ético, o autor Pergentino S. Pivato ofereceu a fundamentação teórica sobre ética.

A seguir, serão abertos os estudos da narrativa de Os Teclados. Utilizou-se para análise a primeira edição dessa obra, da editora Dom Quixote, Lisboa, de abril de 1999. No capítulo de abertura, o exame do plano da fábula inicia o percurso para compreender a constituição ética de Júlia e do leitor enquanto sujeitos. 
CAPÍTULO I

CLAVES DA NARRATIVA 


\section{CAPÍTULO I}

\section{CLAVES DA NARRATIVA}

A protagonista Júlia, como já foi dito, constrói-se como sujeito a partir das relações sociais em que se envolve. O narrador, por meio do monólogo interior, revela os pensamentos da garota, suas relações com os parentes em sua casa, com os amigos, os professores, com as teorias que, encantada, vai, gradativamente, assimilando na interação com elas. É no contato com esse universo em mutação e desenvolvimento que o leitor poderá perceber como Júlia se constitui eticamente como sujeito ao longo da narrativa.

Tal percepção depende da compreensão de certos detalhes estruturais do romance, como a evocação de certos compositores musicais, o episódio da trapezista, a metáfora dos teclados, que constituem elementos balizadores para se compreender a formação da protagonista, e que serão analisados a seguir.

\subsection{Os compositores musicais: Mozart, Beethoven e Bach.}

Ao iniciar a obra com a frase: "Em criança ela rezava por Mozart" (GERSÃO, 1999, p.07) referindo-se ao compositor, e, posteriormente, citar Beethoven, aludindo ao modo como o tio Octávio apresentava o compositor à pequena sobrinha, "Beethoven, dizia no fim abrindo os olhos e levantando o dedo indicador, [...]” (GERSÃO, 1999, p.08), Gersão apresenta ao leitor uma das fortes referências a serem interpretadas em $O s$ Teclados: os compositores musicais.

Aparece na obra, com maior destaque, a citação de três compositores: Beethoven, Mozart e Bach. Cada qual deve ser primeiramente compreendido no âmbito da narrativa e, posteriormente, a análise traçará um percurso extratextual, indicando correlações entre suas composições artísticas e Os Teclados, bem como entre suas biografias e suas respectivas "marcas" no enredo.

O primeiro compositor a ser apresentado é Mozart, e, de modo muito peculiar, há no livro uma criança (Júlia) que reza por ele. Obviamente, o leitor poderá pressupor 
que se trata de uma pequena musicista, conhecedora, ainda que precariamente, de música clássica, vendo nesse compositor uma pessoa necessitada de preces para "salválo" das injustiças cometidas contra ele: no enredo, esse "algoz" só poderá ser, aos olhos de Júlia, o tio Octávio.

Nesse sentido, essa inferência, feita a partir da frase de abertura do romance "Em criança, ela rezava por Mozart.” (GERSÃO, 1999, p.07), pode ser confirmada depois que o leitor é apresentado a tio Octávio e suas defesas entusiasmadas do compositor Beethoven. Assim, a fé infantil, aparece, na abertura do romance, como um modo inicial que a protagonista tem de apreender, compreender e ligar-se ao mundo (e com o que ele tem para ela, de mais sagrado: a música). Trata-se de um modo de conhecimento que não passa pelo crivo da razão.

Ao longo do romance, Júlia experimentará o contato com outros modos de conhecimento. Mas o primeiro deles será essa intuição infantil, através das orações e do reconhecimento sensorial do mundo. Quando ela reza por Mozart, por exemplo, deixa entrever sua ingenuidade em acreditar que esse compositor verdadeiramente sofre com as humilhações de Tio Octávio em relação à sua música e, mais ainda, que Mozart dependeria das orações dela para ser reconhecido como grande compositor. Logo, percebe-se o primeiro modo de aprendizagem de Júlia como um processo realizado por meio da credulidade infantil. ${ }^{1}$

A aprendizagem de Júlia, no início do romance, acontece por meio de sua relação com os demais personagens e com a música. Há, entre Júlia e Tio Octávio, uma diferença de predileção. Ela gosta de Mozart, enquanto ele estabelece Beethoven como o grande mestre.

Para Júlia, “em criança”, Mozart é mais do que um compositor; é o representante de seus valores éticos/estéticos que, por sua vez, vão de encontro aos valores estabelecidos por tio Octávio (tema abordado no capítulo VI). Mozart, em Os Teclados, é apresentado como um compositor que desenvolveu uma simplicidade musical, a tal ponto que suas músicas parecem quase escalas (sequência de notas). Entretanto, ao executar Mozart, o intérprete é subitamente surpreendido por notas que rompem a "tranquilidade" da leitura de suas partituras. Nesse sentido, Mozart representa uma

\footnotetext{
${ }^{1}$ Esse modo de aprendizagem também pode ser chamado de intuição. Intuir é compreender, entender e perceber o conhecimento por meio dos sentidos. Pode-se, também, entender por intuição uma forma de conhecimento por meio de ideias adventícias. Segundo a filósofa Marilena Chaú, tais ideias são aquelas vindas de fora, isto é, aquelas que se originam de nossas sensações, percepções, lembranças; são as ideias que nos vêm por termos tido experiência sensorial ou sensível das coisas a que se referem. (Convite à filosofia, São Paulo: Ática, 1997, p. 70).
} 
composição simples, que oculta a dificuldade abruptamente revelada na execução musical. Isso aparece nas reflexões feitas por Júlia com a ajuda da voz narrativa, como se pode constatar no fragmento abaixo:

Era verdade que Mozart parecia fácil, por vezes dir-se-ia uma música de nada, quase à toa. Mas quem soubesse ouvir perceberia o que estava para lá da superfície, e esta apenas dissimulava sem realmente esconder, como um pedaço de vidro transparente. Podia ser, por exemplo, um acorde aparentemente banal, duas notas depois, a primeira muito breve, a segunda à distância de uma quarta da primeira. E depois tudo seguia com a mesma simplicidade, como se não pudesse ser de outro modo - qualquer pessoa, dir-se-ia que qualquer pessoa podia ter inventado aquela frase, até ela própria, e então a frase remetia subitamente para outro contexto: alguma coisa se anunciava naquelas pequenas notas que qualquer criança podia tocar. [...] (GERSÃO, 1999, p.12-13)

Devido a essa suposta simplicidade musical, Mozart é desprezado por tio Octávio. Todavia a figura de Mozart era conhecida por não desprezar ninguém e aprender com todas as criaturas, até mesmo os pássaros, como se nota no trecho a seguir: [...] Mas aí estava, Mozart não desprezava ninguém e aprendia até mesmo com os pássaros - era verdade, sim, Mozart aprendera muito com os pássaros, ele nunca os ouvia cantar sem pensar nisso. (GERSÃO, 1999, p.13).

Mozart também representa um estado de revelação para Júlia, uma espécie de epifania $^{2}$. Esta epifania acontece através da leitura de uma peça musical de Mozart, no momento em que a menina descobre saber ler as partituras sem precisar tocá-las. A partir dessa constatação, ela crê que ouvir era um segredo a poucos revelado, uma epifania, portanto, uma revelação, como um estado de graça, um estado de absoluta atenção às coisas. Eis a constatação que ela faz:

Ouvir era um segredo. Ela ouvia muitas coisas, algumas impossíveis. Por exemplo, bastava-lhe olhar a pauta para ouvir a música lá escrita. Acontecera-lhe a primeira vez com Mozart, mas verificara depois que

\footnotetext{
${ }^{2}$ Epifania - estado de revelação, manifestação de algo ao consciente de uma pessoa. (Dicionário Caldas Aulete $^{\text {a }}$. ed. Rio de Janeiro: Delta, S.A, 1958. p. 1798. v.2).
} 
podia ouvir qualquer música olhando apenas a partitura. Como se dentro dela alguém tocasse. (GERSÃO, 1999, p.13).

Outro elemento em comum com Mozart é o fato de apreciar sair pelas ruas ouvindo os sons do mundo, desenvolvendo a sensibilidade da audição, entregando-se aos sons mais diversos, da chuva, dos carros, do vento, do rio, da água caindo na terra, dos pássaros, enfim, os sons que não lembravam propriamente a música como construção artística, mas despertavam os sentidos dos seus ouvintes. Para Júlia, ouvir era uma entrega dos sentidos realizando-se dentro de sua mente como a regência de uma orquestra:

Às vezes ela saía, logo a seguir, caminhava na rua, tocando apenas mentalmente, para não se deixar interromper. Andava pelo meio das casas e ouvia, ouvia, e ninguém dava pontapés na porta nem gritava. As árvores balançavam os ramos e os carros passavam, as pessoas cruzavam-se com ela, mas não a interrompiam. Só quando chovia ela se abrigava debaixo de uma varanda ou no vão de uma porta, parava mentalmente de tocar e fechava o piano.

Então ouvia a chuva. Ouvir era uma absoluta atenção às coisas. Tudo ficava suspenso no vazio. E depois o som acontecia: a chuva, o vento, o mar. O vento nas folhas, no caminho de terra, nos telhados, na chuva. Agora ela ouvia a chuva, as formas fugidias da água [...] (GERSÃO, 1999, p.14).

Enquanto Júlia ouvia a música do mundo, em liberdade, caminhando pelas ruas, Tio Octávio ouvia as sinfonias de Beethoven, fechado em sua casa, desejando o silêncio para poder ouvir a música com mais atenção. Um silêncio que ele próprio rompia, com a brusquidão dos seus gestos, toda vez que esse deleite era interrompido: "Praguejava sempre que alguém, inadvertidamente, abria a porta, batia com o punho na mesa de camilha como se tentasse afugentar, pelo barulho, o intruso que, entretanto, retrocedera rapidamente e desaparecera na profundidade do corredor." (GERSÃO, 1999, p.07). Em suma, Tio Octávio exige de todos em sua casa o silêncio necessário para ele ouvir suas sinfonias prediletas. Todavia ele mesmo, aos gritos, afugenta tio Eurico, que faz barulho e atrapalha o momento de sua audição compenetrada. 
Por sua vez, Júlia, ainda criança, não tem coragem de falar aquilo que pensa para o tio. Assim, ela observa suas ações violentas, os gritos e murros na mesa, e reza em seu silêncio por Mozart.

Tio Octávio, de certo modo, enfrentava Júlia, talvez tentando educá-la ao insistir em quão maravilhosa era a música de Beethoven e quão simplista a de Mozart. No trecho a seguir, percebe-se um "tom" de vingança na descrição do olhar que Tio Octávio dirige a Júlia, como se ele tivesse ganhado uma luta, mesmo silenciosa: "Beethoven, dizia no fim abrindo os olhos e levantando o dedo indicador, quando finalmente a música parava. E olhava para ela, com um riso escarninho, satisfeito como se tivesse ganhado uma batalha." (GERSÃO, 1999, p.08). Outro trecho em que a luta silenciosa entre Tio Octávio e Júlia se dá através dos compositores pode ser percebido a seguir:

Beethoven está no alto da escada, dizia tio Octávio rindo alto e voltando a colocar o disco na estante. Mozart fica lá em baixo, tão longe que nem se vê. Nem chega ao primeiro degrau, o pobrezito, acrescentava rindo mais e brandindo no ar os punhos como se batesse em alguém. (GERSÃO, 1999, p.10).

Nesse trecho, tio Octávio, ao depreciar Mozart, parece zombar de Júlia, até porque ele sabe da sua predileção por esse compositor. O tom zombeteiro é percebido pelas risadas de tio Octávio ("rindo alto", "acrescentava rindo mais") e também pela violência traduzida pelos socos no ar, como se tivesse vencido uma batalha ("brandindo no ar os punhos como se batesse em alguém"). Ele, no papel que assume de "patriarca da casa", parece ter criado um ambiente de opressão onde impera a sua vontade sobre todas as outras. Por isso, Júlia se mantém em silêncio, rezando para que a injustiça em relação a Mozart termine. No trecho seguinte, Júlia, em silêncio, desafia tio Octávio e reza, novamente, para Mozart ser reconhecido:

Ela não respondia, engolia a resposta e a raiva. Levantava a cabeça, desafiando-o, sem dizer uma única palavra. Mas à noite rezava por 
Mozart. Para que fosse reparada essa injustiça, e o mundo reconhecesse, finalmente, Mozart, que todos desprezavam, a quem apontavam, rindo, com o dedo, um lugar abaixo do primeiro degrau da escada. (GERSÃO, 1999, p.10-11).

Em síntese, o desejo da consagração, do reconhecimento de Mozart como o padrão de beleza musical, está representado na imagem dela, ainda criança, rezando por esse compositor. O leitor, então, poderá perceber que há, nesse instante, uma disputa entre valores ético e estéticos divergentes.

Mas a música não está presente somente na relação de Júlia e Octávio. A protagonista vive em um ambiente em que todas as pessoas convivem com essa arte, em maior ou em menor grau. Logo, imersa no restrito universo de seu lar, onde a música é o parâmetro para se estabelecerem valores estéticos, comportamentais ou sociais, Mozart parece ter sido, para ela, um referencial basilar.

No início da narrativa, Júlia, que está saindo da infância, busca uma "verdade", um sentido para sua vida. No decorrer da história, ela ingressa na adolescência e se lança, ainda com credulidade, na busca por respostas definitivas para suas inquietações e perplexidades diante da vida. Então, a cada experiência vivenciada, tal verdade é subitamente encontrada e subitamente perdida.

Mozart é a primeira verdade encontrada. Na sua concepção, ele é insuperável, pois surpreende o ouvinte com sua liberdade criadora e sua possibilidade de improvisação ao piano. Em contrapartida, Beethoven apresenta um sistema de notas mais previsível, organizado, representando, assim, o sistema estabelecido por tio Octávio como correto.

\subsection{O compositor Mozart}

O gênio de Wolfgang Amadeus Mozart (Johannes Crysosomus Wolfgang Gottlieb) desabrochou na cidade de Salzburgo, a 27 de janeiro de 1756. Nasceu em ambiente favorável à música, pois seu pai - Leopoldo Mozart - era um homem instruído e exercia funções musicais na corte do arcebispo de Salzburgo. 
Atentando para alguns dados biográficos de Mozart, é possível ver certas semelhanças entre o seu ambiente familiar e o de Júlia.

Segundo o biografo Filho Caldeira,

Muito correto na ética individual e profissional, metódico e severo, Leopoldo submeteu o pequeno Wolfgang à disciplina de trabalho necessária para o pleno desenvolvimento daquilo que desde logo lhe pareceu ser mais do que talento: um gênio autêntico [...]. (p.67)

Mozart, desde criança, foi submetido a muitas horas de treinamento musical para desenvolver suas habilidades. Da mesma forma, Tio Octávio, ao perceber, espantado, o talento musical de Júlia, tenta fazê-la treinar, também, horas e horas para aprimorar sua técnica musical. No trecho a seguir, tio Octávio descobre o talento musical de Júlia:

Fora numa dessas ocasiões em que ambos tocavam, anos atrás, que tudo começara para ela, Júlia: Depois da trabalhosa exibição dos tios, ela sentara-se sobre os calcanhares, de joelhos no banco do piano porque sentada não chegaria ao teclado, e tocara a melodia do tango Camiñito. Os tio tinham-na olhado como se vissem uma assombração. De tal modo que ela se apressara a sair do banco e subira para o sofá, enterrando as mãos nos bolsos do vestido, disposta a esquecer o incidente.

Mas os tios não pareciam dispostos a esquecer. Mandaram-na tocar uma e outra, deram estalos com a língua, fizeram grandes silêncios, ficaram a olhar um para o outro e para ela. (GERSÃO, 1999, p.24).

A partir da descoberta do talento musical de Júlia, tio Octávio inicia as lições de piano para Júlia, a fim de desenvolver seu gênio musical:

[...] no dia seguinte recomeçou, com o tio a ensinar-lhe as notas: escreviam-se na pauta, e eram iguais às do piano: assim. $\mathrm{E}$ os dedos mudavam-se passando o polegar debaixo do maior, curvando em arco. Duas ou mais notas juntas formavam um acorde, os dedos 
numeravam-se de primeiro a quinto, e havia sequências de notas que se chamavam escalas.

Agora tu, dizia o tio, e ela repetia o que ele tocara. (GERSÃO, 1999, p.24-25).

No entanto, apesar de apresentar um dom musical promissor, após Júlia assistir à audição de Ireninha, sua amiga, e verificar a falta de atenção das pessoas à música executada por ela, bem como a formalidade ali instituída por meio das roupas e gestos que Ireninha tinha de fazer para o público, Júlia decide se proteger desse mundo hipócrita, ou seja, da "falsa" atenção do público às execuções musicais e, a partir de então, começa a errar, propositalmente, na execução das peças, até tio Octávio desistir de seu propósito em relação a ela. Abaixo, um fragmento que apresenta o medo de Júlia de se tornar uma Ireninha:

O terror de ser como Ireninha ocorreu-lhe. O terror de a mandarem treinar escalas, tocar para as visitas, fazer vênias (sic) num palco debaixo de salvas de palmas como explosões de metralhadoras.

Não disse mais nada, mas a partir daí começou a tomar cuidado. Nunca repetia, por exemplo, até o fim uma melodia que o tio Octávio acabasse de tocar, mesmo que a tivesse decorado logo. Ouvira dizer que fora assim que Ireninha fora descoberta: por uma grande facilidade em decorar. [...] (GERSÃO, 1999, p.28).

Como se vê pela biografia de Mozart e pela vida de Júlia, há uma semelhança entre ambos em dois aspectos. Além do treinamento musical precoce e rigoroso proporcionado pelo tio Octávio, no caso de Júlia, e, no caso de Mozart, por Leopoldo, seu pai, nenhum dos dois aceita submeter-se a um mercado musical. Mozart decide não compor músicas para agradar a aristocracia, mas sim músicas que expressassem sentimentos profundamente guardados. Obviamente, tal decisão teve um preço. A popularidade de Mozart na corte europeia acaba sofrendo uma queda, como afirmam os biógrafos Massin \& Jean (1997): 
O preço desta liberdade era de certo modo previsível: Mozart deixou de ser o homem da moda de Viena. Os colegas e os críticos começaram a ter atitudes reticentes ou de desaprovação que se foram acentuando e dando um tom para um público que já não mais se comprimia para assistir aos concertos do compositor-virtuose. (p. 576).

Após grande período de produção encomendada para agradar a um determinado público, como a corte ou a maçonaria, Mozart resolve produzir músicas com uma expressão mais livre e pessoal. Sua música não expressa tranquilidade, mas sim inquietude, uma angústia íntima que somente um ouvido atento e sensível seria capaz de perceber.

Além da semelhança quanto à relação musical, Júlia, tal como Mozart, tinha uma avidez por aprender tudo, em especial a matemática. Ela apresenta-se como uma garota curiosa, que busca entender, primeiramente, as relações sociais do seu universo doméstico, o mundo, a formação do universo e certas teorias filosóficas que alguns professores lhe ensinavam na escola. Pensa sobre as opiniões de tio Octávio, com sua insistente defesa de Beethoven em vez de Mozart, e acaba, por meio de seu amadurecimento, utilizando-se da linguagem racional, em especial da matemática, para compreender a música e o cosmos.

Nesse mesmo sentido, Massin \& Jean (1997) assim descrevem Mozart:

Wolfgang [...] era um lindo menino, deliciosamente emotivo e terno, em que uma docilidade sempre atenta aliava-se a uma natural espontaneidade. Queria aprender tudo (como, por exemplo, matemática) e gostava de contar para si próprio histórias saídas de sua fervilhante imaginação. (p.568)

Assim como Júlia se espelha na experiência de Ireninha para "intuir" o que não quer para si, de modo semelhante revela Mozart a intimidade de sua relação com a música: "Se eu toco ou se executam alguma composição minha é como se as mesas e as cadeiras fossem os únicos ouvintes presentes." (MASSIN \& JEAN, 1997, p.573). A 
experiência frustrante de apresentação perante o público é relatada tanto em $O s$ Teclados quanto na biografia de Mozart, que, com apenas seis anos (de 1762 a 1768), viajou pela Europa para se apresentar nas cortes de Munique, Viena, Bruxelas, Paris, Londres, Zurique etc. Mas foi na Itália, já por volta dos quatorze anos, que Mozart teria seu maior aprendizado: "O maior ensinamento que Mozart recebeu da Itália foi a revelação de si mesmo, tanto assim que italianizou o último de seus prenomes, Gottlieb (em latim, Theophilus), para Amadeo ou Amadeus." (MASSIN \& JEAN, 1997, p.569).

Essa revelação de si, uma espécie de epifania, vai sendo alimentada pelo confronto entre o desejo do compositor e a expectativa da sociedade, que levou Mozart a um "surto criativo", em que produziu dezenas de obras, dentre elas a ímpar A Flauta Mágica. Esta foi a música que inspirou muitos escritores, como Goethe e Lessing. Mozart cresce e descobre que o mundo é cruel, cheio de armadilhas e que é preciso aprender a viver nesse jogo social a que se está submetido. Nesse sentido, ele se questionava sempre sobre quem era: "Quem sou eu? Em Salzburg não sei quem sou eu, eu sou tudo e também muitas vezes nada. Eu não peço tanto, mas tão pouco assim também não: basta-me ser somente alguma coisa. Mas que seja somente alguma coisa" (MASSIN \& JEAN, 1997, p.570).

Júlia também quer compreender a si mesma. Ela está em um processo de aprendizagem, compõe-se como sujeito a partir da observação das pessoas ao seu redor, como tio Octávio, tio Eurico, tia Isaura, Armênia, e da tentativa de convívio com elas. Através desse olhar, Júlia também tenta responder à pergunta: “quem sou eu?".

Guardadas as devidas proporções nesse espelhamento que a narrativa sugere, Júlia e Mozart, a cada momento de suas trajetórias, pensam ter encontrado o grande "sentido" para a vida, a grande "verdade" sobre a existência humana. No decorrer de sua vida, Mozart, vai transferindo esta "verdade" para outras esferas, ora projetando-a em um modelo musical, ora em uma pessoa, ora na espiritualidade maçônica. De modo semelhante, Júlia pensa, a princípio, que a verdade está em Mozart, e por decorrência no teclado, na música; depois, na filosofia (Kepler e Platão) e, por fim, na matemática. Mas acaba por aprender que a verdade é essencialmente mutável, pessoalmente construída a cada fase de vida que o ser humano estiver vivendo.

Dizem os biógrafos de Mozart que, no fim de sua vida, estava desesperado por terminar um Réquiem ${ }^{3}$, vivendo por seis semanas sob o impulso da criação, embora seu

\footnotetext{
${ }^{3}$ Réquiem- composição para acompanhamento de funeral . (PLATZER, Frédéric. Compêndio de Música, Lisboa: Edições 70.).
} 
estado de saúde só piorasse. Segundo Massin \& Jean (1997), "No últimos dias de agonia, [...] voltou seu pensamento: todas as noites, mentalmente, ele acompanhava, compasso por compasso, o desenrolar da representação no teatro". (p.581)

A protagonista d'Os Teclados, tinha uma aptidão para memorizar as músicas que produzia, bem como as que lia, executando mentalmente as partituras. Essa habilidade era mozartiana, pois o compositor Mozart também tocava mentalmente. No trecho a seguir evidencia-se a mente prodigiosa de Mozart: “Terminadas, só levarei as minhas sonatas; as duas aberturas e a sinfonia concertante foram compradas por Le Gros. Ele pensa ser o único possuidor delas, mas não é exato: tenho-as frescas na cabeça e assim que chegar, escrevê-las-ei." (CALDEIRA FILHO, p.74).

Como se vê, as experiências de Mozart projetam-se, no plano da narrativa, nas vivências de Júlia. Ambos, Mozart e Júlia, apresentam diversos elementos em comum, além de ele metaforizar, na narrativa, o ideal ético-estético de Júlia. Ou seja, afora esse desejo estético de liberdade ao tocar e ao ouvir, as pressões sofridas pelo compositor no sentido de produzir uma música que agradasse ao "mercado" cultural de sua época e ainda a recusa ao condicionamento social das audições musicais também podem ser vistas no percurso de formação ética da protagonista.

Júlia demonstra ser uma jovem quieta e tranquila, todavia, dentro de si se esconde uma menina ansiosa para compreender a si e ao mundo. Essa aparente tranquilidade pode ser comparada à música composta por Mozart: reconhecido como compositor de uma música alegre e sublime, ele, ao mesmo tempo, surpreende seus ouvintes com notas que não estavam "previstas" em suas melodias, procedimento que os introduz em uma sequência musical melancólica, que evoca as composições do Romantismo.

Assim, em razão dessas semelhanças, pode-se dizer que Mozart e Júlia, em $O s$ Teclados, formam uma unidade interpretativa. Suas biografias se cruzam, de certo modo, para dar o "tom" de leitura desta obra de Teolinda Gersão. 


\subsection{Beethoven - "o poeta dos sons"}

Como já foi dito, além de Mozart, a narrativa também apresenta Beethoven, compositor romântico, paradigma defendido e apreciado por tio Octávio.

Ludwig van Beethoven nasceu no dia 16 de dezembro de 1770, em Bonn. Como o avô e o pai, Beethoven foi destinado, desde a primeira infância, a tornar-se músico a serviço da predileção do ouvinte. Recebeu uma severa educação musical: o próprio pai era o professor e o forçava a estudar horas e horas ao piano, até mesmo durante as madrugadas.

Beethoven sempre foi cercado de dificuldades financeiras em sua família, mas foi a surdez, percebida em 1797, a grande luta enfrentada pelo compositor. Escreveram os biógrafos Massin e Jean (1997) sobre a surdez de Beethoven: "Um músico surdo: o fato é que essa tragédia excepcional não contribuiu pouco para popularizar, para fazer com que Beethoven fosse lamentado (talvez um pouco demais), amado e admirado, mais que qualquer outro compositor, por toda a posteridade." (p.604).

Talvez seja este o ponto da biografia de Beethoven que mais convenha à imagem de tio Octávio, homem também prejudicado pela surdez, que defende o compositor como o maior de todos os tempos. No caso desse tio, não se trata da surdez apresentada por Beethoven, ou seja, de ordem fisiológica, mas, ao contrário, de uma "surdez psicológica”. Tio Octávio não ouve nada nem ninguém, apenas ordena. Quando precisa ouvir, interrompe o silêncio com gritos e murros na mesa, provocando o medo de todos ao seu redor. Até a música de Beethoven, tão admirada e defendida por ele, não passa de música de fundo para suas sonecas no sofá - ou seja, talvez, de fato, nem a Beethoven tio Octávio ouça realmente.

Tanto a surdez de Beethoven quanto a de tio Octávio provocam um desequilíbrio nos respectivos lares. As pessoas com quem ambos precisam conviver sofrem as agressões verbais e até físicas de suas personalidades. Em Os Teclados, Tio Octávio metaforiza o opressor que, pela surdez psicológica, não permite aos outros o estabelecimento de um diálogo. Por isso, na casa em que Júlia vive, o silêncio se traduz em uma forma de censura. Segundo Orlandi (2007), em seu livro As formas do silêncio:

A censura [...] é a interdição da inscrição do sujeito em formações discursivas determinadas, isto é, proíbem-se certos sentidos porque se 
impede o sujeito de ocupar certos lugares, certas posições. Se se considera que o dizível define-se pelo conjunto de formações discursivas em suas relações, a censura intervém a cada vez que se impede o sujeito de circular em certas regiões determinadas pelas suas diferentes posições. Como a identidade é um movimento, afeta-se assim esse movimento. Desse modo, impede-se que o sujeito, na relação com o dizível, identifique-se com certas regiões do dizer pelas quais ele se representa como (socialmente) responsável, como autor. (p. 104).

Ou seja, a censura, no contexto do microcosmo familiar de Júlia, está projetada nas agressões verbais de tio Octávio, em seu comportamento agressivo com tio Eurico, tia Isaura e nas aulas de música para Júlia. Desse modo, ninguém que convive com ele consegue expressar sua opinião de forma tranquila e verdadeira, pois, se o fizer, terá de enfrentá-lo. Portanto, é o silêncio que impera como censura e também como meio de protesto, como faz Júlia ao rezar por Mozart. O fragmento abaixo ilustra esse silêncio de Júlia ao observar as ações revoltadas de tio Octávio devido à interrupção da audição das músicas de Beethoven:

Nessa época tio Octávio ouvia sinfonias e concertos sentado na poltrona ao canto da janela, arrancando pêlos da orelha e palitando os dentes. Praguejava sempre que alguém inadvertidamente, abria a porta, batia com o punho na mesa de camilha como se tentasse afugentar, pelo barulho, o intruso que entretanto retrocedera rapidamente e desaparecera na profundidade do corredor. [...] Voltava depois em passos nervosos, bufava, enxugava a testa com o lenço ou assoava-se, levantava por fim com cuidado a agulha do gira-discos e voltava a colocá-la no lugar aproximado onde estivera, antes de ter sido interrompido. [...]

Mas ela, na verdade, pouco ouvira. Tinha ficado a ver as borlas das cortinas, que balançavam com tanta força quando ele dava murros na mesa de camilha, e ainda muito tempo depois continuavam a balançar. [...] (GERSÃO, 1999, p.07).

Júlia não ouve as palavras do tio Octávio em defesa de Beethoven, pois estava em silêncio, observando a violência dos murros dele na mesa e dos seus efeitos nas cortinas, que continuavam a balançar por longo tempo. Seus gritos irritavam a sobrinha, principalmente pela injustiça em relação a Mozart. Ela permanece em silêncio e não 
responde às provocações do tio, apenas reza por Mozart. O silêncio da oração de Júlia é uma forma de introspecção, isto é, de meditar sobre a agressão verbal de tio Octávio, sendo esta mesma oração, de certo modo, a resposta dada por Júlia ao seu tio, mesmo que só por meio do silêncio.

Outro aspecto interessante da biografia de Beethoven é a elaboração de algumas sonatas a partir de 1802. Nas composições dessa época, Beethoven revela ser o poeta dos sons e "as formas gramaticais que herdou do 'classicismo' vienense obedecem nessas imposições a uma finalidade expressiva que não era a de comprazer ou encantar, mas a de levar o ouvinte à descoberta de si, segundo o itinerário de uma meditação." (JEAN e MASSIN, 1997, p. 605).

De certo modo, mesmo sendo às avessas, tio Octávio também leva Júlia à descoberta de si, não propriamente pela execução de suas músicas, mas despertando nela o desejo de defender seus ideais (como a música de Mozart), ou ainda, a recusa de ter sua interpretação manipulada pelo desejo das pessoas (mercado/ouvinte). Talvez por esse motivo, Júlia apelida tio Octávio de tio Oitavo. Levando-se em consideração que uma oitava é a sequência de notas de Dó a $D o ́$, tem-se uma espécie de retorno à mesma nota, porém com alguma modificação, em se tratando da nota musical - uma oitava acima ou abaixo; no caso de Júlia, uma releitura de si mesma, elaborando seus ideais éticos e defendendo-os. A seguir, observa-se o trecho em que Júlia compara tio Octávio a uma oitava musical: "Completamente a salvo, inacessível a todos. Sobretudo ao tio Octávio. De quem agora perdia o medo, e a quem chamava, interiormente oitavo. Um oitavo não era nada, só uma parte pequena - oh, tão pequena - de qualquer coisa. $\mathrm{O}$ tio Oitavo. [...] (GERSÃO, 1999, p. 37)”.

Beethoven ficou conhecido como o compositor das massas, ao contrário de Mozart. Ele cai no gosto popular e passou a ser idolatrado por músicos do mundo inteiro, inclusive contemporâneos, como o grande mestre da música romântica. Assim como esse compositor, Tio Octávio também defende que o músico/intérprete deve tocar para agradar às massas. Disse Tio Octávio: "Mas é o fim de um artista, se não baterem palmas [...]. Ai, dele se não baterem.” (GERSÃO, 1999, p. 27), apontando a importância do público como referencial para a autorrealização do músico. Sendo assim, tocar para agradar a esse público se torna tão importante quanto (ou sinônimo de) uma boa execução. Essa atitude de devoção e submissão ao público, produzindo execuções que lhe agradem, é rejeitada por Júlia, por isso ela finge não saber tocar direito e nega-se a cumprir semelhante papel. 
É interessante e importante que o leitor de Os Teclados apreenda a função de Mozart e Beethoven como simbolização dos valores éticos defendidos, respectivamente, por Júlia e tio Octávio, considerando, para isso, também alguns aspectos biográficos desses compositores para a expansão do reconhecimento do conteúdo semântico das personalidades de tio Octávio e de Júlia ao longo da obra.

\section{3 “As muitas vozes” de Johann Sebastian Bach - “o músico poeta”.}

Enquanto Mozart e Beethoven representam os valores éticos e estéticos de Júlia e tio Octávio, a música de Bach aparece no enredo metaforizando as inter-relações pessoais na casa de Júlia: “As muitas vozes das coisas. Vozes de Bach, jogando umas com as outras, cruzando-se, convergindo, divergindo. Puro jogo, como o do mar e das ondas. Assim o mundo era feito.” (GERSÃO, 1999, p.15).

Júlia analisa as relações de sua casa e conclui que a loucura é o ponto que une todos os seus membros de algum modo e, por conseguinte, tio Eurico não era o único louco entre eles. O "jogo de loucura" existente na casa, onde cada voz (personagem) tenta ocupar seu espaço através da ligação com outra voz, estabelecendo com ela relações de oposição e espelhamento, assemelha-se à estrutura de uma composição musical chamada fuga. No fragmento abaixo, pode-se perceber o jogo das vozes ligando-se umas às outras na ambiência da loucura:

Mas não era louco sozinho, pensou [Júlia]. A loucura era uma roda girando entre uns e outros, ligando-os. A loucura do tio Octávio fechando o tio Eurico, que acabava sempre por fugir, a loucura das chaves deitadas fora, dos cadeados portáteis, das escápulas do lado de fora das portas. A loucura da tia, embalando uma criança gigante que não lhe cabia nos braços e rebentava o telhado e as paredes, a loucura instalada na casa, fazendo-a girar sobre si própria, como um moinho de café. Provavelmente era assim, de um modo ou de outro na maioria das casas?

Os não loucos, ou os que assim se julgavam, descarregavam nos outros a sua própria loucura e julgavam-se a salvo. (GERSÃO, 1999, p. 40). 
Tio Eurico, tia Isaura e tio Octávio - ligados entre si e aos demais - formam a música daquele universo. Uma música permeada de silêncios (de tia Isaura, Armênia, tio Eurico, Júlia) e opressão (por parte de tio Octávio), sendo a loucura o fio condutor, espécie de tema musical dessa fuga doméstica.

A Fuga é a forma musical que melhor representa a música de Bach. A palavra advém do latim fugare (perseguir) e fugere (fugir). As variações incluem: fughetta (uma pequena fuga) e fugato, uma obra ou seção parecendo uma fuga sem, necessariamente, aderir às regras de formação de uma fuga.

Em música, a fuga, nascida no seio do Barroco, é uma composição contrapontística, polifônica e imitativa, de um tema principal, repetido por outras vozes que entram sucessivamente e continuam de maneira entrelaçada. Inicia-se com um tema, declarado por uma das vozes isoladamente. Uma segunda voz entra, então, "cantando" o mesmo tema, mas noutra tonalidade, enquanto a primeira continua desenvolvendo-o com um acompanhamento contrapontístico. As vozes restantes entram, uma a uma, cada uma iniciando com o mesmo tema. O restante da fuga desenvolve o material posterior, utilizando todas as vozes e, usualmente, múltiplas declarações do tema.

Estas técnicas estilísticas todas, típicas de várias músicas de J. S. Bach, das suas invenções, das aberturas, tiveram origem primeiramente na forma musical chamada canônica, que Bach elabora mais ainda, explorando a fuga como a forma de variações sobre o tema: ora varia o tom, o ritmo e, especialmente, a voz, com uso de imitação, assim como com uso de tema retrógrado, de inversão do tema, ora espelha esse tema, modula-o, expande-o, sintetiza-o, ora transpõe-no; utiliza, enfim, ao máximo as demais técnicas da forma de tema e variação na fuga, como se (o próprio nome já indica isso) o compositor estivesse fugindo e perseguindo o tema (perseguindo todas as pequenas partes do tema espalhadas pela música) com cada uma de suas diversas variações.

Transpondo a estrutura musical da fuga para a primeira parte do livro, pode-se conceber a loucura como o universo paralelo de significação em que se estabelece o jogo familiar. Ela é a lógica paralela ao real em que todos tomam parte como peças de um jogo. Tio Eurico pode ser compreendido como a metáfora da loucura, ou seja, desse universo paralelo que sofrerá variações, pois na obra, não há apenas a loucura mental de Eurico, mas também a loucura de tio Octávio em defender somente Beethoven, exigir de Júlia um treinamento exaustivo musical ou trancar tio Eurico no quarto, pois o vê como uma vergonha social. Ou a loucura de tia Isaura, que olha para tio Eurico como 
uma criança, tratando-o como a um bebê; que se submete aos desmandos e maus tratos de tio Octávio. Tal como Júlia, também tia Isaura, acredita ter o mesmo comportamento de tio Eurico em certas situações e teme enlouquecer como ele.

Ainda nesse sentido, tio Eurico também pode ser visto como um "espelho" em que cada personagem, de certo modo, se vê projetada, reconhecendo a própria loucura nos seus silêncios, na opressão que ele sofre, em sua incapacidade de comunicação enfim Eurico, em suas fugas pela cidade, expõe a imagem de um ser humano destruído socialmente. Talvez, por esses motivos Júlia chame tio Eurico de "tio eu" - não metaforizará ele as vozes (os “eus”) que formam o jogo da fuga naquele espaço?

Conclui-se, portanto, que enquanto Mozart e Beethoven carregam em si, na obra, os aspectos dos valores éticos de Júlia e tio Octávio, a música de Bach, especificamente a fuga, metaforiza as diversas vozes que compõem o ambiente na casa de Júlia, tal como é retratado na primeira parte do livro.

Dentre os traços biográficos de Johann Sebastian Bach podem ser vistos alguns elementos que, de algum modo, dialogam com as personagens de Os Teclados. Primeiramente, a identificação com a música: por várias gerações, os Bach haviam sido músicos e já com algum destaque. Bach, ao longo de sua carreira artística, dedicou-se à composição para cravo e violino, muitas com temas religiosos. Também se preocupou com correntes artísticas de seu tempo, chegando a travar uma luta artística, em 1717, com Marchand, célebre organista francês. Um outro detalhe importante é a cegueira, que acomete Bach em meados de $1740^{4}$, e esse pode ser o principal ponto de contato com o universo inscrito em Os Teclados

Não só a estrutura de Bach pode ser reconhecida na casa de Júlia, mas também a cegueira daqueles que lá habitam e não a percebem. Além da loucura (dramatizada nas muitas vozes de Bach), ali prevalece a cegueira de todos (exceto da protagonista): ninguém compreende o fio que os desune nem consegue estabelecer relações de afeto e cooperação uns com os outros.

A estrutura harmônica do livro, abordada no capítulo IV, ainda recorre ao contraponto até o fim do enredo, destacando, posteriormente, outros recursos musicais, como a técnica de retardamento e a polifonia poética, que auxiliam na elaboração musical da obra. Os recursos citados serão explorados detalhadamente no quinto

\footnotetext{
4 "Em 1740, Bach havia sofrido sérias perturbações na vista, consequência do excesso de trabalho em horas inadequadas e talvez do esforço desprendido na juventude ao copiar à luz do luar o álbum [de músicas] do irmão." (CALDEIRA FILHO, p. 47).
} 
capítulo, a partir da análise dos efeitos estéticos na obra Os Teclados, com base nas teorias de Iser e Compagnon.

\subsection{Outras relações músico-sociais}

Os elementos musicais e a fantasia que regula a imaginação infantil de Júlia conduzem o leitor a um universo familiar em que a música é, talvez, a única linguagem que, de algum modo, as personagens conhecem: a autora oferece a Júlia, heroína em processo de aprendizagem, apenas um mundo caótico (sua casa), o piano e a linguagem musical para construir sua autoconsciência e constituir-se como sujeito.

O mundo caótico é formado por Tio Octávio, chefe do lar, que ostenta uma imagem conservadora sobre a cultura e a educação. Ele elege Beethoven, como se falou, como paradigma obrigatório a ser seguido, principalmente por Júlia. Tia Isaura é a mulher submissa, que vê na música uma forma auxiliar na conquista da sobrevivência social,pois lhe garante a possibilidade de acesso ao casamento. Para Isaura, ao tocar, a mulher se coloca naturalmente em evidência, pois, no momento em que estiver ao piano, todas as atenções estarão voltadas para ela enquanto executante. Portanto, tocar piano é uma forma de colocar-se socialmente em evidência e chamar a atenção de algum possível pretendente. Porém, uma vez conquistado o casamento, a música tornarse-ia um fardo para a esposa, que agora mal suportava tocar junto com Tio Octávio.

Nesse lar caótico, o silêncio caminha paralelo à música. Armênia e Isaura são meio surdas, bem como Tio Eurico, o louco, que não ouve ninguém e vive em um mundo unicamente seu, isolado e ignorante das regras sociais da casa. Somente a linguagem musical adentra o mundo de Eurico. Entretanto, como ele não domina o discurso, pois não fala, passa a viver em um mundo de silêncios, apenas se comunicando por meio das batidas de uma colher de pau nos móveis, tentando acompanhar o ritmo dos tangos executados por Júlia.

Ao longo da narrativa, Júlia cresce, e ora o narrador, ora ela própria vão apresentando aos leitores os professores, que metaforizam paradigmas de comportamento.

Os professores estão, aparentemente, separados em dois grandes grupos: aqueles que veem a arte como mercadoria e, portanto, valorizam a venda de apostilas, roupas 
bonitas no dia da audição pública, dentre outras futilidades; e um outro grupo, representado pelos que apreciam a música como meio de transcendência da alma.

O professor Mendonça é exemplo do primeiro grupo. Ele organiza as apostilas musicais colocando seu nome em grande destaque nas capas, como se ele fosse mais importante que os verdadeiros compositores. O objetivo de Mendonça é atingir o mercado consumidor. Para ele, a música e o ensino musical são mercadorias. No trecho a seguir, Júlia reflete sobre as ações desse professor, interessado em destacar seu nome nas apostilas (a ponto de a grafia do nome do professor aparecer (ironicamente) em letra maiúscula):

[...] E finalmente em letras tão inchadas que não havia certamente para eles caracteres gráficos já prontos e deviam ter sido desenhadas a trincha: SEVERIANO MENDONÇA. E em cima do nome, para que não restassem dúvidas, a fotografia. Dedilhava tão bem, revia tão bem, Mozart, Bach, Chopin, Beethoven, Schubert, nada eram, o importante era terem sido DEDILHADOS POR: SEVERIANO MENDONÇA. (GERSÃO, 1999, p. 84).

Além de Mendonça, a narrativa também apresenta Madame Ortega, professora muito exigente, não só em relação à execução das partituras, mas também em relação à postura e apresentação física de seus alunos no dia da audição, por isso se preocupa com que eles cumprimentem devidamente o público ou se vistam de modo elegante no dia da audição. Ela, de certo modo, simbolizaria os rituais sociais estabelecidos a partir de uma apresentação musical, mais ou menos como Tia Isaura pensava.

Palrinha, outro professor de música, é a contrapartida de ambos: lecionava música com liberdade, não via na música um objeto de mercado a ser vendido, mas sim uma forma de manter sua vida por meio da arte, permitindo que as pessoas se transformassem através do piano. Mas, Palrinha, apesar desse idealismo, também precisava lecionar para pessoas que não tinham a sua mesma visão sobre a arte. Afinal, são esses alunos que compõem seu orçamento mensal. Logo, a narrativa expõe um dilema entre o mercado e o ideal do ensino da arte musical. 
A cada personagem apresentada, novos paradigmas de condutas ou sentidos de vida estão sendo expostos diante do leitor. O ideal e o real de música, de conduta como menina, de professor, de leitor etc.

\subsection{A multiplicidade de teclados}

Quando o leitor lê o título do livro, assim no plural, ele provavelmente se indaga: por que "Os Teclados"? No decorrer da narrativa, ele percebe que há várias referências a teclados, tais como o teclado de papel, o teclado do piano e o teclado do computador. Cada um deles metaforiza uma circunstância vivenciada por Júlia, como se fossem momentos que auxiliam na constituição da protagonista como sujeito.

Como já foi apresentado no início deste capítulo, Júlia não suporta os paradigmas estabelecidos por tio Octávio e não deseja para si a apreensão e a pressão sofridas por sua amiga Ireninha em sua audição pública. Por isso, opta por tocar no silêncio, ou seja, fazer para si um teclado de papel. Esta seria a primeira metáfora que contribuiria para explicar o uso do plural no título. Em uma casa em que a censura reina como modo operante na figura de tio Octávio, restam a Júlia poucas formas de protesto e todas elas passam pelo silêncio: a prece, no início da narrativa, posteriormente o teclado de papel, depois, a clavinova onde se tocava com os auscultadores e, por fim, o piano em uma sala vazia, onde se tocava sem público.

O teclado de papel, além de metaforizar um protesto silencioso de Júlia em relação aos paradigmas ético-musicais de tio Octávio, também poderia simbolizar o isolamento, a solidão (benéfica) da criação artística.

$\mathrm{Na}$ trama, criar, de forma ambivalente, um teclado de papel pode ser visto como a metáfora da produção de sua própria história, porém elaborada por outro teclado, o do computador, e impressa em papel, na materialidade do livro. Esta é a segunda metáfora, pois o teclado do computador cria um diálogo entre a criatura (Júlia) e sua criadora, a escritora (na narrativa Helena Estevão, possível alter-ego de Teolinda Gersão). Já o teclado do piano é a grande metáfora da obra, uma vez que é por meio dele que a linguagem poético-musical se desenvolve, auxiliando Júlia na construção de seus paradigmas. 
O teclado é um espaço simbólico dentro da narrativa. Um espaço ora opressor, pois impõe formas de comportamento pré-estabelecidos por alguém, ora libertador, pois permite à Júlia estabelecer seus próprios paradigmas, nem que para isso seja preciso reproduzir o teclado em um pedaço de papel.

A linguagem musical é uma importante forma de comunicação estabelecida dentro da casa. Tio Octávio, tia Isaura, Tio Eurico e Júlia se comunicam por meio de processos e comportamentos musicais. A música não é só feita de som, mas também de silêncios (as chamadas pausas): Tio Eurico, Tia Isaura e Armênia não ouvem uns aos outros, vivem no mundo do silêncio, ou seja, da pausa, assim como Júlia quando toca em seu piano de papel ou apenas olhando as partituras. Não há sons, apenas interiorização da música - uma espécie de relação entre o ser que ali ouve sua música, solitariamente, e a arte musical. Tio Octávio ouve Beethoven como um ritual, deseja o silêncio de todos à sua volta para apreciar a música de seu ídolo; no entanto, impõe a pausa, ou seja, o silêncio do mundo para si, sem estabelecer uma relação de comunicação com nenhum membro de sua família.

Para Júlia, a música é uma linguagem transcendente e perigosa. Nela estão projetados seus paradigmas de comportamento e verdade, principalmente na música de Mozart, por meio da qual ela busca constituir-se como sujeito. Com medo de se perder na infinita possibilidade que o teclado apresenta e não encontrar o sentido que está procurando, a garota fecha-se em si mesma, tocando em um teclado de papel, que só pode ser ouvido por ela e não se apresenta, portanto, ao julgamento do público.

Ao entrar em contato com o artigo de jornal com a entrevista com a escritora Helena Estevão, desencadeia-se na protagonista a percepção da mutabilidade do sentido da vida, pois os paradigmas assimilados são, a cada momento, transformados a partir das experiências individuais. A partir desse episódio (em que ela lê o artigo), parece que a narrativa toma um outro rumo, e as atitudes da protagonista demonstram um nível maior de consciência, que se reflete na aceleração do movimento dos seus pensamentos, percorridos por dúvidas, incertezas e ansiedades.

O fato de Júlia treinar em um teclado de papel é um modo de se proteger de tio Octávio e suas ideias de transformá-la em um gênio musical, seguindo as tendências de um suposto mercado. Isto é, a música interpretada por Júlia é ouvida apenas dentro dela, como as preces que ela fazia no início do enredo.

Este teclado de papel é substituído, na narrativa, pelos auscultadores ligados à clavinova. Ou seja, a tecnologia já existente na casa de Lúcia, amiga de Júlia, faz com 
que ela não necessite do silêncio do teclado de papel, uma vez que pode tocar sem ninguém ouvir sua execução: de certo modo, a música continua sendo interpretada apenas internamente, já que somente a protagonista a ouve. No trecho abaixo, Júlia mostra-se feliz pela descoberta deste aparelho que lhe permitiria tocar sem ser ouvida:

Porque a seguir teve uma surpresa: Lúcia abriu a porta do escritório e mostrou-lhe a clavinova. Tocava com os auscultadores, explicou, para não incomodar a mãe, que tinha dores de cabeça muitas vezes. [...]

Além do mais, riu, os auscultadores são óptimos, ninguém sabe se estou a estudar ou não.

Existia portanto um milagre assim? Bastava uma cavilha para esconder o som, fazê-lo apenas seu?

Experimenta, disse Lúcia, divertida de a [Júlia] ver tão deslumbrada. (GERSÃO, 1999, p.64-65).

Além desse "milagre", como chamou Júlia, os auscultadores proporcionam-lhe uma grande descoberta; pode-se dizer que, num novo momento epifânico, ela concebe que a interpretação musical envolve o intérprete e a obra, a aprovação do público não sendo mais uma necessidade, como pensava tio Octávio. Ao se libertar do público, Júlia crê na transformação do ser através dessa relação entre arte e intérprete.

Por isso, no fim da narrativa, ela toca na ausência do público. Como consegue resolver a incógnita que percorria seu trajeto de constituição como sujeito, ou seja, sua relação com a arte, não é preciso silenciar sua música, pois, naquele momento, ela concebe a ideia de tocar para uma plateia vazia, reafirmando, de certo modo, o paradigma ético apresentando através da figura de Mozart, isto é, a música fluiria a partir da interpretação do músico e não dependeria da opinião do público, segundo a protagonista.

Essa concepção nasce a partir do "milagre" da existência dos auscultadores e da reflexão de Júlia sobre sua ida ao circo com Ireninha, onde ela assistiu à apresentação de uma trapezista. A seguir, a análise desse episódio e de suas repercussões na aprendizagem da protagonista. 


\subsection{A trapezista - senhorita Maciel}

Outra metáfora que exemplifica a mudança no sentido da vida de Júlia é a aparição da trapezista. Acompanhando Ireninha a uma apresentação circense, ambas veem uma trapezista chamada senhorita Maciel executar seu número. No início da apresentação, Júlia crê que seu olhar é o responsável pela segurança da artista que, portanto, não poderia deixar de olhar a moça se equilibrando na corda, pois só o seu olhar a impediria de cair. Esse sentimento de apreensão da personagem irá ser compreendido e repensado após várias outras experiências que ela ainda viverá.

Uma delas é a experiência quase epifânica com a clavinova e os auscultadores, quando Júlia tem, novamente, a possibilidade de ouvir o som que executa, sem precisar elaborá-lo unicamente dentro de sua mente. O fato de tocar e ouvir suas partituras, sem ninguém a ouvir, pois os auscultadores isolam sua interpretação do mundo externo, significa algo similar à experiência com o teclado de papel, porém agora com a audição real das notas executadas. Essa experiência lhe traz um amadurecimento que o leitor capta a partir da descrição da facilidade em tocar determinadas músicas que, antigamente, eram complexas para ela:

Tocar sem ninguém ouvir era uma experiência exaltante. A clavinova não tinha exatamente o som do piano, mas aproximava-se, e de qualquer modo oferecia-lhe a liberdade total. Tocava durante horas, sem dar conta: Interessava-se outra vez por partituras que abandonara, por vezes havia anos, e agora voltava a descobrir e a surpreendiam porque as entendia de outro modo. (GERSÃO, 1999, p. 65)

A partir desse amadurecimento, Júlia relembra a experiência vivida no circo, quando, tal qual tio Octávio, pensava que o equilíbrio da trapezista dependesse de seu olhar enquanto público. Isto é, assim como Tio Octávio acreditava na importância das palmas, ela creditava ao olhar do público o poder de "suportar" o equilíbrio do artista.

Entretanto, após a experiência da clavinova e dos auscultadores, ela crê que a relação artística é internalizada, dando-se, única e exclusivamente, entre a obra de arte e seu intérprete. No fragmento a seguir, o narrador apresenta os pensamentos de Júlia nesse seu instante de amadurecimento: 
Uma parte do trabalho era inconsciente, pensava, crescia de noite dentro dela. De repente conseguia sem esforço o que antes lhe parecera impossível. O momento em que, como se tivesse ganhado balanço, oscilando para cá e para lá sobre uma corda tensa, se lançava sem rede. Como fizera (tinha certeza) o autor da partitura. Ela refazia o seu vôo. Experimentando a mesma sensação embriagante de soltarse.

Não era o olhar do público que segurava a trapezista, há muito que sabia. [...] Tudo se passava unicamente entre a mulher e a corda do baloiço onde oscilava. A vida ou a morte dependiam do acordo entre ambos: da harmonia entre o corpo e a corda. (GERSÃO, 1999, p. 66)

Assim, Júlia compreende tanto a intimidade da interação entre a corda e a trapezista quanto seu papel como espectadora naquele instante: ela é impotente diante dos riscos enfrentados pela senhorita Maciel.

A reação imediata do público não é o que sustém nem orienta a execução, tampouco a criação da obra de arte, pois a execução musical pode ser fácil algumas vezes, difícil outras. Por isso, enfrentar o teclado era um risco constante.

Assim como escrever também é um risco constante. Nas palavras de Helena Estevão, a criação artística: "Era uma tarefa desmedida, mas também humilde e perigosa, porque se trabalhava sem rede." (GERSÃO, 1999, p. 52). É uma constante o risco da criação literária e da ausência da certeza da reação do leitor em relação à sua criação.

Logo, a metáfora da trapezista ajuda o leitor a compreender a constituição de um outro sujeito ético, além de Júlia, isto é, o “eu-leitor”. O Mito de Er, introduzido a Júlia pelo professor de Matemática também auxiliará no entendimento da constituição ética da protagonista.

\subsection{O mito de Er e o Mito das sereias}

Em uma conversa num café à beira do rio, o professor de matemática Rogério Souto apresenta a Júlia o Mito de Er, de Platão. Ela, agora adolescente, manifesta tanto 
interesse pelos diferentes mitos que narram a formação do Cosmo quanto sente atração pelo professor, a ponto de, no decorrer da conversa, tentar discretamente seduzi-lo.

É nesse contexto que o narrador, por meio do discurso indireto, cita o Mito de Er e mistura ao enredo a narrativa desse mito, enfatizando o trecho em que as sereias aparecem. Enquanto o narrador conta a história de Júlia no bar, paralelamente, entre parênteses, ele estabelece um jogo alegórico citando o trecho do Mito de Er que fala das sereias. Segue abaixo a sequência narrativa do mito de Er, no trecho que se refere às sereias:

[...] em cada um dos oito círculos dos planetas havia uma sereia em harmonia com as três Moiras.

(Ela caindo dos mundos, de esfera em esfera, presa por um pé. Descendo vertiginosamente através dos planetas. Em cada um uma sereia olhando.)

(Em cada planeta uma sereia olhando com o rosto dela própria.)

(As sereias cantavam em harmonia com o destino. Que era sempre o mais forte.)

(Elas penteavam os longos cabelos, sentadas nos rochedos. As sereias. E cantavam.) (GERSÃO, 1999, p.77-79).

O mito é apenas citado no enredo: "No mito de Er Platão descrevia a estrutura do universo" (GERSÃO, 1999, p.76). No entanto, detendo-se nessa alegoria platônica, o leitor encontrará um discurso sobre o universo e as almas e sobre o papel da arte na formação do ser. Para compreender melhor a metáfora elaborada nesse trecho de $O s$ Teclados, convém retomar os mitos platônicos da caverna e de Er, para depois, estabelecer relação entre tais mitos, as sereias e a aprendizagem de Júlia por meio da arte musical.

Platão, filósofo grego, em A República, narra o Mito da Caverna, que aborda o movimento do homem em busca do conhecimento. O mito descreve uma caverna separada do mundo externo por um alto muro, cuja entrada permite a passagem da luz exterior. Seres humanos, geração após geração, vivem ali acorrentados. Sem possibilidade de movimento ou locomoção, são forçados a olhar somente para a parede do fundo da caverna, sem nunca verem o mundo exterior nem a luz do sol. Acima do muro, um feixe de luz exterior ilumina o interior da caverna, fazendo com que as coisas do mundo exterior sejam projetadas como sombras nas paredes do fundo. Os 
prisioneiros acreditam que essas sombras são as próprias coisas externas e que as imagens projetadas são os seres vivos, o mundo real. Um dos prisioneiros, tomado pela curiosidade, decide fugir da caverna. Fabrica um instrumento com o qual quebra as correntes e escala o muro. Sai da caverna e, no primeiro instante, com a luminosidade do sol, fica totalmente cego. Pouco a pouco, habitua-se à luz e começa a ver o mundo. Encanta-se, deslumbra-se, tem a felicidade de, finalmente, ver as próprias coisas como verdadeiramente são, descobrindo que, em sua prisão, viu apenas sombras. Esse homem, encantado pelo que viu, deseja voltar à caverna, contar tudo para os outros e libertá-los. No entanto, é assaltado pelo medo. No que os prisioneiros iriam acreditar? Retornar à caverna não seria tarefa fácil. Assim como a subida foi penosa, porque o caminho era íngreme e a luz ofuscante, também o retorno será penoso, pois será preciso habituar-se novamente às trevas, o que é muito mais difícil do que se habituar à luz. De volta à caverna, desabituado às trevas, o prisioneiro desajeitado, não saberá mover-se nem falar de modo compreensível para os outros, não será acreditado por eles e correrá o risco de ser morto pelos que jamais abandonaram a caverna.

Segundo a filósofa Marilena Chauí, em seu artigo O Mito da Caverna e o Mito da Reminiscência,

O Mito da Caverna apresenta a dialética como movimento ascendente de libertação do nosso olhar que nos libera da cegueira para vermos a luz das ideias. Mas descreve também o retorno do prisioneiro para ensinar aos que permaneceram na caverna como sair dela. Há, assim, dois movimentos: o de ascensão (a dialética ascendente), que vai da imagem à crença ou opinião, desta para a matemática e desta para a intuição intelectual e à ciência; e o de descensão (a dialética descendente), que consiste em praticar com outros o trabalho para subir até a essência e a ideia. Aquele que contemplou as ideias no mundo inteligível desce aos que ainda não as contemplaram para ensinar-lhes o caminho. Por isso, desde Mênon, Platão dissera que não é possível ensinar o que são as coisas, mas apenas ensinar a procurálas. (p. 02)

Em Os Teclados, o professor Rogério Souto, por meio da "descensão ou dialética descendente", auxilia Júlia a realizar o movimento de "ascensão ou dialética ascendente”, ensinando a ela os mitos que explicariam a formação do universo. Ele cita 
Pitágoras, Platão e Kepler, tentando, através do pensamento científico e matemático, levar Júlia a refletir sobre o cosmo.

A partir da alegoria da caverna apresentada acima, Platão estabelece que há dois mundos: o inteligível e o sensível. O mundo sensível é aquele que pode ser percebido pelos nossos sentidos, ou seja, é o mundo das sombras projetado na parede da caverna, pois, segundo Platão, tudo o que se vê no mundo é uma cópia da essência verdadeira que se encontra no mundo inteligível, o chamado mundo das ideias, onde estaria o verdadeiro conhecimento. Conhecimento esse buscado, principalmente, pelos filósofos. Em Os Teclados, o professor de matemática Rogério Souto pode ser comparado ao homem que consegue fugir da caverna, vê o que é real e retorna para apontar aos outros a verdade sobre a vida.

Todavia, o Mito da Caverna parece não abarcar toda a explicação sobre a necessidade do homem pela busca do conhecimento. Platão escreve um segundo texto, o Mito de Er citado no trecho a seguir d'Os Teclados: “(...) no mito de Er Platão descrevia a estrutura do universo" (GERSÃO, 1999, p.76). Esse trecho refere-se ao Mito de Er ou da Reminiscência de Platão. A partir do Mito da Caverna surgem alguns questionamentos: como, vivendo dentro da caverna, alguns homens sentem atração pelo mundo das ideias? Como, nunca tendo tido contato com o mundo inteligível, algumas almas o procuram? De onde vem o desejo de sair da caverna? Mais do que isto, como os que sempre viveram na caverna podem supor que exista um mundo fora dela? Para decifrar este enigma, Platão narra o Mito de Er, também conhecido como o Mito da Reminiscência.

O pastor Er, armênio, da Panfília, morto em uma batalha, é conduzido pela deusa até o Reino dos Mortos, para onde, segundo a tradição grega, sempre foram conduzidos os poetas e adivinhos. Lá, ele encontra as almas dos mortos contemplando as ideias. As almas devem reencarnar e, para isso, são levadas para escolher, livremente, a nova vida que desejam ter na Terra. Após a escolha, são conduzidas por uma planície onde correm as águas do rio Lethe (esquecimento). As almas que escolheram uma vida de poder, riqueza, glória, fama ou vida de prazeres, bebem água em grande quantidade, o que as faz esquecer as ideias que contemplaram. As almas dos que escolhem a sabedoria quase não bebem das águas e, por conseguinte, na vida terrena, poderão lembrar-se das ideias que contemplaram e alcançar, nesta vida, o conhecimento verdadeiro. 
Devido à escolha realizada, as almas anseiam ou não pela verdade. A escolha pelo conhecimento se dá àquelas almas em que essa busca despertará um amor profundo pelo saber, porque, vagamente, lembram-se de que já viram o conhecimento verdadeiro e já o tiveram.

No mito de Er, Platão, por meio de uma estrutura dialógica, faz Sócrates dizer que conhecer é lembrar. Tem-se a imagem do filósofo dialético, ou seja, aquele que faz o homem lembrar-se, suscita nos outros a lembrança do verdadeiro, ou ainda, daquilo que está no mundo das ideias. Se já não tivéssemos estado diante da verdade, não só não poderíamos desejá-la como, chegando diante dela, não saberíamos identificá-la, reconhecê-la. Para Platão, alguns homens seriam coautores do conhecimento verdadeiro, desejando sempre encontrá-lo.

Para Platão, tudo aquilo que não representa a verdade, o Mundo das Ideias, pertence às paixões, ao mundo sensível, logo deve ser desprezado, principalmente por aqueles que desejam manter a alma pura sem contato com as imitações. $\mathrm{O}$ artista (pintor e poeta) portanto, é aquele que, por excelência, faz a arte da imitação. Ele vê os objetos do mundo e os pinta, ou canta em poemas e, por conseguinte, realiza a arte de imitar o que, segundo Platão, já é cópia da cópia da imagem do mundo inteligível. Por isso, pintores e poetas são desprezados por Platão, pois, segundo ele, suas artes despertam no homem as paixões e não a razão e, então, sua arte, assim como eles, deve ser desprezada. Apenas as artes que obedecem à moral, à ética podem ser apreciadas. $\mathrm{O}$ homem deve desejar a razão para alcançar o conhecimento verdadeiro, segundo Platão.

Tentando aplicar alguns detalhes da narrativa mítica a Os Teclados, é possível ver que Júlia, a protagonista, está em busca de uma verdade, tenta constituir-se como sujeito a partir da interação com as personagens que fazem parte da sua vida e das teorias apresentadas pelo professor Rogério Souto, bem como a partir das reflexões de Helena Estevão. Essas teorias levam-na a pensar que o sentido da vida é transitório e, por meio, de uma relação dialética, Júlia parece ora estar dentro da caverna, ora estar fora, em contato com o conhecimento.

A partir da intertextualidade entre os mitos platônicos, observa-se a arte como as sombras e as correntes da caverna. Libertar-se dessas amarras levaria o ser a transformar-se e a alcançar o conhecimento através da Razão, da Ética e da Moral. 
Entretanto, no enredo de Os Teclados, a arte é a linguagem pela qual Júlia alcança a Razão, de certo modo, é o Mito de Er às avessas, pois Júlia não se submete simplesmente ao que lhe impõem; ao contrário, ela realiza seu próprio julgamento: assim como estabeleceu que Mozart seria seu paradigma de beleza em vez de Beethoven, ela avalia os mitos e faz sua releitura conforme o universo a que pertence.

Nesse sentido, cabe nesta análise o Mito de Er sartriano, que, de certo modo, inverte as concepções platônicas. Para a análise do Mito de Er segundo Sartre, será utilizado o artigo $O$ mito de Er: Sartre e o platonismo às avessas? De Thana Mara de Souza (2006). Esse artigo buscou apontar "como o mito de Er, descrito no livro X de $A$ República, é reinventado por Sartre em um conto (Er, l'arménien) de modo a modificar a relação entre a estética e a ética." (SOUZA, 2006, p.107).

Segundo Sartre, Er "é agora ele próprio um armênio que vem de uma família que tem um estranho ritual (quebrado apenas pelo pai e o avô de Er): o de morrer e ressuscitar, contando ao povo o que vira no reino dos mortos" (SOUZA, 2006, p.112). Apesar de dialogar com o Er platônico, esta personagem de Sartre vive no mundo contemporâneo e narra a própria história (em Platão, é Sócrates o narrador dos acontecimentos com Er. Além disso, o Er platônico é passivo, assistindo às ações das Moiras [Parcas] como uma testemunha do que acontecia no reino dos mortos).

As diferenças entre os mitos já começam com a descrição dos ambientes. Enquanto na visão de Platão, tem-se um céu limpo e maravilhoso, traduzindo uma sensação de calma e paz, com um Er que tudo vê e nada fala, em Sartre há uma “escuridão, movimentos vertiginosos, medo, angústia e quando, enfim, Er alcança uma certa sensação de maior tranquilidade, a ele é dada uma missão: fazer uma pergunta clara aos deuses" (SOUZA, 2006, p.113).

Enquanto o Er platônico é passivo e observador, o sartriano se mostra ativo, devendo fazer perguntas aos deuses, direcionando-os neste diálogo. E, então, o Er sartriano faz sua pergunta: ele deseja saber o que é o Mal. Para sua surpresa, o titã Briarée dá a primeira resposta, dizendo que o Mal não existe. Essa conversa é entrecortada pelo diálogo entre Prometeu e Ichtyos, no qual se mostra que o Mal e o Bem são julgamentos realizados pelo homem e que, portanto, não existe nem Bem nem Mal no mundo, mas sim pontos de vista diferentes estabelecendo valores morais sobre as coisas. 
Esse é o ponto que nos interessa na referência do Mito de Er em Os Teclados. Er vislumbra que cada pessoa tem a vida que escolhe para si, sendo esta uma escolha consciente e racional. Nesta obra de Teolinda, ao ler a referência ao mito de Er, o leitor depara-se com a discussão platônica sobre a escolha que cada ser humano faz para seu modo de vida. Júlia, desde o início da obra, já realiza suas escolhas, a princípio defendendo Mozart em vez de Beethoven. Obviamente, o leitor tem conhecimento de que, no início do enredo, tal defesa é muito mais intuitiva do que racional. Isso é percebido na primeira frase do romance, em que o leitor é apresentado à protagonista como uma criança que faz preces por Mozart. Entretanto, no decorrer da narrativa, Júlia faz reflexões e escolhas mais racionais e conscientes para seu modo de vida, em busca da "verdade" por ela procurada. E sua primeira verdade é encontrada, ou melhor, projetada em Mozart. Mozart e Beethoven iniciam a narrativa da obra de Gersão representando valores ético-estéticos divergentes entre si, cujos defensores são, respectivamente, Júlia e tio Octávio.

Desse modo, o mito de Er, em especial a releitura sartriana, apresenta-se, aqui, como "possibilidades de existência e não como imposição de existências; isto é, o homem escolhe seu modelo de vida com total conhecimento de causa, pois tem não só todos os elementos para a deliberação, mas também a razão para deliberar." (DROZ, 1997). Vale a ressalva de que Júlia adquire essa consciência de deliberação para sua vida conforme cresce e amadurece em sua história, e a música, como meio pelo qual ela está se autodescobrindo, tem papel importantíssimo nesse processo de amadurecimento e autoconsciência.

Nesse sentido, percebe-se que há dois fatores importantes nessa citação. A primeira refere-se aos valores ético-estéticos (Mozart e Beethoven) díspares, entre os quais se elege o que pode ser considerado como boa música, mostrando que os pontos de vista são diferentes, assim como o Bem e o Mal, dependendo do julgamento dos homens para serem formulados. A segunda aponta para a ideia de que a preferência artística está carregada de valores éticos, auxiliando na formação ética do sujeito a partir de suas escolhas, como faz Júlia ao defender Mozart, ao invés de se submeter aos valores estabelecidos por tio Octávio.

Tanto o mito de Sartre quanto o de Platão passam pela problemática do que "seria a arte e qual seria sua função, para, então, concluir novamente com a questão ética" (SOUZA, 2006, p.114). Se, em Platão, a moral está baseada, de forma racional, 
no Ser idealizado no mundo das ideias e, portanto, a arte, como forma mimética, deve ser desprezada, pois só leva o Ser a um movimento ligado às paixões em vez da razão, em Sartre, a moral está ligada ao movimento de criação, como a arte, e, principalmente, acontece através das vivências do Ser, ou seja, de suas experiências vitais.

Desse modo, segundo Souza (2006):

[...] podemos fazer algumas deduções a partir do que Er nos revela: se o Bem e o Mal não existem no mundo, se a moral é um julgamento feito pelos homens, então podemos dizer que só se pode pensar em uma moral do mesmo modo como se pensa a arte, ou seja, como criação. A moral deve ser tão criada e inventada como uma obra de arte: sem existência real ou ideal a que recorrer o homem não tem em que fundamentar sua ética. Por isso, a única maneira de se estabelecer valores é criando-os, imaginando-os. A arte não seria, então, superior à moral, mas se identificaria com essa pelo processo criativo e imaginário [...]. (p.116)

Como a moral é vista como arte, ou seja, um processo de criação e de imaginação, as vivências do Ser são fundamentais para se estabelecer valores e criar a arte. Assim como ocorre com Júlia, que, a partir de suas vivências, busca formular os valores éticos, constituindo-se como sujeito por meio de suas vivências com as pessoas e com a arte musical. Nesse aspecto, o Er sartriano auxilia na leitura de Os Teclados, no sentido de que revela o ser em busca do seu autoconhecimento a partir de suas vivências, sendo a mesma experiência vivenciada por Júlia, principalmente em suas reflexões sobre a arte musical.

A conclusão do Mito de Er também aponta para a conclusão de Júlia após seu amadurecimento, uma vez que se percebem a arte e a moral como criações a partir das vivências do existir. Desse modo, como estas vivências se modificam o tempo todo, tanto a arte como a moral estariam sempre em construção e, portanto, nunca concluídas. O leitor da obra Os Teclados percebe, no fim da narrativa, que a obra não se conclui com uma "moral da história", mas, ao contrário, apresenta uma reflexão sobre a construção de valores éticos e estéticos ao longo de nossas experiências, estabelecendo mudanças no ser. Por isso, talvez o livro finalize focalizando uma adolescente sentada 
ao piano e tocando para uma plateia vazia, esperando o devir, num processo de continuidade na sua autoconstituição e apontando para uma formação ética até ali estabelecida, porém não concluída, logo em constante transformação. No trecho a seguir, observa-se a finalização da obra, assim como aconteceria com a formação do ser e da obra de arte:

O trabalho sobre o teclado era porventura a transcendência que restara? Tudo se reduzia então a um mundo deserto, onde cabia no entanto uma exigência rigor que era uma forma de virtude, a sua forma de virtude - como tinha dito a do outro teclado?

Podia aceitar que assim fosse, pensou olhando em volta as cadeiras desertas. Aceitar o nada, o mundo vazio.

E apesar disso, pensou levantando-se e sentando-se no banco - apesar disso sentar-se e tocar. (GERSÃO, 1999, p. 95).

Aceitar que a grande verdade não pode ser encontrada em uma única filosofia, nem em uma relação social, nem em um objeto artístico, mas perceber que esta verdade se modifica ao longo da vida através das experiências, é compreender que a transcendência buscada por ela, Júlia, estaria ligada à arte (por isso ela continua a tocar, mesmo para uma plateia vazia). Todavia seria inconclusa e, portanto, uma busca contínua.

\subsection{0 mito das sereias}

Outro diálogo que também está presente nesta obra de Gersão se faz com o mito das sereias. Mesmo que as sereias já sejam citadas no Mito de $E r$, a ênfase do enredo d'Os Teclados parece apontar para o tradicional Mito das Sereias já apresentado em diversas obras literárias e não só para aquele presente no mito platônico.

Primeiramente, verifica-se que, no romance, a citação das sereias aparece após a referência ao Mito de Er: “(...) em cada um dos oito círculos dos planetas havia uma 
sereia, girando com as esferas e cantando a harmonia com as três Moiras." (GERSÃO, 1999, p.76).

No Mito de Er, cada planeta emitiria um som e todos eles juntos formariam a música do universo, num canto entoado por sereias, cada uma em um planeta, estabelecendo uma harmonia com as Moiras (Parcas), espécie de feiticeiras que comandam o fio da vida das pessoas a partir de suas escolhas no reino dos mortos.

Durante a narrativa, paralelamente à descrição do Mito das Sereias, o narrador relata os pensamentos de Júlia no seu encontro com o professor Rogério no café. A metáfora das sereias que ali aparece como um refrão musical (que será explicado no capítulo sobre Harmonia) funciona como uma explicação dos pensamentos, sentimentos e ações de Júlia naquele instante e em sua busca pelo sentido da vida. Para destacar essa análise vale repetir o trecho que já foi citado anteriormente nesta dissertação:

[...] em cada um dos oito círculos dos planetas havia uma sereia em harmonia com as três Moiras.

(Ela caindo dos mundos, de esfera em esfera, presa por um pé. Descendo vertiginosamente através dos planetas. Em cada um uma sereia olhando.)

(Em cada planeta uma sereia olhando com o rosto dela própria.)

(As sereias cantavam em harmonia com o destino. Que era sempre o mais forte.)

(Elas penteavam os longos cabelos, sentadas nos rochedos. As sereias. E cantavam.) (GERSÃO, 1999, p.77-79).

Neste momento, destacou-se o seguinte trecho: “(Ela caindo dos mundos, de esfera em esfera, presa por um pé, descendo vertiginosamente através dos planetas. Em cada um uma sereia olhando.)" (GERSÃO, 1999, p. 78), onde Júlia projeta sua imagem em uma sereia que desce de planeta em planeta, como uma espécie de trapezista imaginária, sendo observada pelas demais sereias.

Com sua beleza e seu canto, as sereias representam a sedução e o perigo. Ao cantar, elas hipnotizam aqueles que as ouvem, geralmente, levando-os à morte. Álvaro Cardoso Gomes, em seu livro O poético: magia e iluminação, descreve as sereias como seres mitológicos e sedutores: 
A sereia, espécie mítica de ser, por fundir o humano ao animal, representa as "forças inferiores na mulher ou o símbolo da imaginação corrupta seduzida pelos primitivos estratos da vida". Ora, por isso que ela se comunica através do canto, tipo de expressão em que o estrato sensível predomina sobre o intelectual. A música é a mais subjetiva das artes e, assim se presta a conduzir a emoção de modo mais direto, agindo, em consequência, sobre os sentimentos do ouvinte. A ação da sereia sobre o pescador visa aos estratos do inconsciente, através da atração do abismo, o mar, um dos símbolos mais tradicionais do mundo baixo dos instintos. (p.133).

As sereias, através do seu canto, seduzem as pessoas e as levam à morte no abismo do oceano. Em Os Teclados, Júlia tenta seduzir o professor ao longo da conversa cujo tema é a formação do universo. As explicações realizadas por Rogério Souto passam pela música, uma vez que Pitágoras, Platão e Kepler são citados pelo professor e todos esses filósofos tentaram explicar a formação do universo através de elementos musicais.

Portanto, em uma mesma sequência de trechos, Gersão retoma o Mito de Er de Platão, bem como o Mito das Sereias, diversas vezes apontado na Literatura.

A sequência do Mito de Er é intercalada pelas reflexões de Júlia sobre o poder da música. Segundo Rogério Souto, a “[...] música curava as almas porque as fazia regressar à origem, ao primeiro princípio [...]" (GERSÃO, 1999, p. 77) e sobre seu poder de sedução, “[...] Queria saber se um homem poderia amá-la. Apesar do teclado.” (GERSÃO, 1999, p.79). Pela metáfora das sereias, percebe-se uma trajetória de reflexão enigmática realizada por Júlia ao tentar desvendar-se a si mesma, refletindo sobre o mito narrado pelo professor e suas ações no café.

Na tradição literária, o Mito das Sereias aparece na Odisseia ${ }^{5}$ de Homero e em poemas como Barca Bela, de Almeida Garret. Em ambas as referências literárias, e o

\footnotetext{
${ }^{5}$ Segue o trecho, retirado da Odisseia de Homero, sobre o mito das sereias: “Toda esta primeira provação está concluída. Escuta agora o que vou dizer-te; aliás um deus de novo te recordará isso mesmo. Chegarás, primeiro, à região das Sereias, cuja voz encanta todos os homens que delas se aproximam. Se alguém, sem dar por isso, delas se avizinha e as escuta, nunca mais sua mulher nem seus filhos pequeninos se reunirão em torno dele, pois que ficará cativo do canto harmonioso das Sereias. Residem elas num prado, em redor do qual se amontoam as ossadas de corpos em putrefação, cujas peles se vão ressequindo. Prossegue adiante, sem parar; com cera doce como mel amolecida tapa as orelhas de teus companheiros, para que nenhum deles possa ouvi-las. Tu, se quiseres, ouve-as; mas que em tua nau ligeira te atem pés e mãos, estando tu direito, ao mastro por meio de cordas para que te seja dado experimentar o prazer de ouvir a voz das Sereias. Se acaso pedires e instares com teus homens que te soltem, que eles te prendam com maior número de ligaduras." (HOMERO, Odisseia .Tradução de Antônio Pinto de Carvalho, São Paulo: Abril Cultural, 1981. Rapsódia XII, p.113).
} 
recorte retoma o poder do canto das sereias e seus atos de sedução. Odisseu (Ulisses), com o desejo de ouvir o canto das sereias, pede aos seus marinheiros que o amarrem no mastro do navio e coloquem cera em seus ouvidos, de modo que ele possa ver as sereias sem se deixar hipnotizar por seu canto. Por precaução, exigiu que cada marinheiro seu tapasse os ouvidos, assim ele poderia apreciar as sereias, mas o navio estaria seguro, pois seus marinheiros não seriam seduzidos pelo canto delas. Os navios que não tomavam essa precaução acabavam sendo levados pelos próprios marinheiros para próximo das sereias e, por fim, eram destruídos em naufrágios.

No decorrer da narrativa, Júlia questiona-se sobre o público e a relação dele com o musicista. Os episódios que a colocam frente ao tio Octávio, à Ireninha e à trapezista vão, aos poucos, libertando-a da crença de que a plateia exerça um papel preponderante na vivência artística.

No tocante ao episódio acima, Júlia ora assume o papel das sereias, na intenção de seduzir o professor de matemática, ora assume o papel de Odisseu, na sua reflexão crítica que germina, sobre a relação da musicista com o público, e em seu papel de ouvinte. Amarrado ao mastro, Odisseu, privado de força, de poder e de vontade, significará a passividade do espectador, a imobilidade de quem assiste ao concerto, ao filme, ao drama, ao espetáculo, atado à cadeira, passivo. Ele pode evocar o grito apaixonado daquele que deseja a libertação, entretanto é abafado pelo aplauso. Como na obra há um possível diálogo entre criadora (Gersão - projetada em Helena Estevão) e criatura (Júlia), a "vingança" da escritora estaria em levar o leitor a vivenciar os mesmos medos e riscos pelos quais passa no ato da escrita. Através da personagem Júlia e dos parênteses realizados pela autora, o leitor é lançado ao universo de Odisseu e ao mito das sereias, ao movimento de sedução que cada uma delas elabora e seu canto da morte e, a partir destas metáforas, pensa sobre sua própria passividade diante da obra de arte, como plateia inerte do canto.

Em relação à música, e com base no mito explorado, ela teria o poder da hipnose, assim como o canto das sereias, ou ainda o poder da sedução da fala do professor de matemática naquele instante.

No trecho que se segue, cada sereia possui o rosto de Júlia. Tem-se, então, um processo de projeção da protagonista sobre o mito, “(Em cada planeta uma sereia olhando. Com o rosto dela própria)" (GERSÃO, 1999, p .79). Júlia também seduzia enquanto se deixava seduzir. As sereias com seu rosto também reportam à ideia de um 
enigma a ser desvendado. Ela também era um mistério para si, por isso estava se descobrindo e se constituindo como sujeito por meio das experiências vivenciadas.

No episódio em que Júlia está no café, ela realiza o mesmo movimento das sereias na citação:

Inclinou a cabeça sobre o copo de limonada e o cabelo que deixava crescer caiu-lhe sobre a cara.

(Elas penteavam os longos cabelos, sentadas nos rochedos. As sereias. E cantava). (GERSÃO, 1999, p. 79).

A sedução, na cena acima, ocorre, portanto, de ambos os lados: a menina tenta chamar a atenção sobre si, enquanto o professor (talvez sem o saber) a seduz, explicando-lhe um mito de sedução. Nesse momento a busca de Júlia atende a um novo desejo: o "sentido" ou verdade que ela buscava incorporar também os anseios de uma sensualidade recém-despertada.

Júlia é uma personagem em aprendizagem e, por meio das mais variadas metáforas, como a trapezista, o Mito das Sereias, o Mito de Er ou o teclado de papel, leva o leitor a realizar uma reflexão sobre a arte na contemporaneidade e sobre a relação do individuo com essa arte - relação intermediada pelo desejo.

Mas, em um mundo em que predominam a troca de valores, a velocidade das informações e a massificação da arte, qual seria o papel do leitor, do escritor, do artista? São estas as reflexões do próximo capítulo. 


\section{CAPÍTULO II}

\section{JÚLIA E SEUS PRIMEIROS}

INSIGHTS SOBRE A RELAÇÃO ARTE-PÚBLICO 


\section{CAPÍTULO II}

\section{JÚLIA EM SEUS PRIMEIROS}

\section{INSIGHTS SOBRE A RELAÇÃO ARTE-PÚBLICO}

Este capítulo tem por objetivo abordar a reflexão das personagens Júlia e Helena Estevão sobre a arte no contexto social e sobre as implicações da transformação da obra em mercadoria. A partir das reflexões estabelecidas por essas personagens, o leitor de Os Teclados também é levado a pensar criticamente sobre as relações que a sociedade contemporânea estabelece com a arte.

A personagem Helena Estevão, escritora que dá uma entrevista para um jornal que será lido posteriormente por Júlia aparece para o leitor como uma espécie de ideóloga ${ }^{6}$ cuja função, no texto, é de inserir um comentário crítico a respeito do rebaixamento do valor intrínseco da obra artística na medida em que é transformada em mercadoria. Abaixo, segue um trecho da entrevista de Helena Estevão:

Sim, ela diria que havia uma espécie de zombificação do mundo, que se tinha transformado em mercado - vivia-se no instante, procurando apenas os valores de troca. Mas não pretendia julgar o mundo, e aceitava que talvez o zombie fosse ela.

Era verdade que tempo parecia ter sido terrivelmente encurtado (Kant, Platão, Wittgeintein em dezasseis minutos, prometiam nas bancas livros magros como folhetos). Mas os livros aconteciam no tempo. Como a música. Os romances, sobretudo. Eram, como a música, uma forma de medir e organizar o tempo. (GERSÃO, 1999, p.54).

Helena fala em sua entrevista sobre os valores de troca presentes na sociedade contemporânea. O tempo para se ler um livro teria diminuído, uma vez que a obra não estaria na íntegra, mas sim resumida em "livros magros como folhetos". Por meio destas

\footnotetext{
${ }^{6}$ O termo "ideóloga" é extraído da teoria bakhtiniana sobre o herói dostoievskiano, e significa uma voz representativa de uma ideia. Neste caso, a personagem Helena, a nosso ver, pode ser compreendida como aquela que levará o leitor a pensar criticamente sobre o rebaixamento do Arte na sociedade contemporânea.
} 
palavras de Helena, o leitor é levado a iniciar uma reflexão crítica sobre a relação entre o indivíduo desta sociedade contemporânea e a arte.

Através das reflexões de Helena, abordadas a seguir, Júlia reconhece, nas angústias da escritora ("a do outro teclado", como ela a chamou), uma semelhança com as suas próprias angústias em relação à música. A partir do momento da narrativa em que Júlia encontra o encarte de jornal com a entrevista de Helena, percebe-se que a obra sofre uma espécie de divisão.

Até esse momento, numa primeira parte, o narrador apresenta o universo de Júlia, sua casa, seus tios, seus professores e, principalmente, a relação dela com a música. Júlia está, então, em busca de um sentido para a vida. Sentido este, que, a princípio, ela crê poder encontrar através da música. No decorrer da narrativa, Júlia transfere a construção desse sentido para outras linguagens ou sistemas que a escola lhe apresenta, como a Física ou a Matemática, por exemplo.

Numa segunda parte, após encontrar o encarte de jornal com a entrevista da escritora, ela e o leitor são lançados a uma reflexão sobre a arte literária e, em especial, sobre sua relação com a indústria cultural. É este último o tema que aflora, a partir de então, como conflito central implícito na aprendizagem de Júlia, que é também, uma aprendizagem do leitor: a arte como mercadoria em contraposição à arte como via de transcendência.

A compreensão dos conceitos abordados por Gersão ao longo da narrativa demanda que sejam explorados os conceitos de arte e de troca. A arte, ou melhor, o objeto de arte, segundo a concepção apresentada na narrativa, pode ser entendido de duas formas diversas: uma, como obra de valor genuíno, e outra como objeto cujo valor é dado pelo sistema regulatório do mercado. O trecho abaixo retrata a preocupação de Helena com relação à arte literária especificamente. Para esta personagem, a arte não pode prescindir de uma vivência compartilhada de valores entre escritor e leitor. No entanto, segundo ela observa, a tarefa do escritor parece-lhe cada vez mais solitária, conforme se lê no trecho a seguir:

Talvez não, tudo no mundo era fragmentário, as pessoas não formavam comunidades e só havia valores de troca. Talvez fosse indiferente aos outros se ela ia ou não passar a vida tentando atravessar o teclado. Talvez estivesse no fundo sozinha, e a loucura fosse apenas dela. (GERSÃO, 1999, p. 56). 
Para Helena, a sociedade perdeu os elos com a concepção genuína da arte, ou seja, a arte como elemento transformador do ser, cuja valoração depende, essencialmente, de sentidos produzidos pelo diálogo social.

No trecho acima, também se pode observar o resultado de um rebaixamento histórico da arte, ou seja, o fato de o objeto de arte ter se transformado em mercadoria, em objeto de troca. A partir da ascensão da burguesia, a arte passou a ser comercializada para ostentar poder, riqueza, isto é, um status social e aparência de refinamento estético e bom gosto. Anteriormente a esse período, a nobreza tinha por tradição adquirir obras de arte para serem apreciadas em suas salas, durante encontros com amigos e convidados. Obviamente, esta arte também possuía valor econômico e social, todavia, a nobreza privilegiava a apreciação do objeto de arte com seu valor genuíno, como experiência estética. Já a burguesia, principalmente a partir do Século das Luzes, desejando atingir o mesmo status social da nobreza, adquiria objetos de arte para ostentar poder. $\mathrm{Na}$ maioria das vezes, entretanto, tais objetos eram avaliados e apreciados tão somente pela sua função decorativa e índice do poder econômico do proprietário, sem consideração alguma pelo seu valor estético-cultural. Logo, a arte passou a ter dois valores: o valor genuíno, estético e o valor de mercadoria, com cada vez mais espaço no âmbito social. ${ }^{7}$

Esse objeto de arte só pode instaurar uma relação de troca (num sentido muito particular e impreciso de troca) cultural com seu apreciador, na medida em que este apreende, da sua concepção artística, os valores culturais ali expostos. A contemplação de uma obra de arte, no sentido do valor genuíno desta, possibilita que haja um intercâmbio cultural. O observador, para realizar a interpretação, traz para este momento os elementos culturais nos quais está inserido, para, a partir deles, elaborar sua valoração do objeto artístico. Simultaneamente, o observador apreende, do objeto de arte que contempla, elementos culturais, como tempo histórico, características estéticas de um período específico ou autor, valores éticos, mitos, dentre outras informações. Por meio desta interação, dá-se o que imprecisamente se pode chamar de "troca cultural" e o observador, realizando-a, cresce como indivíduo, ao aprender valores transmitidos pelo objeto de arte e, a este mesmo objeto, imprimindo valores outros: esta é a arte vivida socialmente, no seu sentido transcendental.

\footnotetext{
${ }^{7}$ BENJAMIN, Walter. Magia e técnica, arte e política. São Paulo: Brasiliense, 1985.
} 
Por isso, a experiência artística carrega valores coletivos, que atingem um grupo que a vivencia, uma vez que transmite valores da época em que foi elaborada e em que é recebida, como também aciona valores individuais, pois o universo social e vital a que cada indivíduo recorre, no ato interpretativo do objeto artístico, depende de sua experiência de vida, classe social, cultura, gênero, idade, enfim, é uma experiência individual. Por conseguinte, compreende-se por que uma obra de arte pode seduzir ou encantar uma pessoa, enquanto outra não a toma por algo importante, pois a experiência artística, no sentido genuíno, é uma vivência individual.

Em Os Teclados, Júlia vai, gradativamente, compreendendo a arte em seu sentido genuíno. Ela crê, inclusive, no poder da música para curar as almas das pessoas. Como ela teria gostado que ocorresse com o tio Eurico, quando, batendo as palmas, pediu-lhe que batesse ${ }^{8}$ com ela o compasso. A reação dele, no entanto, é frustrante, como se depreende do fragmento abaixo:

Ele não pareceu ouvir, continuou parado encostado à parede, com a cabeça caída sobre o peito. Ela bateu outra vez, marcando um ritmo, e como ele continuou sem dar acordo, levou-o pela mão para a sala, sentou-se no banco do piano e toucou as primeiras frases do tango Camiñito. Uma vez e outra, até que ele pareceu entender, correu a buscar a colher de pau e começou alegremente a bater nos móveis.

Ela repetia a melodia, marcando o ritmo cada vez com mais força. Sentado no chão, ele continuava a bater. (GERSÃO, 1999, p. 41-42) ${ }^{9}$.

Na sua concepção, a música, organizada temporalmente, conseguiria trazer tio Eurico à realidade do mundo ${ }^{10}$. Segue abaixo outro trecho sobre a ideia de arte como forma de "cura das almas":

\footnotetext{
${ }^{8}$ A repetição do verbo "bater" na transcrição acima visa enfatizar o som sincopado por meio do qual Júlia pretende estabelecer a conexão entre o tio Eurico e a música. No texto original, está assim: "Bata comigo o compasso, disse de súbito, batendo as palmas."

${ }^{9}$ No romance, A montanha mágica de Thomas Mann, há a seguinte definição sobre o tempo e a narrativa: "[...] tivesse a ideia de manter durante uma hora um e mesmo tom ou acorde e afirmasse ser isso música. Pois a narrativa se parece com a música no sentido de que ambas dão um conteúdo ao tempo[...]” (p. 601) ${ }^{10}$ Como a música, organizada temporalmente, poderia resgatar Eurico, é parte do tema desenvolvido no capítulo VI, que versará sobre o tempo.
} 
A música curava as almas porque as fazia regressar à origem, ao primeiro princípio, dizia Rogério Souto, voltando às citações. [...] A música curava as almas. Ela [Júlia] também acreditava nisso. Tentara curar o tio Eurico, prendê-lo de novo ao tempo. Mas ele permanecera desligado. Nunca iria voltar. Por muito que ela se esforçasse, nunca iria trazê-lo de volta, não tinha esse poder. (GERSÃO, 1999, p.78).

O contato epifânico entre Júlia, a arte e o mundo, que se dá a partir da leitura da entrevista com a escritora Helena Estevão, desencadeia suas indagações principais a respeito da qualidade das relações sociais, da configuração mercadológica da arte contemporânea e da ausência de um sentido pronto do existir. Desde o momento em que sai do consultório do dentista, os efeitos da leitura na consciência de Júlia se tornam mais concretos e têm início as primeiras sequências de perguntas interiores, que surgem em jorro, no seguinte monólogo interior:

Sentiu vontade de entrar em sua casa e interrogá-la, como se pudesse encostá-la à parede e pedir-lhe contas de a ter inquietado: $\mathrm{O}$ que significava zombificação? Por que razão o tempo encurtara e tudo se convertera em mercado? Que queria ela dizer, finalmente? Havia ou não um sentido no mundo? (GERSÃO, 1999, p. 58).

Na esteira da produção joyceana e clariceana, a protagonista de Os Teclados tem a sua primeira apreensão consciente (não ainda em nível de apreensão conceitual) do mundo, o que, como se viu acima, desestabiliza-a de tal modo que a angústia produzida transforma-se, na narrativa, em dor física:

De repente irritava-se contra aquela mulher que falava com serenidade sobre o vazio, confortavelmente sentada na cadeira, enquanto ela, 
Júlia, caminhava debaixo de chuva, com os sapatos encharcados e aquela dor na gengiva.

Uma visão desencantada poderia ser suportável, desde que se tivesse uma boa dose de felicidade individual, pensou. (GERSÃO, 1999, p. $58)$.

Segundo explica Benedito Nunes acerca da concepção heideggeriana de angústia, desenvolvida em Ser e Tempo,

O mal estar da angústia provém da insegurança de nossa condição, que é, como possibilidade originária, puro estar-aí (Dasein). Abandonado, entregue a si mesmo, livre, o homem que se angustia vê diluir-se a firmeza do mundo. O que era familiar tornar-se-lhe estranho, inóspito. Sua personagem social recua. O círculo protetor da linguagem esvazia-se, deixando lugar para o silêncio. (p.95)

A insuportável dor que Júlia sente na gengiva sugere-se como correlata à dor metafísica da angústia e da percepção da falta de sentido da existência: "De repente irritava-se contra aquela mulher que falava com serenidade sobre o vazio, [...]"(GERSÃO, 1999, p.58). Essa dor pontua também, na narrativa, o momento epifânico desencadeador da formação de uma autoconsciência chegando a tocar a parede de vidro que separa Júlia de sua criadora. O vazio de que Júlia se ressente, pelo entendimento incômodo do discurso da escritora, ameaça a credulidade da menina que se vê "sem lugar" no mundo circundante.

A partir dessa epifania, Júlia é levada pelas palavras da escritora Helena a refletir criticamente sobre o tempo na vida moderna. Esta impõe aos homens um ritmo de vida muito rápido; logo, se o tempo é exíguo para a realização das tarefas do cotidiano, pode-se imaginar como fica inviável apreciar, genuinamente, um objeto artístico, uma vez que se necessita de um tempo consideravelmente longo para que a contemplação aconteça. Nessa conjuntura contemporânea, a única troca possível só se pode efetuar no ato instantâneo da compra e, quando muito, na leitura apressada de obras resumidas e/ou de fácil consumo. 
É sobre isso que Júlia pensa no seu caminho para casa tentando refletir sobre o desenho do mundo em que vivia:

Meia hora mais tarde, de novo na rua, tudo lhe veio novamente à ideia. As pessoas não formavam comunidades, tudo era fragmentário e no fundo indiferente porque todos os valores eram de troca. $\mathrm{O}$ mundo era um monte de estilhaços, era isso o que a mulher tinha dito? (GERSÃO, 1999, p.57).

De fato, com o advento do objeto de arte como troca de mercado, inicia-se na sociedade o que Adorno chamará de Indústria Cultural ${ }^{11}$, que acaba destruindo, por meio da relação de troca comercial estabelecida entre ser humano e objeto artístico, a aura da arte.

O conteúdo de uma obra de arte, até o século XIX ${ }^{12}$, era dado pela contemplação, ou seja, pela relação que se estabelecia entre o ser humano com o objeto de arte, e por meio desse intercâmbio entre arte e homem, ele poderia apreender mitos, conceitos éticos, características de um período histórico, estético, entre outros valores, como já foi dito. A isto Walter Benjamin em sua obra, Magia e técnica, arte política, chama aura:

[...] É uma figura singular, composta de elementos espaciais e temporais: a aparição única de uma coisa distante, por mais perto que ela esteja. Observar em repouso, numa tarde de verão, uma cadeia de montanhas no horizonte [...] significa respirar a aura dessas montanhas [...]. (p. 170)

\footnotetext{
${ }^{1111}$ ADORNO, Theodor. In: A Indústria cultural - o Iluminismo como mistificação das massas. Indústria Cultural e sociedade. São Paulo: Paz e Terra, 2006.

${ }^{12}$ BENJAMIN, Walter. Obras Escolhidas - Magia e técnica, arte e política. $4^{\text {a }}$.ed São Paulo: Brasiliense. p. 166-188.
} 
Ou seja, a aura é aquilo que é transmitido pelo objeto de arte dentro de um espaço e de um tempo. Por isso, faz-se necessário um tempo para assimilar a aura da arte e a observação de seu espaço no mundo. Na definição imagética de Benjamin, destaca-se a importância do distanciamento necessário dessa captação: “a aparição única de uma coisa distante, por mais perto que ela esteja." Logo, não há a possibilidade de uma obra de arte ser devidamente apreciada a curto prazo, sem o tempo necessário de repouso, sem a profundidade do olhar.

No entanto, cada obra, por mais que emulasse um universo artístico anterior ${ }^{13}$, teria uma aura própria e única, que seria observada como experiência também única de encontro entre o indivíduo e o objeto artístico. Por conseguinte, a cada olhar sobre uma pintura, a cada audição de uma peça musical, a cada apreciação de um poema, o espectador/ouvinte/leitor passaria por uma nova experiência. Essa experiência poderia ser modificada em função do tempo de apreciação dedicado à obra de arte, ou da experiência de vida adquirida, ou ainda, em função do contexto histórico do observador.

Logo, a aura da obra de arte, a cada momento, é única e, por mais que represente um período histórico ou estético, sua observação é uma experiência irrepetível entre o ser e o objeto. Mas compreender essa relação única para o artista é uma lição difícil para os treze anos da menina Júlia. Portanto, as palavras de Helena requeriam-lhe tempo e esforço de compreensão.

Entretanto, voltando ao texto de Benjamin, na obra já citada acima, a aura da obra de arte sofre inevitável abalo diante da reprodutibilidade técnica,

[...] é fácil identificar os fatores sociais específicos que condicionam o declínio atual da aura. Ele deriva duas circunstâncias, estreitamente ligadas à crescente difusão e intensidade dos movimentos de massas. Fazer as coisas "ficarem mais próximas" é uma preocupação tão apaixonada das massas modernas como sua tendência a superar o caráter único de todos os fatos através da sua reprodutibilidade. ( $\mathrm{p}$ 170.)

\footnotetext{
${ }^{13}$ No conceito aristotélico de que todos os artistas realizam a imitação artística.
} 
Evidentemente, Walter Benjamin não está questionando a reprodução da obra de arte, pois ele mesmo reconhece que a arte sempre foi reprodutível, é só observar os discípulos imitando seus mestres. Mas a questão se coloca na nova modalidade de reproduzir, isto é, na reprodução técnica.

A reprodução técnica permite a existência do objeto artístico em série, e no caso de alguns objetos artísticos, como discos, cinema e fotografia, torna-se impossível a distinção entre original e cópia. Prossegue Benjamin:

\begin{abstract}
Em sua essência a obra de arte sempre foi reprodutível. O que os homens faziam sempre podia ser imitado por outros homens. Essa imitação era praticada por discípulo sem seus exercícios, pelos mestres, para a difusão das obras, e finalmente por terceiros, meramente interessados no lucro. Em contraste, a reprodução técnica da obra de arte representa um processo novo, que se vem desenvolvendo na História, intermitentemente, através de saltos separados por longos intervalos, mas com intensidade crescente. (p.166)
\end{abstract}

Benjamin, ao escrever sobre a mudança das artes nos anos 30, tinha em mente uma grave situação histórica e um ideal, ou seja, o nazismo e a revolução socialista. Ele, esperançoso numa revolução socialista que prometia a emancipação do gênero humano, expressava o desejo de considerar favorável a perda da aura da arte como processo de democratização da Cultura, através do direito às obras artísticas para toda a sociedade, em especial, para os trabalhadores.

Entretanto, o desejo expressado por Benjamin cai por terra com a massificação propagandística da arte, que não havia terminado com o nazi-fascismo. O stalinismo desfigurou a esperança socialista e, nos países capitalistas, a ideia de massificação da arte foi incorporada. Surgia, então, a cultura de massas, voltada para a reprodutibilidade técnica da obra de arte, cuja função passa a ser de objeto de mercado. Nesse novo contexto, a aura passa por um processo de destruição. A reprodutibilidade prezará pelo lucro em detrimento de uma relação em que ser humano e objeto artístico sejam os coprodutores de sentidos. 
Em Os Teclados, Helena expressava o desejo de que os leitores se entregassem à leitura do mesmo modo que ela se entregava ao ato criador da obra literária. Frustrada a princípio, percebe que são raros aqueles que realizam a ação da entrega ao ato da leitura, a ponto de permitir que o tempo de fruição e intelecção da obra literária seja respeitado. As pessoas, na contemporaneidade, desejam livros "magros como folhetos", de rápido entendimento e poucas elucubrações metafóricas ou referências filosóficas e históricas - é a arte imediatista, ou seja, a arte da reprodutibilidade técnica.

Sobre o processo de destruição da aura ${ }^{14}$ da obra de arte, Benjamin afirma ainda que: "No interior de grandes períodos históricos, a forma de percepção das coletividades humanas se transforma ao mesmo tempo em que seu modo de existência".. (p. 169) ${ }^{15}$. Percebe-se, em suas palavras, que a destruição da aura da obra de arte está intimamente ligada à crescente difusão dos movimentos de massas. O movimento de massas deseja que as coisas fiquem mais próximas, ao alcance de todos, e sua tendência é a superação do caráter único de todos os fatos através da reprodutibilidade. Noutras palavras, reproduzir a obra de arte como objeto de mercado teoricamente faria com que ela se tornasse mais acessível a uma apreciação mais ampla e democrática.

Entretanto, e como já foi dito, o modo de percepção da obra de arte modifica-se a partir do advento da burguesia. Até o Romantismo, a aura da obra era mais valorizada, uma vez que se acreditava no poder de transcendência do indivíduo por meio dela. $\mathrm{O}$ observador da arte nessa época apreendia valores e transformava seu ser por meio do objeto contemplado em seu valor de troca cultural. Como essa burguesia não possuía os instrumentos de valoração estética da nobreza, ela opera uma inversão nos valores aplicados ao objeto de arte. Essa concepção do objeto de arte como mercadoria chega aos séculos XX e XXI e, inflacionados pela velocidade de informações da modernidade, passará, ainda, pela erosão do imediatismo. Com o advento do cinema, num estágio avançado das técnicas de reprodutibilidade técnica, a ideia da aura da arte e da experiência artística única do indivíduo acabam perdendo-se ou limitando-se à raridade, pois o cinema apresenta uma arte da coletividade, propícia à massificação, não raro utilizada como reafirmação do pensamento dominante e do senso comum. ${ }^{16}$

Segundo Adorno (2006),

\footnotetext{
${ }^{14}$ Aura - “[...] É uma figura singular, composta de elementos espaciais e temporais: a aparição única de uma coisa distante, por mais perto que ela esteja. Observar em repouso, numa tarde de verão, uma cadeia de montanhas no horizonte (...) significa respirar a aura dessas montanhas [...]" (Ibid. , p. 170).

${ }^{15}$ Ibid., p. 169.

16 É forçoso, aqui, fazer uma ressalva à essa generalização: o cinema tem produzido, na contramão dessa tendência, obras de grande valor artístico, desde o seu advento.
} 
[...] o filme não deixa à fantasia e ao pensamento dos espectadores qual dimensão na qual possam - sempre no âmbito da obra cinematográfica, mas desvinculados de seus dados puros - se mover e se ampliar por conta própria sem que percam o fio. [...] Os próprios produtos [...] paralisam aquelas capacidades pela sua própria constituição objetiva. Eles são feitos de modo que a sua apreensão adequada exige, por um lado, rapidez de percepção, capacidade de observação e competência específica, e por outro é feita de modo a vetar, de fato, a atividade mental do espectador, se ele não quiser perder os fatos que rapidamente se desenrolam à sua frente. (p. 16)

Com o tempo para assimilar a aura da arte diminuído devido à velocidade das informações transmitidas pelos filmes, o homem não teria mais o tempo necessário para refletir sobre todas as cenas ou informações transmitidas pela arte cinematográfica. $\mathrm{O}$ cinema, acima de tudo por ser um produto artístico que atinge ao grande público, lança comportamentos sociais coletivos, como a moda, uma nova forma de linguagem ou um produto a ser consumido, reproduzindo-os em massa e sem a reflexão nesse processo de aquisição.

Com a revolução no mercado de trabalho, após as Revoluções Industriais, tem-se a necessidade de uma sociedade formada por "especialistas" em tudo, apartando, por consequência, o indivíduo do convívio social. Nesse momento, o romance, gênero que talvez melhor represente a sociedade e seus múltiplos conflitos, apresenta-se de forma fragmentada, assim como a sociedade moderna, cujos indivíduos não integram mais grupos de discussão sobre arte, gosto e valoração, como havia até a época do Romantismo. O romance, portanto, engaja-se na

[...] tentativa de decifrar o enigma da vida exterior, converte-se no esforço de captar a essência, que por sua vez aparece como algo assustador e duplamente estranho no contexto do estranhamento cotidiano imposto pelas convenções sociais. $\mathrm{O}$ momento anti-realista do romance moderno, sua dimensão metafísica, amadurece em si mesmo pelo seu objeto real, uma sociedade em que os homens estão apartados 
uns dos outros e de si mesmos. Na transcendência estética reflete-se o desencantamento do mundo. (ADORNO, 2008, p.58).

O romance pós-moderno reflete em sua estrutura e/ou personagens a fragmentação da sociedade contemporânea, cada vez mais isolacionista, num processo da progressiva perda da identidade coletiva, uma vez que tais indivíduos vivem "apartados uns dos outros e de si mesmos."

Gersão reflete sobre essa arte contemporânea cujo imediatismo a tornou mercadoria das massas e minimizou a preocupação com a elaboração e vivência artística e, ainda, com a função social que a arte possui sobre o indivíduo. A problemática da indústria cultural, que tomou conta da sociedade contemporânea, invadindo várias áreas como a filosofia, a literatura, as artes plásticas, o cinema e a música, passa a ser objeto de reflexão desse mesmo homem contemporâneo, que pensa seu tempo e a influência dessa cultura na sua visão de mundo. Gersão está entre tais pensadores e projeta em Helena Estevão aquela que irá enunciar esse estado de coisas. Júlia, por sua vez, decodifica o mundo à sua volta, por meio de um incipiente poder de análise sobre ideias filosóficas, literárias e musicais, que lhe chegam ao entendimento em formação utilizando-se, para isso, até da racionalidade matemática como meio para compreender o mundo.

No trecho abaixo, a personagem Helena Estevão reflete a propósito de sua idealização sobre a arte. Tal pensamento parece querer resgatar um tempo em que o ser humano acreditava construir junto à obra de arte, fosse ela música, artes plásticas, ou literatura, a significação de si mesmo e do mundo, em uma relação de troca entre a aura da arte e o homem social:

Ela gostaria de pensar que o leitor era como o escritor, de certa maneira a sua outra face, disse a mulher: Aceitava os mesmos riscos, passava as mesmas noites em claro, tropeçava nos mesmos escolhos, sonhava os mesmos sonhos. Para depois reagir contra eles. Reinventava o livro, como o intérprete tocando a partitura. Por vezes numa direção muito diferente. Era verdade que ela gostava - ou gostaria - de pensar isso, repetiu depois de um silêncio. Mas num 
mundo em que os valores eram de troca, tudo se tornara de certo modo indiferente. O leitor, como o escritor, tornara-se uma personagem rara - (GERSÃO, 1999, p. 55).

Helena Estevão acredita que a arte é transformadora do indivíduo, a partir do instante em que este se torna parte do processo artístico, como o artista, ou como aquele que vivencia a obra de arte como leitor. Para ela, o leitor estabelece uma relação com o livro, ao lê-lo e, por esse motivo, reinventa-o, recria-o a cada leitura. Da mesma forma que procedem os intérpretes ao lerem a partitura. Pode-se falar da retomada do conceito de aura da arte, aqui já abordado, tratado por Walter Benjamin. Ao invés de uma arte como produto de mercado, Helena Estevão retoma a ideia da relação interativa do indivíduo com a obra de arte. Portanto, o ideal de Helena Estevão vai de encontro ao objetivo traçado pela indústria cultural, em que a massificação da arte é vista como um processo de inclusão social do indivíduo.

Todavia, a narrativa oferece exemplos que evidenciam os efeitos negativos da massificação artística da contemporaneidade, ali citados por Helena: "Era verdade que o tempo parecia ter sido terrivelmente encurtado (Kant, Platão, Wittgenstein em dezasseis minutos, prometiam nas bancas livros magros como folhetos) [...]” (GERSÃO, 1999, p.54). A expressão "livros magros como folhetos" já demonstra a força destrutiva da massificação. Assuntos complexos são ensinados em supostos "manuais", através de uma linguagem facilitada e banalizada. Tais obras são justificadas pela pressa desta sociedade contemporânea em obter rapidamente novos conhecimentos sem se preocupar com a qualidade deles, ou com a complexidade que cada assunto apresenta.

Outro conceito, abordado por Gersão, que também perpassa os pensadores da contemporaneidade, é a questão da crise das comunidades. A arte, em sua trajetória, traduz características de períodos históricos, como também de certas comunidades e movimentos artísticos. Tanto a música, a literatura como as artes plásticas têm impressas em suas auras reflexos de acontecimentos, mitos, linguagens e valores éticos sociais do período no qual estavam inseridas e, ainda, de períodos anteriores que foram base para a formação de sua sociedade. Contudo, o homem contemporâneo perde as particularidades impressas em suas expressões artísticas com a chegada das tecnologias da cultura de massa, inclusive em âmbito mundial. Nesse sentido, pode-se dizer que $O s$ Teclados aparecem num momento intervalar, em que não havia mais a interação física (presencial) dos debates sobre política, arte, sociedade etc, nem se praticava, ainda, a 
internet como fórum de discussão. Hoje, a internet é um fórum de debates, ainda que incipientes. Mas, já começa a se esboçar um novo "espaço público".

A autora reflete sobre esta fragmentação por qual passam as comunidades e o isolamento dos indivíduos. No trecho seguinte, Helena Estevão fala sobre a transformação social que deveria acontecer a partir do instante em que as pessoas formassem uma comunidade e trocassem seus conhecimentos, "[...] Porque então não estaríamos sós, a tarefa seria colectiva. Se as pessoas formassem uma comunidade. (...) Talvez não, tudo no mundo era fragmentário, as pessoas não formavam comunidades e só havia valores de troca.” (GERSÃO, 1999, p. 56 - grifo nosso).

No trecho destacado, Helena Estevão pensa como seria bom se as pessoas formassem comunidades em que as trocas culturais fossem constantes. As tarefas de compreender a arte e pensar o mundo seriam elaboradas coletivamente e, por conseguinte, o artista não se sentiria isolado em sua trajetória.

No livro O demônio da teoria - literatura e senso comum, Antoine Compagnon traça um panorama sobre as vertentes da teoria da estética da recepção. Dentre estas vertentes, destaca-se o comentário realizado por ele sobre a teoria apresentada por Stanley Fish,

Fish começara por atacar o texto como objeto autônomo, espacial e formal, quando na realidade ele só existe no interior de uma experiência temporal. Como Iser e Jauss, Fish denunciou, pois, a ilusão da objetividade e da autonomia do texto. [...] destruindo as defesas que cercavam o leitor, ou as rédeas de que se muniam, ele acabou por reivindicar para a leitura o direito da subjetividade e a uma contingência totais. Assim, ele transferiu para o leitor toda a significação, e redefiniu a literatura, não mais como um objeto, fosse ele virtual, mas como "o que acontece quando lemos". [...] Aqui, texto e leitor são prisioneiros da comunidade interpretativa à qual pertencem, a menos que o fato de chamá-los de "prisioneiros" lhes confira ainda mais identidade. (p.159-169)

Fish acreditava que o leitor realiza sua leitura a partir dos valores e sentido do grupo em que está inserido, ou seja, a partir de uma comunidade interpretativa. Para Helena Estevão, o mundo contemporâneo vive a erosão dessas comunidades interpretativas, na medida em que se esquiva do debate sobre as artes, traçando valores éticos e estéticos em relação a ela e a partir delas.

Nas palavras de COMPAGNON (2001), 
Essas comunidades interpretativas, como o repertório de Iser ou o horizonte de expectativa de Jauss, são conjuntos de normas de interpretação, literárias e extraliterárias, que um grupo compartilha: convenções, um código, uma ideologia, como quiserem. (p.162)

Segundo Helena, esse espaço de diálogo cultural entre as pessoas vai desaparecendo na contemporaneidade: “[...] tudo no mundo era fragmentário, as pessoas não formavam comunidades e só havia valores de troca.”. A arte, uma vez que não é discutida nas comunidades interpretativas, torna-se, cada vez mais, instrumento de massificação e objeto de troca, sem valor genuíno.

O romance, como gênero que acolhe a crítica a esta sociedade moderna e contemporânea, apresentar-se-á fragmentado como o indivíduo desta mesma contemporaneidade. Exemplo flagrante deste romance fragmentado é a obra $O$ Silêncio, já referida na introdução sobre o universo ficcional de Teolinda Gersão.

Júlia, ao contrário, estabelece com a arte musical uma relação de interatividade, retomando o ideal romântico de busca da aura da arte, realizando sua releitura das diversas partituras como uma intérprete que a todo momento reinventa a música.

Mas ela não representa somente a intérprete musical, pois também serve de projeção do leitor que nela está idealizado por Gersão. O leitor, assim como Júlia, deve interpretar as obras como quem executa uma partitura, ou seja, deve estabelecer uma relação de vivência com a obra de arte literária. Logo, ele deve sair dessa relação coletiva, massificada, e passar a perceber que a relação entre a obra de arte e o espectador-ouvinte se dá, exclusivamente, de forma íntima e pessoal, e não de forma massificada.

Nesse momento, a metáfora da trapezista parece aqui superada: no início do livro, quando Júlia vê a trapezista sobre a corda, ela crê que seus olhos mantêm a trapezista em equilíbrio e, portanto, não pode deixar de olhar para a corda para que a trapezista não caia. "[...] Se deixassem de olhar ela caía, ocorreu-lhe. Era o olhar deles que a mantinha equilibrada lá em cima.” (GERSÃO, 1999, p. 34.). No entanto, ela cresce e descobre que a relação entre a trapezista e a corda se dará única e exclusivamente entre as duas, e não depende do olhar da plateia. Tal metáfora pode ser relacionada ao leitor e ao escritor. Eles são independentes, a relação entre eles é 
estabelecida a partir da obra de arte literária, mas as opiniões, leituras e releituras da mesma obra serão, necessariamente, diferentes. Pois, no ideal elaborado por Gersão, o leitor seria o intérprete tocando a partitura, portanto correndo os mesmos riscos, como já foi explicado no primeiro capítulo.

Apesar de pertencerem a diferentes universos, Júlia e Helena estavam unidas por suas relações com um teclado, eram transformadas por um teclado. Nesse sentido, ambas não obedeciam à ordem estabelecida, reinventando seus mundos e relendo as artes musicais e literárias sob seus olhares.

Portanto, Helena simboliza a escritora (Gersão) que cria Júlia e, ambas, numa relação entre criadora e criatura, compartilham uma reflexão sobre a forma leviana como se estabelece a relação do leitor/intérprete com o texto/partitura, aos olhos de um público pouco comprometido com a produção de sentido.

Para aprofundar essas reflexões, tem-se adiante a análise dos elementos musicais e o diálogo entre Literatura e Música em Os Teclados. 


\section{CAPÍTULO III}

\section{O CAMINHO DAS NOTAS}

MUSICAIS -

$1^{\mathrm{a}}$. PARTE: MELODIA 


\section{CAPÍtULO III}

\section{O CAMINHO DAS NOTAS MUSICAIS:}

\section{1ª. PARTE: MELODIA}

\subsection{O diálogo entre as artes: Literatura e Música}

Segundo o filósofo T. W. Adorno, o diálogo entre as artes constitui a característica fundamental da chamada "arte moderna"17. Contudo cada arte deve evoluir com o seu material e a sua lógica própria, mantendo, no "jogo artístico" moderno, cada uma a sua autonomia. Assim, em situação de diálogo, a par da coexistência entre as artes, individualmente, há, também, uma terceira arte, a moderna, sendo a interação artística a base para a sua formação.

Adorno cita o exemplo do quadro Guernica, de Picasso, que reconstrói, para melhor denunciá-la, a realidade de um fato histórico, justapondo os fragmentos de rostos humanos ou de animais. Este princípio de montagem-desmontagem, construçãodesconstrução da forma artística tradicional para aumentar sua expressividade pode ser encontrado em outras artes, quer se trate de literatura, cinema, fotografia ou escultura. Dessa forma, ele afirma a autonomia radical da arte moderna com relação à realidade.

Atualmente, assiste-se ao produto dessa simbiose da arte moderna, com artistas que sonham com uma "polissensorialidade" que reate, de forma nostálgica, a "obra de arte total" e se esforce para unificar a esfera estética. Assiste-se às aproximações, às conjunções, aos intercâmbios entre os diversos procedimentos artísticos, antes especializados em suas artes, atualmente, associados uns aos outros sob o signo artístico. Talvez a arte contemporânea se preocupe mais em conjugar as práticas artísticas, associar matérias heterogêneas do que em classificar e ordenar o domínio do imaginário e do sensível.

Nesse contexto da arte contemporânea está inserida a obra de Teolinda Gersão, que, também por meio de um diálogo entre as artes, busca encontrar um novo padrão de

\footnotetext{
${ }^{17}$ JIMENEZ, Marc. O que é estética? São Leopoldo: UNISINOS/FOCUS, 1999.
} 
escrita e romper com a linguagem tradicional do romance português anterior à Revolução dos Cravos.

A ficção de Gersão, surgida no contexto histórico pós-revolucionário, repensa a identidade portuguesa em um outro contexto, num espaço não propriamente geográfico (Portugal), mas sim o espaço literário (o romance). Texto e contexto se complementam no trabalho de reconstrução de uma identidade nacional ofuscada pela ditadura salazarista.

Segundo Dias (2008), aparentemente a literatura da pós-revolução oferece-se como uma geradora de pluralidade de soluções criativas, de forma indisciplinada; no entanto, há o reflexo do compromisso com uma História, da qual é impossível se distanciar ao escrever. Esse contexto existe por toda a obra de Teolinda Gersão como motivo latente que aflora pela e na escrita.

A luta contra os sistemas dominantes perpassa todas as obras de Gersão via diversas formas de intervenção construídas por meio do discurso narrativo. Nele, quanto mais as personagens femininas se sentem oprimidas, mais a linguagem trabalha esteticamente formas de recusa deste sistema opressor. E a arte, de modo geral, como recusa, torna-se um meio pelo qual a linguagem literária, através de um diálogo com outras artes, rompe a linearidade da narrativa, por meio de recursos estéticos como a montagem-desmontagem, a fragmentação de personagens ou narrativas, estabelecendo também uma fragmentação dos pensamentos do leitor.

A pluralidade de soluções criativas tenta representar o mundo caótico em que vivem as pessoas, traduzindo em suas narrativas a fragmentação do indivíduo presente nesta sociedade contemporânea. Essa fragmentação do indivíduo se multiplica via diversas linguagens impressas no espaço da Literatura. Assim, a página em branco torna-se palco para o diálogo das artes, que tenta compreender, por meio da reflexão estética, o individuo contemporâneo e seu universo social.

Esse diálogo entre as artes é inserido nos primeiros romances de Teolinda por meio do elemento da personificação de objetos do cotidiano, manifestando-se em diversos níveis e ganhando inúmeras significações. Uma dessas significações é desmontar, ironicamente, o mecanismo lógico em que a imagem está inserida. Essa desmontagem da lógica cria imagens que se aproximam do surrealismo de Salvador Dali, “reproduzida plasticamente em seu famoso quadro 'A persistência da memória' (1931), onde relógios amolecidos tomam a forma do espaço em que estão colocados" (DIAS, p. 68). 
Uma outra obra em que o diálogo entre as artes se dá de forma bem evidente é Os Teclados (1999). Nesta obra, Literatura e Música dialogam para constituir a personagem central, Júlia, como sujeito em formação, em aprendizagem.

É por meio das associações entre Música e Literatura, artes que se estruturam sobre a linha do tempo, que o leitor é inserido no universo íntimo da protagonista, sendo levado a refletir, não só sobre a formação dessa personagem, mas também sobre a condição atual da linguagem como história de uma nova escrita e de sua própria condição como sujeito-leitor.

Cada elemento musical presente na obra causa um efeito estético no leitor, fazendo com que este pondere mais intensamente, a partir de sua interação com o texto, sobre as intuições de Júlia acerca da música, da arte literária, de sua família e do cosmos. Do mesmo modo, o leitor passará por momentos de intuição e reflexão similares envolvendo a constituição de um segundo sujeito, o sujeito-leitor.

\subsection{Os elementos musicais na obra Os Teclados}

Como já foi mencionado, Júlia é introduzida, logo na abertura do romance, como aquela que "Em criança [...] rezava por Mozart" (GERSÃO, 1999, p. 08). Esta primeira frase do romance leva o leitor à possibilidade de um diálogo entre as artes dentro da narrativa. Ao longo da leitura, esse possível diálogo vai sendo confirmado quando o leitor se depara com a citação de grandes musicistas, tais como Mozart, Beethoven, Bach, bem como palavras que o remetem ao universo da música, como stacatto, alegretto, violinos, violoncelos, piano, teclado, partitura, clave, entre outras.

Observa-se que, no texto, a presença da música não se limita ao nível temáticointerpretativo, mas pode ser reconhecida no próprio tecido da narrativa, no seu nível estrutural. É possível constatar, a partir de certos recortes d'Os Teclados, que este trabalho versará, entre outros aspectos, sobre a semelhança entre a estrutura narrativa e a estrutura musical. O leitor estará diante de estruturas que lembram andantes, alegrettos, pianíssimos, retardamentos, sonatas e, portanto, diante do diálogo artístico entre Literatura e Música, sendo que nenhuma das duas artes se anula. Ao contrário, em cada momento uma está em função da outra, destacando-se os elementos peculiares de cada uma, mantendo-se, assim, a autonomia destas artes. 
Para compreender as relações que ocorrem no plano estrutural, os termos "música de palavras" e "música verbal" serão utilizados ao longo da análise. Steven Paul Scher apresenta tais denominações da seguinte maneira: "música de palavras" refere-se à prática literária de imitar a qualidade acústica da música por meio de recursos como onomatopeias, aliterações e assonâncias; "música verbal" consiste na apresentação (em prosa ou poesia) de composições musicais, reais ou fictícias, ou ainda, de qualquer textura poética que tenha como tema uma composição musical. Por exemplo, logo no início, o narrador põe o leitor diante da presença da "música verbal". Trata-se do momento em que Tio Octávio se irrita ao ser interrompido por um barulho no momento em que estava ouvindo Beethoven:

[...] Estafermos, diziam os violoncelos. Não pode um homem ter um minuto de sossego em sua casa sem vir um cretino estragar tudo. (Sem vir um cretino estragar tudo, repetia, mais alto, o primeiro violino, numa voz aguda). Vão para o inferno, vão para o inferno, ameaçavam, em coro, os contrabaixos. (GERSÃO, 1999, p.08).

A descrição da irritação de Tio Octávio aparece diretamente relacionada aos instrumentos musicais. Cada instrumento aparece e desaparece, como se o conjunto deles compusesse uma orquestra sendo regida. O primeiro violino comanda toda a orquestra, assim como Tio Octávio crê que comanda a casa em que Júlia vive. O movimento dos gritos da personagem e a voz dele sobressaindo-se às outras são representados por meio das palavras que sinalizam o timbre de cada instrumento, como se vê a partir dos termos sublinhados: "(Sem vir um cretino estragar tudo, repetia, mais alto, o primeiro violino, numa voz aguda). Vão para o inferno, vão para o inferno, ameaçavam, em coro os contrabaixos". (GERSÃO, 1999, p.08, grifo nosso).

Como toda a obra está estruturada por meio de elementos musicais, como tom, timbre, harmonia, acordes, refrões, notas, entre outros, cabe a este capítulo apresentar, passo a passo, os conceitos musicais de que esta análise se valerá, pois só assim será possível compreender o diálogo artístico entre Literatura e Música na obra em questão.

A narrativa d'Os Teclados está estruturada como uma partitura musical. Em uma partitura, veem-se duas linhas básicas delimitadoras: a linha em que a melodia é expressa e a linha em que a harmonia se apresenta. Cada uma destas linhas deve seguir um tom indicado no início da partitura. A partir deste tom, todo conjunto de notas 
obedece a alguns arranjos possíveis, como uma determinada sequência de notas ou um acorde que acompanha determinada nota devido ao tom.

A narrativa segue essa mesma organização de uma partitura. Há uma linha melódica que passa por todo o romance, bem como uma linha harmônica cujos acordes, a partir do tom já indicado na primeira linha do romance, acompanham a melodia traçada desde o início, também determinada pelo tom.

Para definir os conceitos musicais a seguir, utilizou-se o Dicionário Musical Brasileiro, de Mario de Andrade.

\subsubsection{A Tonalidade}

Tonalidade, em um sentido amplo, é a organização da música em torno de uma determinada nota, chamada tônica, que serve como ponto focal. Sem o tom não há música. Uma vez escolhido, a partir dele, toda a partitura musical é escrita. Logo, o primeiro elemento musical que deve ser escolhido para a composição de uma música é o tom no qual a partitura será tocada. A partir dessa escolha, organizam-se a melodia, o compasso, os acordes etc. - o tom, enfim, decide tudo. Segue a definição de tom: "Tom (s.m.) Intervalo de segunda maior na escala cromática temperada, equivalente à soma de dois semitons". (p.523) ${ }^{18}$. Ou ainda, complexo de sons estabelecido sobre as escalas maiores e menores e sobre o número dos acidentes na armação da clave, que atinge a cinco sustenidos e a cinco bemóis (semitons).

A partir da definição da nota tonal constroem-se todas as demais estruturas musicais da partitura, como a harmonia, por exemplo. Dentro da narrativa d'Os Teclados, o narrador expõe que o romance também se organiza como a música, uma vez que ambas as artes se organizam no tempo. Assim como as partituras, o romance também precisa de seu tom que, conforme nos explicita a voz narrativa de Os Teclados, é escolhido em sua primeira frase: "Havia como na música uma liberdade e um determinismo - a última frase de um romance, por exemplo, estava já contida na primeira. Era sempre o tom que decidia tudo. Uma vez encontrado era como uma chave.

\footnotetext{
${ }^{18}$ ANDRADE, Mario de. Dicionário Musical Brasileiro. Belo Horizonte Itatiaia, 1999.
} 
Uma clave.” (GERSÃO, 1999, p. 52). O tom expresso no início da partitura ou do romance é a grande "chave" para se compreender uma obra musical ou literária, ou ainda, a indicação da interpretação do texto e da partitura por meio da interpretação da clave.

Em Os Teclados, o tom já é anunciado em sua primeira frase "Em criança ela rezava por Mozart” (GERSÃO, 1999, p. 07), daí ser possível considerar essa assertiva como início de um diálogo artístico entre Música e Literatura dentro da narrativa, diálogo este já apresentado ao leitor desde o início. Por conseguinte, o tom da narrativa perpassa a simbiose entre as artes: Literatura e Música.

\subsubsection{As claves em Os Teclados}

No início da obra, a já mencionada descrição da irritação de Tio Octávio passa pela elaboração de som que poderia ser representada pelas duas claves: de Sol e de Fá.

Antigamente, para representar as vozes humanas em uma partitura se utilizava a Clave de Dó. No entanto, atualmente, esta clave costuma ser empregada apenas nas partituras em que o instrumento utilizado seria a viola ou em partituras antigas que ainda representam alguns instrumentos e as vozes humanas por meio desta clave.

Hoje, para representar as vozes humanas em partituras, assim como os instrumentos, também se utilizam a clave de Sol (vozes agudas) e a clave de Fá (vozes graves). Na narrativa d'Os Teclados, há uma sobreposição interpretativa, pois a descrição dos instrumentos é utilizada para representar os timbres percebidos nos gritos de Tio Octávio. Esta mistura de instrumentos, timbres, sobreposição e intercalação de sons remete o leitor à regência de uma orquestra, cujo maestro é o narrador. Logo abaixo, segue o trecho completo representando esta orquestra, regida pelo narrador em consonância com a leitura colérica que a personagem estabelece de um determinado trecho exaltado da sinfonia que está a ouvir:

[...] Estafermos, diziam os violoncelos. Não pode um homem ter um minuto de sossego em sua casa sem vir um cretino estragar tudo. (Sem vir um cretino estragar tudo, repetia, mais alto, o primeiro violino, 
numa voz aguda). Vão para o inferno, vão para o inferno, ameaçavam, em coro os contrabaixos. (GERSÃO, 1999, p.08).

Neste trecho, portanto, tem-se a chamada "música verbal", cuja estrutura musical é utilizada pela literatura para causar um efeito sobre o leitor a partir da descrição do som dos gritos de tio Octávio.

\subsubsection{A tonalidade e a clave}

A tonalidade musical é expressa a partir de uma clave, podendo esta ser de Sol, de Fá ou de Dó, como já explicitado. Por conseguinte, a clave indica qual leitura da partitura deve ser realizada, ou seja, em qual tonalidade o musicista deve tocar.

Por isso, diz-se que a clave é a "chave" para se compreender a partitura. A este respeito lê-se em Os Teclados:

Havia como na música uma liberdade e um determinismo - a última frase de um romance, por exemplo, estava já contida na primeira. Era sempre o tom que decidia tudo. Uma vez encontrado, tornava-se uma chave. Uma clave. Nos verdadeiros romances o essencial era, até certo ponto, previsível. (GERSÃO, 1999, p. 52).

O romance também possui a sua clave, ou seja, a "chave" para que o leitor compreenda a narrativa. Esta, geralmente, é apresentada nas primeiras linhas do romance. Nesta obra de Teolinda, a "chave" (ou a "clave") pode ser encontrada a partir do diálogo intersemiótico que percorre a narrativa. Contudo, se o musicista não souber ler a clave em que a partitura está sendo escrita e, portanto, não compreender a tonalidade em que a partitura está sendo elaborada, torna-se impossível a execução musical. Bem como, se o leitor não souber qual a "tonalidade" do texto lido, a 
interpretação será dificultada ou até impossível de ser realizada. Logo, entender a tonalidade do texto é parte fundamental para a elaboração do ato interpretativo.

\subsubsection{A tonalidade musical e a literária}

A tonalidade musical, servindo aqui como elemento de comparação para pensar a construção literária, funciona como uma atitude interrogante, reflexiva, conduzida pelos pensamentos da protagonista. Como já foi dito, cada criação literária segue um fio condutor narrativo, que funciona como tom "musical" do texto e que já está presente desde as primeiras frases do romance. A partir desta escolha, assim como o musicista, o autor já tem um caminho traçado pelo tom.

As intuições de Júlia em busca de uma "Verdade" ou a partir da análise de seu ambiente familiar, seu contato com os professores, a entrevista com a escritora Helena Estevão e a linguagem musical são o "tom literário" deste romance. Júlia está, estigmatiza-o como, em busca de um sentido para a existência. Conforme cresce, esta "Verdade" vai sendo "encontrada" em algo ou alguém. Todavia, a protagonista percebe que aquele objeto, pessoa ou teoria não encerra um sentido perene, como ela havia acreditado e, então, ela prossegue em busca deste sentido precioso, e a cada nova vivência, surge um novo possível lugar para essa "Verdade", ou seja, o grande sentido procurado por ela é o tempo todo mutável.

Ao fim do romance, Júlia percebe que a "Verdade" não existe como sentido dado, pronto e fechado, como um segredo à espera de uma decifração definitiva, não se encontra em algo ou alguém. Por isso, ela senta em frente a uma plateia vazia e, mesmo assim, toca; tendo aprendido que o sentido que buscava está dentro de si e não no exterior, não há motivo para não tocar, pois a música em si já tem um pouco do sentido buscado por ela. No trecho a seguir, Júlia se confronta com a certeza de que a "Verdade", tal como ela acreditava na primeira frase do romance, "Em criança ela rezava por Mozart” (GERSÃO, 1999, p.07), não está mais em Mozart, aliás, não está em nenhum lugar, porque o sentido é algo construído no âmbito do sujeito: "Mas talvez nem isso pudesse ser pensado. $\mathrm{O}$ universo esvaziara-se de sentido, o mundo perdera a transcendência. Não existia milagre em parte alguma.” (GERSÃO, 1999, p. 94). 
O leitor pode constatar que Júlia modificou o seu conceito em relação à grande "Verdade" da vida, pois agora percebe que não existe um sentido dado que comanda o universo e a vida de cada ser, mas uma série de acontecimentos que influenciam essa existência. Simultaneamente, o leitor percebe que o "tom" do romance permanece o mesmo, as intuições de Júlia acerca do mundo, de sua casa, do teclado, ocasionados por meio do diálogo entre a linguagem musical e a literária. A partir dessas intuições, Júlia constitui-se como sujeito que, por sua vez, constrói sentidos para a sua existência, na medida em que lê (interpreta) o mundo.

Como o romance está estruturado como uma partitura musical, uma vez encontrado o tom, é preciso analisar as duas linhas que delimitam a partitura: a linha melódica e a linha harmônica.

\subsubsection{A Melodia}

Para tanto, convém explorar o conceito de melodia. Segundo o Dicionário Musical Brasileiro, "Melodia é a organização de sons musicais combinando diversos intervalos e valores rítmicos" (p. 329). ${ }^{19}$.

Melodia, na música, é a sucessão de sons isolados e combinados em alturas e valores diferentes que obedecem a um sentido lógico musical. Na grafia musical, ela se apresenta em direção horizontal e é constituída de frases e períodos. Dois ou três $\operatorname{compassos}^{20}$ formam uma frase musical.

$\mathrm{Na}$ primeira linha da partitura, na posição horizontal, está representada a melodia, cujas notas seguem o tom já indicado pela clave de sol no início da partitura, assim como o compasso quaternário (4/4).

Segue abaixo outra definição de melodia, extraída do livro Literatura e Música, de Luiz Piva:

A melodia, como uma sucessão de sons de distinta altura, por oposição à sua audição simultânea, é elemento de primacial importância no discurso musical. Ernst Toch considera a melodia

\footnotetext{
19 Ibid.

${ }^{20}$ Compasso: a métrica da música tem origem no período do Mensuralismo, quando as figuras começam a adquirir um valor determinado, constituindo, em seguida, a formação de agrupamentos de vários ritmos e, para facilitar a leitura, foram inseridos entre duas pequenas barras de divisão. Dessa evolução surgiram diversas espécies de compassos simples e compostos; divididos em Binário, Ternário e Quaternário. (PLATZER, Frédéric. Compêndio de Música. Lisboa: Edições 70.
} 
como o produto da reunião de ritmo e linha de altitudes. A melodia pode ver-se reduzida a uma só figura repetida continuamente durante certo espaço de tempo, não só em casos de intenção deliberada, mas também quando da mais elevada inspiração (p. 50) ${ }^{21}$

Na narrativa, as reflexões de Júlia conduzem à linha melódica, marcando-a como autorreflexiva. Cada reflexão sobre o mundo, sobre os elementos musicais, sua família, os professores, o universo, o diálogo entre as artes - Literatura e Música - por meio da análise do suplemento do jornal com a entrevista da escritora Helena Estevão, a loucura e a incomunicabilidade humana, o mercado editorial, cada um desses tópicos, enfim, corresponde a um "fraseado melódico" que forma essa melodia. Todas as notas formam o tecido musical/literário do romance, e elas, por sua vez, obedecem ao "tom", que é a busca pela "Verdade" sobre a vida, conduzindo a protagonista à sua constituição enquanto sujeito. Simultaneamente, através da leitura, outro sujeito vai gradativamente constituindo-se: o leitor. Essa linha melódica é construída, predominantemente, em discurso indireto e indireto livre, com intervenções menores de discurso direto dos personagens. A seguir, um exemplo da linha melódica de Teclados, com algumas das reflexões de Júlia:

Nessa época tio Octávio ouvia sinfonias e concertos sentado na poltrona ao canto da janela, arrancando pêlos da orelha e palitando os dentes. Praguejava sempre que alguém inadvertidamente, abria a porta, batia com o punho na mesa de camilha como se tentasse afugentar, pelo barulho, o intruso que entretanto retrocedera rapidamente e desaparecera na profundidade do corredor. (GERSÃO, 1999, p.07).

A linha melódica do romance se inicia com a contraposição dos dois compositores já referidos no primeiro capítulo, Beethoven e Mozart. Beethoven é apreciado por Tio Octávio, enquanto Mozart é o ídolo de Júlia. Nesse debate silencioso, Júlia inicia sua trajetória de reflexões sobre seu núcleo familiar. Passa, primeiramente, pela figura do tio Octávio, que representa a autoridade máxima, o opressor, de certo

\footnotetext{
${ }^{21}$ PIVA, Luiz. Literatura e Musica. Brasília: MusiMed, 1990.
} 
modo. Ele detesta ser interrompido quando está ouvindo suas músicas, em especial, de Beethoven. No trecho "[...] Praguejava sempre que alguém inadvertidamente, abria a porta, batia com o punho na mesa de camilha como se tentasse afugentar, pelo barulho, o intruso [...]", percebe-se o uso de uma certa forma de violência, através das batidas dos punhos sobre a mesa, para afugentar aquele que o interrompera, violência empregada para manter, segundo sua perspectiva, a ordem no lar.

Seguindo a linha melódica, Júlia inicia nova reflexão sobre o ato de ouvir, uma vez que em sua casa predomina o silêncio. Tem-se, então, o tema da incomunicabilidade humana emergindo no texto. Tia Isaura e Armênia são parcialmente surdas, Tio Octávio não escuta ninguém, somente as suas próprias ordens, Tio Eurico vive em seu mundo particular, alheio à casa; ela, Júlia, tranca-se no quarto para tocar um piano de papel e ouvir apenas o silêncio: enfim, o ato de ouvir (e sua importância) é o segundo fraseado melódico" entoado por Júlia em sua "partitura/literária".

No fragmento a seguir, algumas concepções sobre o ato de ouvir, reconhecidas pela protagonista nos seus momentos de reflexão:

Ouvir era um segredo. Ela ouvia muitas coisas, algumas impossíveis. Por exemplo, bastava-lhe olhar a pauta para ouvir a música lá escrita. [...] Não apenas um instrumento, violino ou piano, tinha a certeza de que poderia ouvir toda uma orquestra a partir da música escrita. (GERSÃO, 1999, p.13).

Ouvir era um risco para Júlia, pois esse era um ato de entrega. A Música, assim como a Literatura, acontecia pelo ato de ouvir. A primeira pela audição da sequência de notas, a segunda pela audição da leitura. Observa-se isto no seguinte trecho:

Ouvir era deixar o mundo entrar em si. Ficava sem defesa, escutando. O som seguia o seu curso e ela deixava de existir separadamente, tornava-se parte do que acontecia. O que era também um risco. Quase de morte, pensava às vezes. Porque a música, de algum modo, estilhaçava-a, fazia-a sair de si mesma e arrastava-a para um estágio indiferenciado, não humano, contra o qual a música finalmente triunfava. (GERSÃO, 1999, p.16) 
Uma vez ouvida a melodia de uma música, esta, inevitavelmente, invade o ser de quem ouve e o transforma, em menor ou em maior grau, mas o ouvinte nunca será o mesmo após a experiência da audição, “[...] O som seguia o seu curso e ela deixava de existir separadamente, tornava-se parte do que acontecia" (p.16).; a música, por meio da experiência estética, tem o poder de transformar o ser "[...] Porque a música, de algum modo, estilhaçava-a, fazia-a sair de si mesma e arrastava-a para um estágio indiferenciado, não humano, contra o qual a música finalmente triunfava." “[...] (p.16). Assim também o leitor, após o ato da leitura, não é mais o mesmo, mas um outro, a quem a experiência literária acrescentou novas vivências.

Permanecendo na linha melódica, Júlia muda novamente sua reflexão, detendo-se agora em Tio Eurico, o "Tio eu”:

[...] O tio Eu. O tio eu.

A ideia de que era igual a ele, de que podia enlouquecer como ele. Também ela fugia de casa, vagueava pelas ruas, se fechava no quarto, escondia segredos. Também a ela alguma coisa a assaltava, a música era uma onda de energia desencadeada e solta, à mercê da qual ficava sem defesa. O tio eu. (GERSÃO, 1999, p.40).

Tio Eurico funciona no livro como um "espelho" do "eu" de diversos personagens, em especial de Júlia e Octávio. Octávio vê em Eurico seu "eu” destroçado e, por não aguentar tal projeção, trata com violência e vergonha o cunhado, trancando-o em casa ou mandando Júlia buscá-lo nas ruas quando ele foge. Por outro lado, Júlia projeta no "espelho Eurico" seu receio, de forma mais consciente, em relação à loucura. Eurico não domina o discurso, não fala, por isso, segundo ela, teria enlouquecido. Júlia pouco fala ao longo da narrativa, e seu silêncio esconde o medo de também enlouquecer, como Eurico, “[...] A ideia de que era igual a ele, de que podia enlouquecer como ele. [...]" (p.40).

Seguindo a linha melódica, Júlia pensa em sua tia Isaura. Isaura é uma dona de casa, atormentada pelo marido Octávio, que deseja sempre tudo em ordem, não aceita seu irmão Eurico e ainda a obriga a manter as obrigações conjugais de tocarem juntos ela e Octávio. A relação problemática entre Octávio e Isaura e a ausência de diálogo entre ambos estão simbolizadas na execução musical, em que Isaura sempre erra os mesmos acordes e Octávio se irrita, terminando a execução sozinho em um gesto de 
triunfo solitário. O trecho a seguir revela esta falta de comunicação entre Octávio e Isaura:

\begin{abstract}
Voltava-se para ela, torcendo a cabeça e os ombros e levantando de vez em quando as sobrancelhas, a tia corava, cada vez mais ansiosa, enganava-se sempre nos mesmos acordes, repetia e parava, às vezes desistia. O tio enervava-se, batia com o pé, enquanto a tia arquejava, quase à beira das lágrimas. Então, o tio desembaraçava-se completamente da tia e terminava sozinho: no final improvisava, friccionando o arco em todas as direções, como se quisesse polir as cordas do violino. (GERSÃO, 1999, p. 23).
\end{abstract}

Assim, a música, que, a princípio, foi o elo de união entre ambos, agora é vista como uma tortura, uma obrigação matrimonial cujo cumprimento humilhava Isaura, por conta de seus constantes erros: "[...] enganava-se sempre nos mesmos acordes, repetia e parava, às vezes desistia. O tio enervava-se, batia com o pé, enquanto a tia arquejava, quase à beira das lágrimas [...]” (p.23).

A linha melódica passa pelas reflexões sobre os professores de Música: Palrinha e Severiano Mendonça. O primeiro representa a liberdade criativa que, como incentivador de Júlia, permitiria o seu toque livre sobre o teclado. No entanto, o mestre Palrinha não representa um vitorioso na vida. O segundo desencadeia as reflexões críticas da protagonista acerca do mercado artístico. Ele quer evidenciar seu nome nas capas de suas apostilas de partituras, de modo a sobrepor-se aos compositores.

Em dado momento da melodia que está se formando, uma nota se destaca, aquela que representa as intuições de Júlia após ler a entrevista da escritora Helena Estevão e suas reflexões sobre literatura, autor, leitor e o mercado artístico. A partir desse instante, o diálogo entre as artes - Literatura e Música - toma uma dimensão ainda maior no que diz respeito à estrutura do romance, pois ultrapassa o nível estrutural do texto e alcança o nível macroestrutural (contextual, de teor metalinguístico), em que Júlia reflete sobre o papel da arte, do ouvinte e do intérprete. No trecho a seguir, Júlia lê a reflexão de Helena sobre o leitor idealizado por ela e, também, sobre o mercado artístico: 
Ela gostaria de pensar que o leitor era como o escritor, de certa maneira a sua outra face, disse a mulher: Aceitava os mesmos riscos, passava as mesmas noites em claro, tropeçava nos mesmos escolhos, sonhava os mesmos sonhos. Para depois reagir contra eles. Reinventava o livro, como o intérprete tocando a partitura. Por vezes numa direção muito diferente. Era verdade que ela gostava - ou gostaria - de pensar isso, repetiu depois de um silêncio, Mas num mundo em que os valores eram de troca, tudo se tornara de certo modo indiferente. $\mathrm{O}$ leitor, como o escritor, tornara-se uma personagem rara. (GERSÃO, 1999, p. 55).

Júlia pensa nas palavras de Helena Estevão sobre o mercado, o mundo voltado apenas para a troca comercial e não para o conhecimento. Encontrar um verdadeiro intérprete, assim como um verdadeiro leitor torna-se raridade. O questionamento se dá pelo papel da arte nesta nova sociedade, que valoriza a informação em detrimento do conhecimento: “[...] Mas num mundo em que os valores eram de troca, tudo se tornara de certo modo indiferente. O leitor, como o escritor, tornara-se uma personagem rara"(p.55).

A melodia do texto é finalizada pela reflexão de Júlia sobre o cosmos:

Havia relação entre a estrutura do cosmos e a da música. A primeira música era a de cada planeta. O movimento dos planetas era música, a música era o princípio de tudo, a expressão de poderes superiores que governavam o mundo. Cada corpo celeste possuía uma nota e um acorde específico, o conjunto traduzia a harmonia do universo. Aqui em baixo, na terra, só o ouvido subtil a podia alcançar: através de tudo que existia, podia ouvir-se com esse ouvido interior, a harmonia superior que governava o mundo. (GERSÃO, 1999, p. 72).

Como se depreende da leitura do fragmento, Júlia acredita que a "Verdade" sobre a vida está na música, que teria organizado todo o universo, "[...] O movimento dos planetas era música, a música era o princípio de tudo, a expressão de poderes superiores que governavam o mundo. [...]" (p.72), porém, nesse instante dos pensamentos de Júlia, percebe-se uma mudança no ato reflexivo, pois, agora, ela se utiliza de explicações filosóficas que partem de teorias matemáticas, de base racional, para pensar o universo; diferentemente do que ela estava fazendo até então na narrativa, 
uma vez que refletia a partir de suas intuições e observações pessoais sobre o mundo ao seu redor.

Em seguida, na melodia, Júlia percebe que não há a grande "Verdade" como ela acreditava, uma vez que, ao longo de seu crescimento, esta "Verdade" vai sendo projetada ora em uma pessoa, ora em um objeto, ora em uma teoria. Nesse momento, o leitor pode reconhecer, nessa percepção de Júlia, uma demonstração de que ela amadureceu e se defrontou com o mundo adulto, e que a perspectiva pela busca da "Verdade" se modifica. Compreende, então, que não há uma "Verdade" única, mas sim uma transformação constante de um sentido que se constrói a cada leitura e/ou execução.

Toda essa trajetória explicita a linha melódica presente no texto. Observa-se que, nas reflexões intuitivas ou racionalizadas de Júlia acerca do mundo, do fazer artístico, de sua família, que o tom é mantido por meio dos elementos musicais.

Em paralelo a esta linha melódica, horizontalmente construída na narrativa da obra Os Teclados, tem-se a linha harmônica, cuja construção se dá através da verticalidade, em termos textuais. Trata-se da "música verbal". A linha harmônica é fundamental para que o intérprete enfatize sua visão da música executada, e parte essencial para que o compositor destaque os momentos que devem ter mais atenção do ouvinte. Nesse sentido, é na linha harmônica d'Os Teclados que o leitor exercitará seu poder de interpretação, aprofundando-se na leitura e compreensão da obra. Esse é o tema do próximo capítulo. 


\section{CAPÍTULO IV}

\section{O CAMINHO DOS ARPEJOS}

MÚSICO-TEXTUAIS D' $O S$

TECLADOS $-2^{\mathrm{a}}$. PARTE:

HARMONIA 


\section{CAPÍTULO IV}

\section{O CAMINHO DOS ARPEJOS MÚSICO-TEXTUAIS D'OS TECLADOS - 2a PARTE: HARMONIA}

Além da linha melódica, apresentada no capítulo anterior, a narrativa d'Os Teclados também possui uma linha harmônica, que completa a "partitura" do livro. Ela é formada pelos "acordes" que destacam as intuições de Júlia em relação à sua casa, à sua escola e ao mundo ao seu redor. As notas presentes nesses acordes são representadas tanto por personagens como por frases repetidas ao longo da narrativa, visando chamar a atenção para o significado delas ou ainda para as reflexões que suscitarão no leitor.

Para se compreender melhor a elaboração harmônica construída pela autora, é necessário entender, primeiramente, um outro conceito: o contraponto.

Segundo Magnani (1996),

O contraponto é a sobreposição de duas ou mais linhas melódicas, cada uma das quais mantém sua independência. Como as primeiras experiências foram realizadas acompanhando cada nota de uma melodia com uma nota da outra, a saber, nota contra nota, $(\mathrm{em}$ latim $=$ punctus contra punctum), o termo contraponto passou a designar este tipo de linguagem musical [...]. (p.86).

A técnica de contraponto consistia na arte de conjugar, em planos diferentes, duas, três ou mais melodias de natureza diversa, que deviam combinar harmonicamente entre si, embora se mantivessem independentes. A essa articulação de notas melódicas distintas também se deu o nome de polifonia. (ANDRADE, 1999, p.154). O contraponto harmonizaria, portanto, vozes diversas que estariam compondo uma melodia. Entretanto, o contraponto, na história, acaba sendo expulso da música vocal e encontra seu último refúgio na estrutura instrumental da Fuga. 
Em Os Teclados, os acontecimentos da vida de Júlia conduzem a melodia do livro, enquanto as vibrações interiores (reflexivas) de sua consciência marcam a linha harmônica. As diversas intuições de Júlia acerca das relações sociais dentro de sua casa, a música, as concepções sobre a formação do universo e, ainda, as artes literária e musical integram as muitas vozes que se harmonizam para o processo de constituição do "eu" de Júlia ao longo da narrativa.

Num primeiro momento, todas as personagens que habitam o universo doméstico de Júlia são notas destoantes que se contrapõem. Júlia, como uma regente, lê os movimentos de cada uma delas (as ações, as falas, as relações e concepções) e compõe, a partir desses dados, a música de sua vida. Em razão do seu caráter contrapontístico, essa música - representada pelo universo do lar - lembra, para Júlia, uma fuga de Bach. Por exemplo, no fragmento a seguir, a protagonista reflete sobre as vozes destoantes de sua casa e do mundo e as compara com as vozes de Bach: "As muitas vozes das coisas. Vozes de Bach, jogando umas com as outras, cruzando-se, convergindo, divergindo. Puro jogo, como o do mar e das ondas. Assim o mundo era feito." (GERSÃO, 1999, p.15).

Em síntese, a comparação com a música contrapontística antecipa o requintado jogo de vozes que comporá a linha harmônica do texto a partir do episódio da leitura da entrevista de Helena Estevão, que será retomado mais adiante.

Assim, o contraponto será a base para a elaboração das estruturas harmônicas musicais. Neste romance de Teolinda, elas, pode-se dizer, correspondem às etapas de maior evolução no processo de aprendizagem de Júlia, posteriormente, aos momentos epifânicos que ela vivencia.

Segundo Magnani (1996), o contraponto

é a manifestação mais elevada de um requintado racionalismo do artesanato musical, constituindo-se em técnica indispensável, em qualquer linguagem, para revigorar o movimento interno das partes, fornecer luz e continuidade ao plano da profundidade sonora e proporcionar rigor lógico à sequência do discurso musical. (1996, p.88). 
Historicamente, até o advento da concepção de harmonia, coube ao contraponto garantir que os elementos temáticos percorressem todas as vozes presentes numa determinada composição musical, colocando-as no mesmo plano de importância. Com a introdução do conceito de harmonia, ocorre uma reconstrução da estrutura que acompanha a melodia. Logo, na estrutura harmônica, ao contrário do que se dá no contraponto, há uma hierarquia entre as várias partes dos acordes. Num primeiro plano, a nota auditivamente mais perceptível é aquela que acompanha a linha melódica, ou seja, a melodia acompanhada; em segundo plano, há a voz interior, isto é, a base dos acordes; e, em terceiro, as chamadas partes internas; estas últimas sempre se submetem à lei do baixo contínuo que as sustenta. Este, por sua vez, não será mais uma voz como as outras no jogo contrapontístico - onde era marcado por silêncios que valorizavam as entradas mais interessantes - mas será um contínuo, a base do sentimento harmônico, ou o chamado baixo-contínuo. Em outras palavras, com o advento da harmonia, toda a perspectiva é modificada. Enquanto no contraponto o discurso musical era uma fluência horizontal de sons e silêncios, com a harmonia, a música passa a ser uma estrutura de "pilastras verticais - os acordes - sobre a qual se desenrolam os arcos da melodia acompanhada." (MAGNANI, 1996, p.89).

Em Os Teclados, podem ser vistos momentos harmônicos alternados com momentos contrapontísticos. Estes podem ser percebidos na primeira parte da obra, quando o narrador apresenta, lenta e quase individualmente, as personagens que vivem na casa de Júlia. A cada trecho da primeira parte o narrador se detém em uma delas, explicando seus trejeitos, suas falas, seus sentimentos e revelando seus traços de personalidade por meio da narração de alguns episódios que ela protagoniza.

A descrição de Tio Octávio, por exemplo, lembra uma caricatura. Ele está sentado em uma poltrona, palitando os dentes, tirando pelos da orelha e ouvindo os concertos e sinfonias de Beethoven. Na sequência, o leitor depara-se com a figura de Tio Eurico, personagem com distúrbios mentais, ou seja: uma representação da loucura humana na sociedade contemporânea.

Talvez pelo fato de serem ambos, de alguma forma, figuras paradigmáticas para Júlia, a descrição de tio Octávio e tio Eurico é mais longa que a das demais personagens da casa. Ao mesmo tempo, significativamente, a descrição é intercalada por diversas concepções do ato de ouvir. Explicando melhor, as ações de tio Octávio são permeadas por ruídos ásperos, grosseiros e, além disso, seu modo de ouvir Beethoven, como já se disse, é bastante caricatural. Já tio Eurico só é capaz de identificar a voz de Júlia e a 
música que ela toca ao piano (Camiñito) e o barulho que ele faz com a colher ao bater nos objetos chega a ser ensurdecedor. No contraponto constituído pelo universo familiar, tio Eurico e tio Octávio constituem os acordes mais importantes.

Menos importante que essas duas figuras masculinas da casa é Tia Isaura, mulher submissa ao marido, que sofre com as obrigações do casamento e com o ato de tocar piano, que parece ser, para ela, uma tortura. Interessante o narrador destacar que tanto Isaura quanto Armênia, a empregada da casa, são acometidas de certo grau de surdez e, portanto, alienadas das discussões da casa.

Na sequência, a descrição de Madame Ortega, a professora de música, e de Ireninha, introduz um importante núcleo temático - da recepção musical. Essas figuras integram um tipo de relação com a arte que Júlia rejeitará desde o princípio. Elas participam do primeiro "incidente" que leva Júlia a esconder de tio Octávio seu dom para a música. Um segundo "incidente", que ocorre durante o passeio de Júlia e Ireninha ao circo, é protagonizado pela trapezista, a Senhorita Maciel. Nesse episódio se concentra outro núcleo temático relacionado, metaforicamente, à interação (ou independência) entre autor e público.

Claudemiro Palrinha representa o professor que concede a Júlia autonomia enquanto intérprete ao piano. Trata-se de uma figura ambígua, uma vez que está fisicamente debilitado, não demonstra ter tido grandes realizações na vida e é socialmente fracassado; por outro lado, projeta seu idealismo no incentivo à paixão de Júlia pela arte. Em termos mais amplos, Palrinha pode ser visto como uma representação do papel restrito que coube ao artista ou ao amante da criação artística no espaço da chamada indústria cultural.

Enfim, esta é a apresentação dessas vozes (notas) que irão compor o segmento contrapontístico do livro. Depois, inicia-se uma segunda parte, a partir da entrevista de Helena Estevão. As descrições dos personagens tornam-se, então, menores, ao passo que algumas estruturas frasais, de ordem simbólica ou reflexiva, passam a se repetir constantemente, identificando-se mais à estrutura dos acordes musicais, ou seja, à harmonia.

Em termos mais concretos, observa-se, ao ler o texto desta segunda parte, a execução de acordes textuais ou a chamada música verbal, isto é, estruturas textuais organizadas e articuladas como acordes.

Chama-se, aqui, de acordes às frases que se repetem ao longo do romance e que acabam sustentando sua vibração na linha do tempo. Há uma série de frases que se 
repetem e cujo sentido (obscuro ou incompleto) parece ficar vibrando no texto, como mistérios em busca da decifração que lhes dê repouso, formando a linha harmônica que acompanha sempre a melodia.

Portanto, pode-se dizer que, dentro da harmonia da obra, destacam-se duas linhas de formação harmônica: o contraponto e os acordes.

Para compreender melhor, convém retomar o conceito de Harmonia. O termo harmonia, na música, se emprega tanto no sentido geral de um conjunto de notas ou sons que vibram ao mesmo tempo quanto no de conjunto dos acordes executados para acompanhar a melodia. Segue a definição de harmonia:

Harmonia: Estudo da combinação de notas soando simultaneamente (acorde) e de seu encadeamento.

É a ciência do acorde com suas características intrínsecas, dentro de uma perspectiva vertical, e das relações que estabelecem entre si, dentro de uma perspectiva horizontal. (p. 254) ${ }^{22}$

Harmonia é a ciência que estuda a concatenação dos acordes, ou, ainda, é a combinação das vozes que acompanham a melodia principal. Na grafia musical, ela se apresenta em sentido vertical, executando-se na simultaneidade de sons que vibram em conjunto. Cada acorde tocado, ao acompanhar a melodia, combinar-se-á com o acorde anterior e o próximo a ele e, principalmente, com o tom escolhido no início da partitura. A partitura possui uma segunda linha, onde há a anotação dos acordes, ou seja, a representação da harmonia, como na figura a seguir:

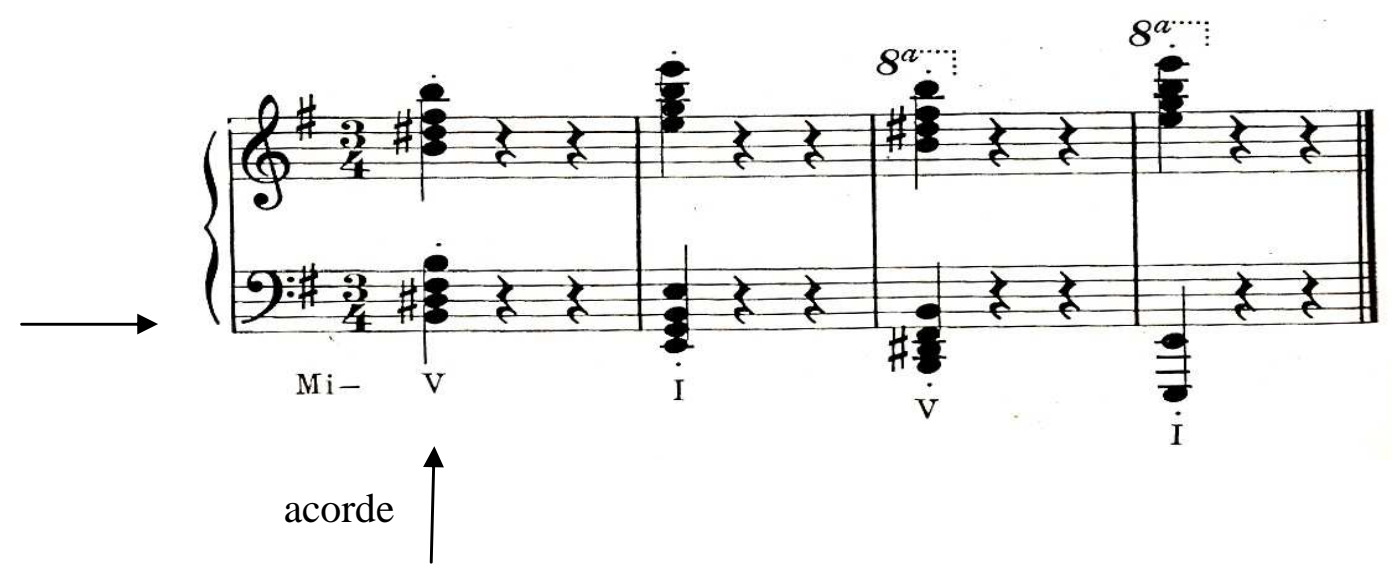

${ }^{22}$ ANDRADE, Mário de. Dicionário Musical Brasileiro. Belo Horizonte - Rio de Janeiro: Itatiaia, 1999. 
Segundo Mário de Andrade, em Pauliceia Desvairada, a "harmonia oral não se realiza como a musical, no plano dos sentidos, porque palavras não se fundem como sons, antes se baralham, tornam-se incompreensíveis. A realização da harmonia poética efectua-se na inteligência." 23 . As palavras não possuem a capacidade de se fundir como as notas executadas em uma música, por isso a elaboração de um acorde literário se dá de outra maneira, não na junção sonora, mas sim na harmonia realizada por conexões mentais que permanecem inconclusas.

Durante a narrativa, há diversos trechos em que se pode observar a polifonia poética, tal como concebida por Mário de Andrade, ou seja, as frases vibram soltas na narrativa, criando "supostas notas melódicas" que se sobrepõem. É o caso dos trechos destacados abaixo que, no momento em que são lidos, permanecem vibrando na mente do leitor devido à repetição e/ou suspensão do sentido:

[...] ela ia andando - até onde, até onde? Não havia limite, o teclado escondia o infinito. [...] (GERSÃO, 1999, p.30).

[...] - e a levaram - para onde? Para onde? Oh, a música era demasiado misteriosa para não ter medo de se embrenhar nela sozinha. (GERSÃO, 1999, p.31). (grifo nosso)

A repetição proposital de tais trechos causa um efeito sobre o leitor, pois tudo que é repetido chama a atenção para si, causando a ressonância do que está sendo destacado através da repetição. A esta repetição de trechos Mário de Andrade chamou de polifonia poética, que, em outras palavras, nada mais é que os acordes "musicais" do texto, os quais têm por objetivo chamar a atenção do leitor para o elemento melódico, onde se concentra o conteúdo essencial da reflexão. Desse modo, na elaboração dos acordes textuais, por meio da repetição de frases, enfatiza-se o elemento harmônico.

Os trechos destacados parecem fora de contexto gramatical, e por isso, as frases permanecem vibrando na mente do leitor, como se buscassem um complemento, um significado. Em outras palavras, tem-se, nesse trecho, a polifonia poética, na concepção de Mário de Andrade.

\footnotetext{
${ }^{23}$ ANDRADE, Mário. "Prefácio Interessantíssimo" in: Pauliceia Desvairada. São Paulo: Casa Mayença, 1922, p.27.
} 
Para Mário de Andrade, Harmonia, no contexto da literatura, reside no fato de que as repetições acarretam a suspensão do sentido, pois as frases se desgarram da lógica do discurso e ficam interrogando.

Mário de Andrade, no prefácio à Pauliceia Desvairada, definiu as artes temporais como um sistema de construção elaborado na memória do leitor. A decodificação passa, neste caso, a ser auxiliada pela repetição das frases ao longo da narrativa, ou seja, pela harmonia. Veja-se a definição que o autor oferece para as artes do tempo:

[...] A compreensão das artes do tempo nunca é imediata, mas mediata. Na arte do tempo coordenamos actos de memória consecutivos, que assimilamos num todo final. Este todo, resultante de estados de consciência sucessivos, dá a compreensão final, completa da música, poesia, dansa (sic) terminada. (1992, p. 27)

Como afirma Mário de Andrade, a compreensão das artes que se estruturam no tempo necessita de uma repetição; assim, será melhor assimilado o todo da obra. O ato da repetição reforça o ato interpretativo durante a leitura. O leitor não precisa reler o texto, o próprio texto se repete para auxiliá-lo em sua compreensão. Logo, enquanto a linha melódica elabora o enredo, a linha harmônica auxilia o leitor no ato interpretativo.

No trecho a seguir, tem-se o exemplo da construção desses acordes, ou, ainda, de polifonia poética no conceito de Mário de Andrade:

Não lhe disse que tinha medo de afogar no teclado. [...] Não lhe falou de seu medo de improvisar [... ] não lhe disse que antes de tocar estava a ouvir o modo exacto como deveria soar cada nota [...] $\underline{\text { Não }}$ lhe disse estas coisas nem outras [...] (GERSÃO, 1999, p. 49 - grifo nosso)

A repetição da frase "Não lhe disse" e de sua equivalente "Não lhe falou" chama a atenção do leitor para o ato reflexivo de Júlia na linha melódica do texto. Os medos de Júlia estão sendo apresentados ao longo da linha melódica textual: "[...] medo de afogar no teclado.” e “[...] medo de improvisar"; já na linha harmônica a presença dos acordes 
destaca tais reflexões: “[...] Não lhe disse [...] Não lhe falou [...] não lhe disse [...] Não lhe disse [...]", também apresentando o silêncio vivenciado por Júlia num processo de auto-reflexão solitário, acompanhado pelo leitor, que, por sua vez, é guiado pelo narrador onisciente.

Há, contudo, o momento em que a linha harmônica chama a atenção para si mesma. Quando, num exemplo já citado, se ouve, por meio da descrição dos timbres dos sons emitidos pelos instrumentos, uma orquestra executando a "voz" de tio Octávio. Convém lembrar, mais uma vez, o trecho já citado:

[...] Estafermos, diziam os violoncelos. Não pode um homem ter um minuto de sossego em sua casa sem vir um cretino estragar tudo. (Sem vir um cretino estragar tudo, repetia, mais alto, o primeiro violino, numa voz aguda). Vão para o inferno, vão para o inferno, ameaçavam, em coro os contrabaixos. (GERSÃO, 1999, p.08).

A palavra "Estafermos" está associada ao som de violoncelos, som este mais grave que o do primeiro violino, que, por sua vez, é executado na sequência, tocando o trecho "sem vir um cretino estragar tudo. Sem vir um cretino estragar tudo, repetia [...]" cujo som é indicado como agudo "numa voz aguda". Entram em cena os contrabaixos, de som bem grave, que, em coro, executam o trecho "Vão para o inferno, vão para o inferno". Por todo este trecho, a repetição das frases não está destacando a melodia, mas sim a própria elaboração dos acordes, descrevendo o som executado por cada instrumento, ora como grave ora como agudo. Essa operação sonora elaborada no tempo musical e literário será melhor abordada no capítulo sobre o tempo.

A concepção de acorde como repetição de notas que se sobrepõem, vibrando e chamando atenção do leitor para a melodia, de modo que ele elabore na inteligência as relações entre as "notas" que vibram na narrativa, traz à mente, daquele que lê $O s$ Teclados, as diversas repetições existentes no livro, desde frases inteiras até questionamentos e a concepção de objetos que variam durante o enredo.

Bom exemplo disso é a palavra chave, que ora aparece como objeto concreto nos bolsos de Eurico e nas mãos de Tio Octávio, ora aparece como elemento abstrato, comparado a uma clave, para se entender a execução das notas musicais, ou, ainda, como chave para a compreensão do mundo, do universo, através da racionalidade da 
linguagem matemática e das diversas teorias filosóficas sobre a criação do universo, tais como as Leis de Kepler.

A repetição da palavra chave também atua na obra como acorde, chamando a atenção do leitor para as diversas representações deste signo. Abaixo a palavra chave aparece como instrumento que proporciona ao tio Eurico ora sua prisão, ora sua liberdade:

[...] enquanto tio Eurico fugia, tropeçando na passadeira, e desaparecia depressa atrás da porta do quarto de dormir. Devia ter se ouvido nesse instante, o rodar da chave.

Porque a chave do quarto ele não fazia desaparecer nem perdia, traziaa sempre no bolso do casaco ou das calças, outras vezes no pescoço, presa com um cordel ou uma guita. Ou escondia-a, noutras ocasiões, quando ficava mais tenso ou o coração lhe adivinhava algum perigo. Surpreendera-o um dia, concentrado, escavando a terra com as mãos e enterrando a chave num vaso do jardim. [...] (GERSÃO, 1999, p.09$10)$.

A chave era o símbolo da prisão de Eurico, logo ele a escondia ou trazia sempre junto de si, de modo que tio Octávio não pudesse prendê-lo no quarto. Eurico não compreendia a ordem estabelecida, a moral vigente; era o anormal, isto é, aquele que está fora da norma e, por conta disso, representava uma vergonha social pela qual tio Octávio e tia Isaura não desejavam passar. Prender Eurico em seu quarto era uma maneira de apresentar às pessoas a imagem de um casal que deveria ser respeitado, ao invés da imagem de uma família com um parente louco.

Ao mesmo tempo, a chave (instrumento) é comparada à clave (musical). A clave, na partitura, como já foi explicado no capítulo anterior, é a essência para a realização da leitura da partitura. Sem a clave, o intérprete não sabe como deve ler a notação musical na pauta, pois os desenhos (notas, pausas) são os mesmos, mas a significação dependerá da clave. Se a clave for de Sol, por exemplo, os desenhos na pauta referem-se a determinadas notas, já, se a clave for de Fá, os mesmos desenhos indicarão outras notas. Por isso, saber a clave é ter a "chave" para compreender a partitura e poder executar a leitura da mesma e, por conseguinte, tocar. Nesse sentido, a palavra "chave" também pode assumir o sentido de "chave de leitura".

Mais adiante, a palavra "chave" reaparece referindo-se às explicações dadas pelo professor de matemática sobre as teorias filosóficas da criação do universo: "Deixava- 
lhe na mão uma chave, um fórmula que abria o universo, e ia-se embora, como se nada fosse. [...]" (GERSÃO, 1999, p.73-74). Rogério Souto explica a Júlia a criação do universo, relatando o mito de Er, de Platão, já abordado no primeiro capítulo, assim como as leis de Kepler, em especial a segunda lei, que será abordada no capítulo final. Após o relato do mito e das leis, feito pelo professor, Júlia, de maneira racional e não mais intuitiva, pensa sobre a criação do universo. Na verdade, como ainda não compreende tudo que lhe foi exposto, ela tem a "sensação" de ter em mãos a "chave filosófica" para a decifração do mundo; no entanto, ainda não consegue estabelecer todas as conexões entre a teoria e a prática.

Portanto, ao repetir palavra "chave" na narrativa, com distintas funções e efeitos de sentido, a autora cria o efeito estético do acorde na literatura. Na verdade, ela produziu o que Mário de Andrade chamou de polifonia poética, cuja decifração só se dará na inteligência (do leitor) através das correlações entre os vários significados do signo linguístico "chave".

Seguindo ainda a linha harmônica, também se destaca a repetição da palavra "mão" e outras palavras diretamente relacionadas a ela, como "dedos" ou "punho". A palavra "mão" caracteriza, de forma metonímica, a comunicação, o exercício da escrita, o toque musical e humano e a repreensão, dentre outras coisas.

Estão transcritos abaixo os trechos que apresentam a palavra mão e suas referências, elaborando, ao longo da narrativa, os acordes e chamando constantemente a atenção do leitor para a imagem das mãos. No próprio romance, elas aparecem, primeiro, como repressoras:

[...] batia com o punho na mesa de camilha como se tentasse afugentar, pelo barulho, o intruso que entretanto retrocedera [...] (p.07)

Não contava com o barulho terrível das palmas, como se estivessem a bombardear a sala. (GERSÃO, 1999, p. 27- grifo nosso)

Mas é o fim de um artista, se não baterem palmas, disse no dia seguinte o tio Octávio. Ai dele, se não baterem. (GERSÃO, 1999, p.27 - grifo nosso)

Abaixo, as mãos como projeções de comportamento, primeiramente de tio Octávio: 
[...] e pouco e pouco parecia adormecer, com as mãos cruzadas em cima da barriga.

Beethoven, dizia no fim abrindo os olhos e levantando o dedo indicador, quando finalmente a música parava. [...] (p.08)

Posteriormente, o comportamento de Júlia e Ireninha que se assemelham pela vergonha; a primeira diante dos tios ao ser descoberta como potencial musicista, e a segunda, com vergonha diante do público:

[...] enterrando as mãos nos bolsos do vestido, disposta a esquecer o incidente. (GERSÃO, 1999, p.24- grifo nosso)

Ela [Ireninha] torcia a ponta do vestido entre os dedos, encostada ao muro, fingindo não ouvir. (GERSÃO, 1999, p.26 - grifo nosso).

O comportamento da angústia do pai de Ireninha antes de sua audição, ou o habitual comportamento de Palrinha ao ouvir Júlia ao piano:

O pai andava de um lado para o outro, de mãos atrás das costas. (GERSÃO, 1999, p.26 - grifo nosso).

Habitualmente ele [Palrinha] passeava entre a janela e a porta, de mãos atrás das costas, enquanto Júlia tocava. (GERSÃO, 1999, p.46 - grifo nosso)

As mãos, vistas agora como instrumento de criação artística, nas duas primeiras citações, a interpretação da musicista ao tocar; em seguida, a elaboração do texto literário a partir do uso do teclado do computador:

[...] os dedos todos iguais, atacando as teclas muito perto, no início não obedecendo, até que finalmente se soltavam e a música se ouvia. (p.13)

[...] e os dedos mudavam-se passando o polegar debaixo do maior, curvando em arco. (GERSÃO, 1999, p.24-25- grifo nosso)

O teclado permitia maior velocidade do que a caneta, uma vez que ambas as mãos participavam e se podiam usar todos os dedos. [...] 
reduzia-se de algum modo a distância entre o cérebro e a mão [...] (GERSÃO, 1999, p.53- grifo nosso).

Era ilusório pensar se escrevia com as mãos, ou se tocava com as mãos: também o teclado do piano era uma transparência. (GERSÃO, 1999, p.54- grifo nosso).

[...] Parecia fascinado pelas mãos: Havia pessoas que conduziam máquinas, transportavam pedras, tratavam doentes, assentavam ladrilhos - não seriam essas mãos mais úteis? (GERSÃO, 1999, p.55grifo nosso).

As mãos, como meio de comunicação entre Júlia e Eurico:

[...] Outras vezes batia com os pés e as mãos e dava estalos com os dedos, como castanholas. [...] ele pegava-lhe nas mãos, voltava-as com as palmas, para cima, media o comprimento dos dedos, comparando-os com os dele, batia-lhe levemente com a colher nas unhas e sorria. (GERSÃO, 1999, p. 20 - grifo nosso).

As mãos, como metonímia da dor, da angústia da criação artística no mundo contemporâneo:

[...] aliás nem podia tocar muito porque tinha os dedos cheios de artroses, tinham começado a deformar-se anos atrás, até chegar ao ponto em que agora estavam. O polegar fora o primeiro, a certa altura dera conta de que não alcançava a oitava. (GERSÃO, 1999, p.47 grifo nosso)

[...] E lhe ralhava quando ela tocava demais e abria os pulsos e não dava conta - a não ser depois, quando os movimentos se tornavam dolorosos e tinham de pôr uma ligadura em volta e passar vários dias sem tocar. [...] Palrinha percorria a pauta com os dedos tortos (o polegar fora o primeiro. A certa altura dera conta de que não alcançara a oitava). (GERSÃO, 1999, p. 67 -68, - grifo nosso)

[...] Deu conta de que ele pousara a mão cautelosamente, como se tentasse protegê-la. Ou proteger-se, porque devia, provavelmente, sentir dor [...] (GERSÃO, 1999, p.86 - grifo nosso)

A mão, como metonímia da liberdade: 
O teclado permitia maior velocidade do que a caneta, uma vez que ambas as mãos participavam e se podiam usar todos os dedos. [...] reduzia-se de algum modo a distância entre o cérebro e a mão [...] (GERSÃO, 1999, p.53- grifo nosso)

[...] A pata imensamente presa ao chão. (Enquanto a mão voava). (GERSÃO, 1999, p.69- grifo nosso)

As mãos, como espelho, refletindo, na pianista, Júlia, a escritora (Helena Estevão) e o louco (tio Eurico):

[...] ele [Eurico] pegava-lhe nas mãos, voltava-as com as palmas, para cima, media o comprimento dos dedos, comparando-os com os dele [...] (GERSÃO, 1999, p.20 - grifo nosso)

[...] Tocara no piano de cauda, [...] e era polido e brilhante e onde as mãos se refletiam como em espelhos. [...] Também ela tinha consciência de que o teclado não existia, de que não se tocava com as mãos - em alguns pontos, sim, em alguns pontos a visão de ambas coincidia - como se por um momento, no lugar das suas, fossem as mãos da outra que via refletidas. (GERSÃO, 1999, p.69-70 - grifo nosso)

As mãos, como metonímia dos olhos no ato da leitura:

Tudo que podia fazer era ler com ele uma partitura. Agarrou-lhe a mão e começou devagar a percorrer a pauta. Viu que ele tinha magoado o indicador direito: junto da base, debaixo da unha, havia um coágulo de sangue. (GERSÃ̃, 1999, p.81- grifo nosso)

[...] Deu conta de que ele pousara a mão cautelosamente, como se tentasse protegê-la. Ou proteger-se, porque devia, provavelmente, sentir dor [...] (mão, pensou de repente. Um momento de triunfo sobre o teclado[...]) (GERSÃO, 1999, p.86 - grifo nosso)

Todos os trechos acima simbolizam, na narrativa, a construção dos acordes, ou da polifonia poética, chamando a atenção do leitor para a multiplicidade de significados que a palavra "mão" e suas referências (punho, pulso, dedos, palmas) adquirem na história. 
Assim, por meio do recurso da repetição, a autora faz com que o leitor reflita sobre os acordes do texto, cuja vibração (repetição) permanece durante a leitura, despertando o leitor para uma leitura crítica da obra.

\subsection{Refrão, ritornelo ou estribilho}

Um recurso habitual na narrativa d'Os Teclados é a técnica de refrão, também chamado de ritornelo ou estribilho. Segundo Mário de Andrade em seu Dicionário Musical Brasileiro (1999), refrão é um: "Trecho que se repete periodicamente, geralmente uma frase, um dístico ou uma quadra. O mesmo que ritornelo ou estribilho." (p.433).

$\mathrm{Na}$ Literatura, a repetição exata de frases e expressões, ao longo da narrativa, chama a atenção do leitor para si. Desse modo, a própria narrativa conduz a atenção do leitor para os trechos que se repetem. Portanto, pode-se inferir que o recurso do refrão completa a técnica de polifonia poética destacando trechos que merecem mais vigilância do leitor.

Vale ressaltar que o refrão e a polifonia poética apresentam nítidas diferenças, pois o refrão repete, literalmente, tópicos frasais ao longo da narrativa; enquanto a polifonia poética "reinventa" a frase, repetindo seu significado, mas não a mesma estrutura sintática, logo, há uma aparente repetição frasal. Apesar dessa diferença estrutural quanto à repetição de trechos importantes para o enredo, ambas as técnicas auxiliam o leitor em seu ato interpretativo, destacando elementos que mereçam a sua atenção.

Nos dois fragmentos abaixo, percebe-se a repetição dos trechos: "Se as pessoas formassem uma comunidade" e "tudo era fragmentário" onde o leitor poderá interpretar como o uso da técnica de refrão:

[...] Algumas pessoas eram feitas para desvendar enigmas, passariam a vida a tentar. O que seria mais suportável se pudesse fazê-lo em nome também dos outros, porque então não estariam sós, a tarefa seria colectiva. Se as pessoas formassem uma comunidade. [...] Talvez 
não, tudo no mundo era fragmentário, as pessoas não formavam comunidades e só havia valores de troca. [...] (GERSÃO, 1999, p.56).

\section{[...] As pessoas não formavam comunidades, tudo era}

fragmentário e no fundo indiferente, porque todos os valores eram de troca. O mundo era um monte de estilhaços, era isso o que a mulher tinha dito? (GERSÃO, 1999, p.59-60).

Ao repetir os trechos já destacados, o narrador acaba conduzindo o leitor a pensar sobre as comunidades interpretativas ("Se as pessoas formassem uma comunidade"), principalmente, a falta delas nessa sociedade contemporânea, ou ainda, a ausência de discussões produtivas, em outras palavras, as poucas comunidades existentes mantêm discussões incipientes.

Além desse trecho que se repete várias vezes, tem-se a presença da técnica de refrão quando Júlia cita o ato de ouvir. A tentativa de definir o ato de ouvir aparece sempre precedida pela expressão: “ ouvir era...”. Observa-se esse refrão nos trechos a seguir:

Ouvir era um segredo. [...] (GERSÃO, 1999, p.13)

Ouvir era uma absoluta atenção às coisas. [...] (GERSÃO, 1999, p.14)

Mas ouvir não era separado de ver, sentir ou entender. [...] (GERSÃO, 1999, p.14)

Ouvir era deixar o mundo entrar em si. [...] (GERSÃO, 1999, p.15)

[...] Ouvir era talvez isso: tomar parte entre a medida e o caos. (GERSÃO, 1999, p.16).

Ao repetir a expressão já citada, chama-se atenção para a descrição do ato de ouvir que, para Júlia, é um segredo a ser descoberto. Nesse sentido, o leitor deve buscar compreender qual o segredo do ato de ouvir, uma vez que ouvir, nessa narrativa, é sinônimo de ler. Para complementar o uso das técnicas de refrão e polifonia poética, segue a análise da técnica de retardamento na narrativa d'Os Teclados; vale destacar que todas essas técnicas musicais, apresentam-se no enredo, para enfatizar trechos que 
devam ter uma atenção especial do leitor, ou seja, é a Música auxiliando a Literatura a conduzir seu leitor no ato interpretativo.

\subsection{A técnica de retardamento}

Outro recurso musical também ligado à linha harmônica é a técnica de retardamento, amplamente utilizada por Teolinda em Os teclados. Ela faz uso dessa técnica pela reiteração de uma pergunta ou pelo adiamento da explicação de algo já exposto. Tal recurso põe o leitor em contato com as intuições da protagonista, fazendo com que ele reflita junto com ela, pois o retardamento da resposta e a repetição da pergunta inevitavelmente conduzem o leitor à melodia da partitura literária entoada, reforçando-lhe o tom reflexivo. Segue um exemplo de retardamento na narrativa: "Por que razão o tempo encurtara e tudo se convertera em mercado? Que queria ela dizer, finalmente? Havia ou não um sentido no mundo?" (p. 58) Essas questões ficam sem resposta, vibrando na consciência do leitor.

O retardamento apresentado acima por meio da indagação sobre o mercado busca convencer o leitor sobre a existência de uma verdade que ainda não foi, de fato,

encontrada. É uma hipótese que ainda não se concretizou enquanto afirmação. Esta estrutura retórica e musical gera, no leitor, um fluxo reflexivo sobre o que está sendo apresentado. Este trecho, especificamente, é marcado por outra pergunta que se infere do subtexto: há um sentido para as coisas no mundo ou tudo havia se transformado em mercado, inclusive a arte? Aqui, a estrutura retórica e musical baliza as reflexões de quem está lendo; o fato de a resposta não ser dada faz com que o próprio leitor elabore a sua resposta ou perceba que a resposta para tal pergunta ainda não foi encontrada.

Segue o trecho que exemplifica outra incidência da técnica de retardamento utilizada por Teolinda:

[...] Porque então não estaríamos sós, a tarefa seria colectiva. Se as pessoas formassem uma comunidade. [...] Talvez não, tudo no mundo era fragmentário, as pessoas não formavam comunidades e só havia valores de troca. [...] As pessoas não formavam comunidade, tudo era fragmentário e no fundo indiferente, porque todos os valores eram de 
troca. O mundo era um monte de estilhaços, era isso que a mulher tinha dito? (GERSÃO, 1999, p.56-58).

A técnica de retardamento aparece em Os Teclados auxiliando o leitor real a realizar a interpretação do texto. Na narrativa, a personagem Helena Estevão expõe seu ideal de leitor: "Ela gostava de pensar que o leitor era como o escritor, de certa maneira a sua outra face, disse a mulher. [...] Reinventava o livro, como o intérprete tocando a partitura”. (GERSÃO, 1999, p.55). E pode-se notar, por meio da concepção verbalizada, que o exercício da leitura do texto literário é comparado ao ato realizado pelo intérprete, estabelecida por uma relação de entrega e descoberta, onde o leitor/intérprete buscaria construir a significação do texto/partitura.

Em um texto literário, o leitor, segundo Iser (1999), tem uma boa compreensão do texto desde que este formule um sentido para o leitor. No ato da leitura, a constituição do sentido de um texto envolve o entendimento dos aspectos formuladores do texto, bem como a formulação do não-formulado, ou seja, construir significação a partir das elipses, metáforas, metonímias e correlações históricas, filosóficas, literárias existentes no texto. Desse modo, o jogo realizado pelo leitor no ato da leitura, no caso d'Os Teclados, a partir das técnicas e dos elementos musicais presentes no texto, parece auxiliar o leitor a ordenar-se a si mesmo como intérprete por meio da entrega ao jogo do texto.

Nesse sentido, a técnica de retardamento ajuda o leitor a compreender criticamente os elementos artísticos que compõem o texto. Realizando uma boa interpretação desses elementos, o leitor executa bem a sua "partitura", de forma criativa e interacional. No próximo capítulo, a construção do jogo do texto e seus efeitos estéticos serão detalhadamente explicados. 


\section{CAPÍTULO V}

\section{A ESCUTA DA PARTITURA LITERÁRIA} D'OS TECLADOS 


\section{CAPÍTULO V}

\section{A ESCUTA DA PARTITURA LITERÁRIA}

\section{D'OS TECLADOS}

Este capítulo tem por objetivo compreender o ideal de leitor traduzido nas palavras da personagem Helena Estevão, procurando verificar como esse ideal auxilia na formação do "eu" de Júlia, além de provocar reflexões críticas nos leitores da obra sobre os seus efeitos estéticos.

O foco do capítulo está na entrevista concedida por uma escritora até então desconhecida, e que Júlia lê a princípio superficialmente, enquanto espera sua vez de ser atendida pelo dentista. Na verdade, o interesse de Júlia só é de fato despertado quando ela lê, no texto, a palavra teclado. No começo, ela acredita que a entrevistada era uma musicista; depois, decepcionada, descobre se tratar de uma escritora. Entretanto, apesar disso, prossegue a leitura, pois percebe semelhanças entre a relação da escritora com seu teclado do computador e a que ela mantinha com o teclado do piano, ou ainda, entre suas angústias ao tocar e as angústias da escritora ao escrever. É o que se pode ver no excerto abaixo:

A mulher estava ligada ao teclado, dizia, ele fazia parte de sua vida. Mas em último caso o teclado não existia, era uma pura transparência. Ela procurava alguma coisa que não era da ordem das palavras, embora só pudesse transmiti-la em palavras, algo talvez comparável à música, embora não equivalente. Ondas de energia, que se organizavam em uma determinada estrutura - sim, talvez se pudessem pôr as coisas nesses termos, não sabia ao certo. Aceitava entregar-se aquele trabalho que não era verdadeiramente explicável e não se podia controlar. Era uma tarefa desmedida, mas também perigosa, porque se trabalhava sem rede. (GERSÃO, 1999, p. 52) 
A própria escritora Helena Estevão estabelece, na entrevista, a relação entre Literatura e Música, dizendo que: [...] os livros aconteciam no tempo. Como a música. Os romances sobretudo. Eram, como a música, uma forma de medir e de organizar o tempo.” (GERSÃO, 1999, p.54) Júlia se depara, então, com uma comparação entre Literatura e Música, ambas artes temporais, cujo intuito é "medir e organizar o tempo".

Essa sucessão de relações entre as duas artes leva a jovem a refletir sobre o momento de criação artística, no caso da experiência literária e no da interpretação (ou composição) musical. Ela reconhece os elementos comuns entre as duas artes, como, por exemplo, o elemento temporal, evidente no fato de ambas terem frases ligadas umas às outras, formando uma espécie de tecido. No caso da Música, seu tecido é expresso em uma partitura; já na Literatura é expresso no texto.

Além da semelhança entre esses elementos, também ocorre uma identificação entre as angústias da protagonista e as da escritora quanto às expectativas dos respectivos públicos. A esse respeito, a entrevistada expõe seu ideal de público leitor:

Ela gostaria de pensar que o leitor era como o escritor, de certa maneira a sua outra face, disse a mulher: Aceitava os mesmos riscos, passava as mesmas noites em claro, tropeçava nos mesmos escolhos, sonhava os mesmos sonhos. Para depois reagir contra eles. Reinventava o livro, como o intérprete tocando a partitura. Por vezes numa direção muito diferente. Era verdade que ela gostava - ou gostaria - de pensar isso, repetiu depois de um silêncio. Mas num mundo em que os valores eram de troca, tudo se tornara de certo modo indiferente. O leitor, como o escritor, tornara-se uma personagem rara. (GERSÃO, 1999, p. 55).

Através dos pensamentos da protagonista sobre esse "leitor idealizado" pela escritora Helena, o leitor empírico d'Os Teclados depara-se com o desejo de que o leitor fosse "[...] como o escritor, de certa maneira a sua outra face". A partir desta declaração, ele, leitor empírico, acaba sendo levado a refletir sobre o papel dele mesmo enquanto receptor da obra em questão. 
O ideal apresentado na narrativa traduz o desejo de um leitor que interprete a obra literária interagindo com ela, entrando no jogo do texto, compreendendo as referências textuais articuladas pela narrativa. Logo, o leitor idealizado deverá ter conhecimento de outras obras literárias, mitos, filósofos e, no caso de Os Teclados, ainda conhecimentos musicais. A partir desse universo intelectual e das experiências vivenciadas por ele, o ato interpretativo poderá ocorrer.

Quando, na leitura que, juntamente com Júlia, faz daquela entrevista a Helena Estevão, o receptor se defronta com a descrição de um leitor ideal e com o questionamento da morte do leitor: "Poderia falar-se, pelo menos a prazo, da morte do leitor?", (GERSÃO, 1999, p.54), pode-se intuir que Teolinda Gersão, de certo modo, está levando seu leitor a refletir sobre si mesmo, buscando, ainda, fazê-lo perceber a dinâmica do ato de leitura da obra, ou seja, os efeitos estéticos vivenciados ao longo desse processo.

Tais efeitos estéticos, como este estudo tem procurado mostrar, estão ligados ao tempo e à música, pois a narração é, desde o início, percorrida por elementos musicais, que estão incrustados no tecido do texto. Tais elementos, sutilmente articulados, têm o poder de enredar o leitor ou, dito de outro modo, enfeitiçá-lo pela narrativa, como se esta fosse o canto das sereias.

Antes de examinar os efeitos estéticos, cabe, neste momento, introduzir a abordagem que sustenta esta análise, ou seja, a da Estética da Recepção, de Wolfgang Iser, em $O$ ato da leitura - Teoria do Efeito Estético (v. 2), (1999):

[...] O leitor se move constantemente no texto, presenciando-o somente em fases; dados dos textos estão presentes em cada uma delas, mas ao mesmo tempo parecem ser inadequados. Pois os dados textuais são sempre mais do que o leitor é capaz de presenciar neles no momento da leitura. Em consequência, o objeto do texto não é idêntico a nenhum de seus modos de realização no fluxo temporal da leitura, razão pela qual sua totalidade necessita de sínteses para poder se concretizar. Graças a essas sínteses, o texto se traduz para a consciência do leitor [...]. (1999, p.13)

Segundo Iser, o leitor, enquanto lê, tem dificuldade em entender todos os elementos do texto. Para que esta compreensão se realize, é necessário que ele faça a síntese da totalidade do texto ou, ao menos, dos seus elementos mais importantes. 
$\mathrm{Na}$ verdade, a técnica de retardamento, em que a repetição de uma pergunta induz o leitor a refletir sobre ela, constitui, de certo modo, um meio de o narrador fazer para o leitor uma síntese dos elementos a que ele deve prestar mais atenção. Logo, tratase de um modo de conduzir o olhar do leitor para que este realize o ato interpretativo, segundo uma expectativa exposta pelo autor implícito. No fragmento a seguir, pode-se perceber a técnica de retardamento:

[...] porque então não estaríamos sós, a tarefa seria colectiva. Se as pessoas formassem uma comunidade. Talvez não, tudo no mundo era fragmentário, as pessoas não formavam comunidades e só havia valores de troca. [...] As pessoas não formavam comunidade, tudo era fragmentário e no fundo indiferente, porque todos os valores eram de troca. O mundo era um monte de estilhaços, era isso que a mulher tinha dito? (GERSÃO, 1999, p.56-58).

Na narrativa aparece uma afirmação/resposta ("Porque então não estaríamos sós, a tarefa seria colectiva. Se as pessoas formassem uma comunidade”.). Em seguida ela é questionada e negada ("Talvez não, tudo no mundo era fragmentário, as pessoas não formavam comunidades e só havia valores de troca.”), e a negação é repetida (“As pessoas não formavam comunidade, tudo era fragmentário e no fundo indiferente, porque todos os valores eram de troca".) e, por fim, tudo que foi exposto é novamente questionado (“O mundo era um monte de estilhaços, era isso que a mulher tinha dito?”), levando o leitor a pensar criticamente a partir da reiteração das frases na narrativa e do retardamento de uma resposta efetiva. Como se vê, a técnica de retardamento conduz o leitor a uma reflexão a partir do adiamento da resposta, pois ele acaba pensando na resposta e na pergunta expostas no texto, ou melhor, pensa a partir da contradição ali apresentada.

Além da técnica de retardamento, aparece na narrativa, a chamada polifonia poética, também conhecida por acorde, já vista no capítulo anterior. Ao repetir palavras ou frases na narrativa, o narrador acaba chamando a atenção do leitor para essas frases onde estão elementos-chave para a compreensão do texto ou que levarão à compreensão de determinados aspectos. Como exemplo disso, vejam-se os fragmentos a seguir: 
Se as pessoas formassem uma comunidade. (GERSÃO, 1999, p.56).

[...] Tudo no mundo era fragmentário, as pessoas não formavam comunidades e só havia valores de troca. (GERSÃO, 1999, p.56)

[...] As pessoas não formavam comunidades, tudo era fragmentário e no fundo indiferente, porque todos os valores eram de troca. (GERSÃO, 1999, p.57).

Conforme se pode ler, a questão das comunidades, dos valores de troca e da fragmentação está repetida. As frases ficam soltas na narrativa, como se vibrassem, chamando a atenção do leitor para elas através de sua repetição e de um sentido que permanece, em princípio, enigmático. Essa técnica de repetição e suspensão de sentido corresponde ao acorde ou, no conceito de Mário de Andrade, à polifonia poética. Toda arte temporal (Literatura e Música), para ser melhor compreendida, necessita das sínteses consecutivas de seu conteúdo, pois, desse modo, o leitor é capaz de entender o conjunto da narrativa. No entanto, em Os Teclados, a própria narrativa já se repete através dos recursos da polifonia poética, do refrão ou ainda da técnica de retardamento, assim o leitor já realiza a síntese sobre as reflexões críticas do texto durante o próprio ato da leitura.

A essas lacunas Iser chamou de "vazios textuais". Os vazios textuais são vistos como conexão potencial para a compreensão do texto literário. Todo texto, segundo ele, possuiria "falhas", "lacunas" em sua estrutura, que deveriam ser preenchidas pelos conhecimentos do leitor. Geralmente, tais "falhas ou lacunas" aparecem logo após metáforas ou recursos linguísticos presentes no texto, tais como as técnicas de retardamento, aqui já vistas ou a polifonia poética. Cabe ao leitor adentrar esses vazios textuais, pensar o texto formulado afastando-se do uso pragmático da fala, forçando-se a reformular o texto para poder incorporá-lo e interpretá-lo. Por conseguinte, os vazios textuais são fundamentais para que o leitor abandone suas expectativas habituais e adentre as lacunas existentes no texto, reconstruindo-o a partir de uma reflexão crítica sobre esse mesmo texto. Obviamente há leitores que adentram os vazios textuais, mas não conseguem se aprofundar nas reflexões críticas e se perdem nesses vazios; o 
resultado disso é um processo de "falha" no ato interpretativo e, portanto, o leitor não compreende satisfatoriamente o tex to lido.

Logo, adentrar os vazios textuais com atenção e compreender o texto a partir dessas lacunas é essencial para a boa compreensão dos elementos que compõem o texto literário, segundo Iser e Compagnon ${ }^{24}$ Os leitores que não conseguem fazer adequadamente este percurso por entre os vazios textuais e sair deles reformulando o texto, acabam por ser tratados como "leitores rasos", sem compreensão crítica do texto.

No entanto, esse percurso poderia ser auxiliado pelo leitor implícito e pelo autor implícito do texto. Em Os Teclados, o leitor perceberá, ao longo da leitura, que Helena Estevão é a personagem em que se projeta o autor implícito, inclusive descrevendo seu ideal de leitor; enquanto Júlia, ao ler as partituras, tem em si a projeção do ideal de leitor, ou o chamado leitor implícito. Portanto, Júlia, tocando e ouvindo, assemelha-se ao receptor do texto literário.

No entanto, quando o narrador, ao longo da narrativa, enfatiza os momentos em que o leitor deve se deter, este acaba sendo muito auxiliado no ato interpretativo, pois o narrador destaca, de forma consciente, a correlação dos signos linguísticos, bem como as principais ideias, sinalizando uma espécie de síntese para o leitor. Assim, a técnica de retardamento, em que as perguntas são repetidas várias vezes ao longo da narrativa, auxilia o leitor na elaboração de sua reflexão sobre as possibilidades de respostas, e, ao mesmo tempo, o narrador cria um efeito estético no leitor e o ajuda a elaborar a coerência do texto, ou seja, a Gestalt.

A teoria da Gestalt, segundo Iser, apresentará, parcialmente, os motivos pelos quais os leitores, ao lerem uma obra, muitas vezes se perdem dentro da leitura. Segundo ela, o ser humano, comprovadamente, ao ler os traçados tipográficos de um texto, consegue enxergar no máximo dois pontos por vez; logo, não lê o traçado de cada letra individualmente. Se cada letra não pode ser lida individualmente, o mesmo ocorrerá com a relação de sentido entre os signos linguísticos. Assim, o leitor fará, primeiro, a interpretação de uma série de signos linguísticos, para depois relacioná-la com outra série de signos. Essa correlação de signos é a Gestalt.

Esta tentativa do leitor de correlacionar os signos linguísticos recebe o nome de coerência. Quando ele não consegue compreender as correlações da Gestalt, passa

\footnotetext{
${ }^{24}$ ISER, Wolfgang. O ato da leitura - Uma teoria do efeito estético. V. 02. São Paulo: Editora 34. 1999. COMPAGNON, Antoine. O Demônio da Teoria - Literatura e senso comum. Belo Horizonte: UFMG, 2001.
} 
também a não compreender a coerência do texto. E é exatamente nesse momento que ocorrerá uma espécie de "falha" no processo de leitura, ou seja, o leitor passará a não entender os elementos que compõem o texto (tais como metáforas, referências históricas, filosóficas ou mitológicas) e, portanto, a compreensão da totalidade do texto fica prejudicada.

De fato, o narrador, em alguns momentos, determina o fluxo temporal da leitura, utilizando outros recursos musicais. Há instantes, por exemplo, em que a leitura parece "truncada" devido à presença de palavras com consoantes oclusivas e fricativas, como no trecho a seguir, já aqui diversas vezes citado:

[...] Estafermos, diziam os violoncelos. Não pode um homem ter um minuto de sossego em sua casa sem vir um cretino estragar tudo. (Sem vir um cretino estragar tudo, repetia, mais alto, o primeiro violino, numa voz aguda). Vão para o inferno, vão para o inferno, ameaçavam, em coro os contrabaixos. (GERSÃO, 1999, p.08).

A repetição da frase "Sem vir um cretino estragar tudo" e "Vão para o inferno" não traz fluidez ao texto devido aos fonemas $/ v /, \mid t /, / p /$, $/ f /$, aos grupos consonantais (/cr/; /tr/ e à vibrante múltipla /R/), o que acarreta uma desaceleração de leitura em função da dificuldade na pronúncia desses fonemas. Isto é, o leitor, obrigado pela narrativa, "quebra" seu fluxo de leitura e é induzido a uma leitura mais lenta e meditativa, semelhante a um andante na música, ou seja, segundo Piva (1990), "um movimento lento e meditativo, que pode, inclusive, desenvolver uma lamentação sonhadora". (p.69)

Já no trecho em que Júlia entra em contato com o ato de ouvir (a natureza), a presença de consoantes nasais e sibilantes traz fluidez à leitura, conotando uma possível relação harmoniosa entre ela e o universo:

Então ouvia a chuva. Ouvir era uma absoluta atenção às coisas. Tudo ficava suspenso, no vazio. E depois o som acontecia: a chuva, o vento, o mar. O vento nas folhas, o caminho de terra, nos telhados, na chuva. Agora ela ouvia a chuva, as formas fugidias da água (a música, não a da chuva, a música em si mesma, era líquida ou aérea? Líquida, supunha. Sobretudo líquida, diria). (GERSÃO, 1999, p.14). 
A presença dos fonemas $/ \mathrm{s} /, \mathrm{n} / \mathrm{e} / \mathrm{m} /$, bem como o uso de vírgulas ("a chuva, o vento, o mar".) desencadeiam uma leitura com mais fluidez, como se estivesse sendo acelerada, gradativamente, mas de maneira leve. Este artifício causa, na narrativa, efeito semelhante ao que, na música, é causado por um alegro, ou seja, na música, indicação de um tempo rápido, alegre, (ANDRADE,' 1999, p. 16).

Em síntese, no decorrer da narrativa, percebe-se, em diversos trechos, uma diferença no tempo de fruição da leitura, conforme a pontuação ou a ausência desta, ou ainda com a presença repetitiva de determinadas consoantes, como foi apresentado, o que pode acelerar o tempo de leitura (como no trecho: "não não não não não!") ou desacelerar, como se viu no trecho acima.

Todos esses recursos musicais causam no leitor um efeito estético, ou seja, ele se vê conduzido a prestar atenção nas partes que se repetem e, posteriormente, a pensar criticamente sobre certos questionamentos apresentados na narrativa, pois a resposta é retardada e o fluxo de tempo de leitura, modificado ao longo da narrativa, de modo a gerar o ato reflexivo. Assim, o leitor obedece ao "comando" do narrador, como se este fosse um regente.

Desse modo, segundo Compagnon (2001):

O objeto literário não é nem o texto objetivo nem a experiência subjetiva, mas o esquema virtual (uma espécie de programa ou de partitura) feito de lacunas, de buracos ou de indeterminações. Em outros termos o texto instrui e o leitor constrói. [...]

Em Iser, a noção principal decorrente dessas premissas é a de leitor implícito, calcada na de autor implícito, que fora introduzida pelo crítico americano Wayne Booth. [...] Booth defendia a tese segundo a qual um autor nunca se retirava totalmente de sua obra, mas deixava nela sempre um substituto que a controlava em sua ausência: o autor implícito. (p. 150).

Compagnon apresenta a tese de que o texto literário pode ser comparado a uma partitura, no sentido de ambos, texto e partitura, terem lacunas que serão preenchidas, respectivamente, pelo leitor e pelo intérprete musical. Essa mesma comparação entre partitura e texto também ocorre em Os Teclados, como no trecho a seguir: "Ela sentava- 
se ao seu lado, com a ligadura no pulso, e liam as partituras como se fossem livros." (GERSÃO, 1999, p.68).

Quando o leitor d'Os Teclados inicia a leitura do livro, está acompanhando a trajetória de uma garotinha que mora com os tios e pensa sobre os acontecimentos à sua volta, narrando também sua relação com a música. Durante as reflexões de Júlia sobre sua casa e sobre a música, o leitor vai percebendo que ela está se constituindo como sujeito/leitor a partir dos valores éticos/estéticos que apreende, a princípio no ambiente familiar. Dentre tais reflexões, duas se destacam: o tempo e o ato de ouvir.

Essas reflexões se destacam porque auxiliarão na explicação sobre o ideal de leitor veiculado pelas palavras de Helena Estevão. O tempo, tantas vezes mencionado na narrativa, será o tema central do próximo capítulo. Brevemente, o tempo relacionar-seá, na interpretação que melhor convém a esta análise neste momento, com o ato de ouvir e com o comportamento das pessoas diante da vida.

Ouvir é um ato de profunda atenção às coisas do mundo. E para que esse ato seja pleno, a pessoa deve despender, nesta audição, o tempo necessário para a compreensão daquilo que é ouvido.

Quando Júlia apenas olha a partitura e a ouve, na verdade, está lendo cada nota, silenciosamente, e estas se harmonizam dentro dela formando uma música interior, só ouvida por ela, a intérprete. Quando lê em silêncio, o leitor também elabora as relações textuais em seu interior, ou seja, em sua mente, como se fosse capaz de ouvir a "voz do texto" - isto é, o leitor também é um intérprete dos elementos textuais, assim como o intérprete musical. Logo, em Os Teclados, Júlia metaforiza o leitor ideal imaginado por Helena. Esta, por sua vez, apresenta-se como provável projeção do autor implícito, conduzindo o leitor real na sua interpretação do texto.

Quando o leitor examina e reflete sobre o ideal de leitor explicitado na entrevista de Helena, ele pode perceber semelhanças entre as ações daquele leitor ideal, as ações realizadas por Júlia quando ela lê as partituras silenciosamente e as suas (do leitor), no decorrer da sua leitura. No trecho a seguir, vê-se o ideal de leitor apresentado por Helena:

Ela gostaria de pensar que o leitor era como o escritor, de certa maneira a sua outra face, disse a mulher: Aceitava os mesmos riscos, passava as mesmas noites em claro, tropeçava nos mesmos escolhos, sonhava os mesmos sonhos. Para depois reagir contra eles. Reinventava o livro, como o intérprete tocando a partitura. Por vezes 
numa direção muito diferente. Era verdade que ela gostava - ou gostaria - de pensar isso, repetiu depois de um silêncio, Mas num mundo em que os valores eram de troca, tudo se tornara de certo modo indiferente. $\mathrm{O}$ leitor, como o escritor, tornara-se uma personagem rara. (GERSÃO, 1999, p. 55).

O ideal de leitor descrito por Helena equipara-se ao imaginado por Iser, isto é, trata-se do leitor que adentrará os vazios textuais e reformulará o texto a partir de elementos e "enigmas" do próprio texto, percebendo, assim, sua estrutura interna, como se vê no trecho: "Ela gostaria de pensar que o leitor era como o escritor, de certa maneira a sua outra face". O leitor complementaria o escritor, na medida em que ele constrói o texto, também, no ato da leitura. Ou ainda no trecho "Aceitava os mesmos riscos, passava as mesmas noites em claro, tropeçava nos mesmos escolhos, sonhava os mesmos sonhos.", em que se pode perceber o leitor idealizado como aquele envolvido com o texto, passando pelas mesmas angústias do autor ao realizar sua obra.

A esse movimento de controle do leitor empírico pelo leitor implícito, Iser chamou "jogo do texto". Neste jogo, cada um tem seu papel bem determinado, e o espaço do texto é o local em que se instaura tal jogo. Ou nas palavras de ISER (in LIMA, Luiz Costa. A literatura e o leitor - textos da Estética da Recepção):

O jogo do texto, portanto, é uma performance para um suposto auditório e, como tal, não é idêntico a um jogo que se encena para o leitor, a quem é dado um papel, que o habilita a realizar o cenário apresentado.

O jogo encenado do texto não se desdobra, portanto, como um espetáculo que o leitor meramente observa, mas é tanto um evento em processo como um acontecimento para o leitor, provocando seu envolvimento direto nos procedimentos e na encenação. (p.116).

N'Os Teclados há um jogo que leva o leitor ao ato interpretativo através da vivência dos efeitos estéticos propiciados pela presença recorrente dos elementos musicais. Estes parecem ter a função de conduzir o olhar do leitor em direção àquilo que o autor implícito parece desejar. 
Seguindo essa linha de pensamento, Júlia representaria o ideal de leitor, tal como o intérprete de uma partitura. Estar atento enquanto ouve o mundo, estar atento aos detalhes que compõem uma partitura aponta qual a conduta do leitor ideal: este deve espelhar-se na conduta de Júlia, ouvindo/lendo com atenção, sensorialidade e imaginação cada elemento (metáforas, mitos, citações, filosofias) que forma a obra literária, para, a partir daí, realizar o ato interpretativo.

Por isso, primeiramente se investiga, na narrativa, o que é ouvir; posteriormente, ouvir passa a ser sinônimo de ler. No trecho a seguir, observa-se uma tentativa de definir o ato de ouvir:

Ouvir era um segredo. Ela ouvia muitas coisas, algumas impossíveis. Por exemplo, bastava-lhe olhar a pauta para ouvir a música lá escrita. Acontecera-lhe a primeira vez com Mozart, mas verificara depois que podia ouvir qualquer música olhando apenas a partitura. Como se dentro dela alguém tocasse. Não apenas um instrumento, violino ou piano tinha a certeza de que poderia ouvir toda uma orquestra a partir da música escrita. (GERSÃO, 1999, p.13).

O fragmento narra o momento em que Júlia percebe que pode ler as partituras sem tocá-las, apenas ouvindo a música transcrita, percebendo não apenas um instrumento, mas podendo "ouvir toda uma orquestra a partir da música escrita.". O leitor, participante do jogo textual, depara-se com a possibilidade de compreender o ato de ouvir em silêncio como metáfora de ler. Assim, inicia-se, na narrativa, uma busca de definir o que seja ouvir/ler, procurando-se colocar, paralelamente, o quão frustrante será se o resultado não for bem sucedido.

Ouvir/ler deve ser uma experiência realizada no silêncio, com absoluta atenção ao ato em questão. Esta experiência deve ser realizada na mente, como um esquema virtual a ser compreendido pelo leitor, assim como a partitura é lida pelo intérprete. No fragmento abaixo, Júlia ouve os elementos do mundo, como a chuva ou o vento, mas com uma absoluta atenção a esse ato de ouvir os ruídos do mundo: 
Às vezes ela saía, logo a seguir, caminhava na rua, tocando apenas mentalmente, para não se deixar interromper. Andava pelo meio das casas e ouvia, ouvia, e ninguém dava pontapés na porta nem gritava. Então ouvia a chuva. Ouvir era uma absoluta atenção às coisas. Tudo ficava suspenso no vazio. E depois o som acontecia: a chuva, o vento, o mar. O vento nas folhas, no caminho de terra, nos telhados, na chuva. Agora ela ouvia a chuva, as formas fugidias da água [...]. (GERSÃO, 1999, p.14).

Mas o ato de ouvir, assim como o de ler, carrega um perigo, a incompreensão da obra escutada ou lida. O leitor, por exemplo, pode adentrar os vazios textuais e não conseguir sair deles para o ato interpretativo, reformulando o texto. Neste caso, o leitor acaba apresentando uma "falha" no ato interpretativo e, muitas vezes, desiste da leitura. Também, há o risco de, na experiência sensorial e afetiva da audição/leitura, o receptor deixar-se levar pelo seu caos interior. Por isso, “[...] Ela julgava compreender o perigo da energia desencadeada e solta, como um rio extravasando o leito." (GERSÃO, 1999, p.17). A imagem do rio extravasando o leito é a mesma imagem do intérprete lançado em um jogo textual em que cai no vazio textual e se perde.

Para evitar semelhante fracasso, o leitor precisaria, para realizar o ato interpretativo, adentrar os vazios textuais e reformular o texto. Logo, ele necessitaria compreender os elementos intrínsecos ao texto, que não aparecem explicitamente, mas são elaborados nas metáforas, ou ainda, nas palavras de Mário de Andrade, usando a inteligência, responsável pela apreensão da harmonia textual.

Portanto, o leitor/ouvinte deve buscar aquilo que está além da superfície, aprofundando-se no texto, estudando-o, concedendo-lhe o tempo necessário para ser compreendido. Esse aspecto pode ser percebido no trecho a seguir: "Mas quem soubesse ouvir perceberia o que estava para lá da superfície, e esta apenas dissimulava sem realmente esconder, como um pedaço de vidro transparente. [...]" (GERSÃO, 1999, p.12).

Ler/ouvir transformaria o ser humano a partir do momento em que ele realizasse o jogo do texto. Um leitor não sai de uma leitura exatamente como a iniciou, pois, a cada ato interpretativo, ele busca dentro de si elementos que o auxiliem nesta interpretação, além de reformular o próprio texto por meio de sua visão de mundo, para 
constituí-lo como objeto a ser interpretado. Por isso, ouvir/ler era um risco, na medida em que ler transforma o ser:

Ouvir era deixar o mundo entrar em si. Ficava sem defesa, escutando. O som seguia o seu curso e ela deixava de existir separadamente, tornava-se parte do que acontecia. O que era também um risco. Quase de morte, pensava às vezes. Porque a música, de algum modo, estilhaçava-a, fazia-a sair de si mesma e arrastava-a para um estágio indiferenciado, não humano, contra o qual a música finalmente triunfava. (GERSÃO, 1999, p.16).

Sobre este trecho cabe uma observação: como a arte praticada por Júlia é a música, o risco de "estilhaçamento" é maior que o que pode se dar na leitura do texto literário, que se elabora também sobre o eixo do significado.

No fragmento a seguir, aparece uma referência ao contexto. Não se pode interpretar um texto sem levar em consideração o contexto em que ele foi escrito, quais relações textuais estão impressas em suas linhas e, também, em qual contexto está o leitor, com seu devido repertório:

\footnotetext{
Mas ouvir não era separado de ver, sentir, ou entender. Nem se podia ouvir, de cada vez, uma coisa isolada, sem dar conta de que havia em volta um contexto. Se bem que era a percepção do contexto que depois fazia ressaltar, exageradamente nítida nos contornos, cada coisa per si. E também não se podia ouvir uma só vez, queria-se sempre ouvir mil vezes, depois disso. (GERSÃO, 1999, p. 15).
}

Quando o leitor está lendo, todas as metáforas, mitos, referências históricas e filosóficas presentes no texto não são analisadas e compreendidas separadamente, pois o leitor, num primeiro momento, está preso à narrativa no plano básico, isto é, o da efabulação. Quando ele inicia seu jogo textual, começa a perceber aquilo que está além da superfície do texto, ou seja, inicia a interpretação das metáforas, mitos, referências filosóficas, projeções psicológicas etc. A partir destas interpretações, o leitor passa para 
um terceiro momento, no ato da leitura: contextualizar todos estes elementos com a narrativa básica que ele acompanhava, ou seja, o enredo. Logo, o jogo do texto compõe $\mathrm{o}$ ato interpretativo em todas as suas instâncias.

Mas há leitores que não conseguem realizar essas etapas do ato interpretativo, uma vez que têm pressa para saber a "história" e se prendem somente ao conteúdo básico do enredo, sem realizar o jogo textual completo (tais leitores permanecem no que chamamos, há pouco, de leitura rasa). Por isso, em Os Teclados, o leitor é visto como "uma personagem rara", pois os leitores atuais, presos ao imediatismo, à suposta interpretação rápida, desejam "livros magros como folhetos", os ditos resumos, que prometem ensinar "Kant, Platão e Wittgeinstein em dezesseis minutos".

O leitor idealizado respeita o tempo do ato interpretativo, participando do jogo textual, buscando compreender os elementos estruturais do texto nesse sentido, segundo Compagnon (2001),

[...] o leitor implícito propõe um modelo ao leitor real; define um ponto de vista que permite ao leitor real compor o sentido do texto. Guiado pelo leitor implícito, o papel do leitor real é ao mesmo tempo ativo e passivo. Assim, o leitor é percebido simultaneamente como estrutura textual (o leitor implícito) e como ato estruturado (a leitura real). (p.151)

Ou seja, o texto apresentaria um leitor implícito como guia para o leitor empírico ou real, e no caso da obra Os Teclados, esse guia é Júlia. O leitor dessa obra, portanto, acaba sendo invadido por um questionamento sobre si mesmo, refletindo se ele se parece, de algum modo, com o leitor ideal. Nesse sentido, uma pergunta poderia ser levantada pelos leitores d'Os Teclados: será que ele, enquanto leitor d'Os Teclados, tem a percepção do leitor ideal discutido na obra pelas palavras de Helena Estevão? O leitor real ao questionar o ideal de leitor no texto, ou ao pensar sobre o comportamento de Júlia, na verdade, está pensando sobre si mesmo. E mesmo que ele não tenha o comportamento de um leitor reflexivo crítico, a estrutura narrativa do texto, através da utilização dos elementos musicais (andantes, alegros, polifonia poética, retardamento, refrão, etc.), conduz o leitor ao comportamento de um leitor ideal, pois a narrativa o 
"força" a acelerar sua leitura quando esta assim o deseja, faz com que ele desacelere essa mesma leitura quando se faz necessário; repete trechos que devam ser objeto de reflexão crítica, retarda respostas para que a crítica aconteça.

Ouvir/ler é tomar parte em algo desconhecido, que só seria descoberto no ato da leitura, por isso, ouvir/ler é um risco, pois o leitor não sabe a que levará seu ato interpretativo, uma vez que ele se dá somente entre leitor, texto e autor.

Já no final da narrativa, quando Júlia conclui que os livros, assim como a música, não trariam respostas a suas demandas, ela descreve novamente o ato de ouvir,

Ela partia para o desconhecido, mas os ouvintes iriam com ela. $\mathrm{O}$ piano era uma imensa caixa negra que ela tinha o poder de abrir, mas não lhe pertencia, era algo comum a todos, ao mesmo tempo que os ultrapassava. E se ela se aventurava a explorar o teclado, sem nunca perder o velho medo de cair dentro dele, os ouvintes corriam com ela o mesmo risco. Era isso o que ouvir significava. (GERSÃO, 1999, p.94).

Ouvir/ler era correr um risco. O risco de sofrer os efeitos estéticos do texto e, a partir do jogo do texto, elaborar o ato interpretativo, reformulando-se como pessoa. Por isso, além da constituição ética do sujeito de Júlia, tem-se na narrativa, a constituição do sujeito-leitor, metaforizado no ouvinte/intérprete projetado na figura de Júlia.

Nesse sentido, o sujeito-leitor também se pode ver nas projeções mitológicas referenciais do texto, como as sereias ou o mito de Er platônico e sartriano, já apresentados no primeiro capítulo; isto é, ele pode ter sido seduzido pelo "canto" da narrativa d'Os Teclados. Assim como pode metaforizar $\mathrm{Er}$ e sua busca pela compreensão do papel da arte e da ética, no aspecto em que ele, leitor, é levado a refletir sobre estas questões por meio dos recursos musicais como refrão, retardamento ou polifonia poética.

Reforçando os vazios do texto, em Os Teclados, outro importante efeito musical provocado pela narrativa refere-se às pausas do enredo. A pausa é um elemento musical fundamental para o destaque dos sons que compõem uma música, assim como para a ordenação do ritmo, compasso etc. Sobre a pausa na música, falou PIVA (1990): 
Em música, a pausa é o sinal com que se indica o valor do silêncio e que corresponde ao das figuras sonoras. Os músicos combinam silêncios com sons, movimentos com pausas. Segundo Gullón, o silêncio não é a suspensão da criação, mas uma circunvolução, um rodeio mental encaminhado a completar o realizado pela palavra, e que nos remete a ela. O silêncio acentua ou atenua a dicção poética de maneira precisa. A pausa é uma suspensão do discurso, tendo por finalidade reforçar o que nele se diz. A pausa pode ser definida como parada momentânea, instante em que o movimento verbal se detém para precisar o que foi dito ou chamar o que vai dizer. A pausa divide e, ao dividir, equilibra. As paradas internas exercem um papel intimamente ligado ao movimento interno da significação. (p.82)

No trecho a seguir d'Os Teclados, há uma abertura de vazio e silêncio que permite ao leitor adentrar no devaneio de Júlia, num momento de alheamento e interrupção da audição. Júlia, apaixonada, curiosamente deixa de ouvir, para contemplar a paisagem visual:

[...] Deixá-lo-ia falar, desde que ele a deixasse não ouvir. Queria apenas sentir a sua presença e olhar os rios e os barcos à vela que passavam.

Foi quando deu a trombose a Palrinha e o corpo lhe ficou tolhido de um dos lados. Não pode mais dar aulas [...] (GERSÃO, 1999, p.80).

É importante ressaltar que na Literatura, a pausa exerce a mesma função que na música, isto é, está intimamente ligada "ao movimento interno da significação", sendo indicada por sinais ortográficos, tais como dois pontos (“ : ” ); ponto e vírgula (“ ; ”); travessão (“ - “), ou ainda, especificamente em Os Teclados, com uma distância entre os parágrafos, destacando, de forma visual um vazio, portanto, a existência, ali, de uma pausa no enredo. Estas pausas visuais, ou seja, o espaçamento no texto, ocorrem em três momentos da narrativa, a primeira no trecho abaixo: 
[...] Não queria pensar. Aliás, nem teria tempo: a empregada chamava o seu nome e a única coisa de que tinha consciência era de um terrível medo da broca.

Meia hora mais tarde, de novo na rua, tudo lhe veio à ideia. As pessoas não formavam comunidades, tudo era fragmentário e no fundo indiferente, porque todos os valores eram de troca.[...] (GERSÃO, 1999, p.57).

Entre esses dois fragmentos do texto incide uma pausa espaço-visual em que o leitor se depara com a reflexão de Júlia após a leitura do encarte de jornal com a entrevista de Helena Estevão. A pausa, aqui, aponta para um salto no tempo diegético, pois omite os detalhes (sem importância) da cena vivida na cadeira do dentista, quando justamente se esquece de toda a discussão para concentrar-se totalmente, nas reações físicas e sensoriais do tratamento.

A segunda pausa já foi apresentada no trecho acima como aquela que indica a contemplação da paisagem por Júlia. A terceira pausa no texto aparece no fragmento abaixo, mais adiante na narrativa, também apontando, como no caso acima, um lapso temporal:

[...] Na última casa, quando dobrou a esquina, um gira-discos ou um rádio tocava, altíssimo, uma música de dança.

Às cinco horas entrou na sala 3. Sobre o estrado havia um piano de cauda que ela abriu, pondo o teclado a descoberto.

Mas não se sentou no banco, sentou no chão, de pernas cruzadas, encostada à parede.

Significava o quê, sentar-se e tocar? Se a sua vida fosse o que ela desejava, sentar-se diante de um teclado e tocar para um público, isso significava exactamente o quê? (GERSÃO, 1999, p.93)

Além das pausas espaços-visuais do texto, como se apontou acima, o enredo ainda apresenta diversas pausas representadas graficamente pelo travessão. Vale ressaltar que um dos símbolos de pausa na música lembra um travessão. Existem as 
pausas de semibreve ${ }^{25}$, e de mínima ${ }^{26}$, que se parecem muito com o travessão da Literatura.

No trecho abaixo, como o travessão aparece no final da frase dita por Antonieta, a mulher de Rogério Souto, que passa por um processo de luto e, na sequência, Júlia, que conversava com ela, já está fora da casa, na rua, pode-se depreender que a "pausa" no discurso é maior, como uma grande e abrupta interrupção narrativa, parecendo, portanto, uma pausa semibreve. Como se observa no trecho abaixo:

Estendeu-lhe a mão, mas a mulher beijou-lhe a face.

Obrigada por ter vindo, disse. Tenho pena de não ter podido achar o livro. Ele não teve tempo -

Quando chegou à rua olhou ainda uma vez para trás.[...] (GERSÃO, 1999, p.92) .

Já no fragmento a seguir, a pausa parece ser menor, isto é, de dois tempos, como uma mínima:

Ela continuou sentada. Paguei o teste, disse.

Mas eu não tenho tempo, disse ele irritado. Não posso perder tempo Dois minutos depois, disse ela. Eu paguei -

Comece, gritou-lhe furioso, como se já estivesse a interrompê-la gritando: Chega! (GERSÃO, 1999, p.83).

No mesmo fragmento, há a referência ao tempo de espera entre a fala de Júlia e a de Severiano Mendonça, ou seja, (“dois minutos depois”), correlativa ao tempo binário de uma pausa mínima. Além disso, no trecho "Eu paguei -" o discurso direto de Júlia parece sofrer uma inversão, e o indicador gráfico, o travessão, aparece no final da

\footnotetext{
${ }^{25}$ Pausa de semibreve: é um traço horizontal colocado sob a quarta linha da pauta. Quando um compasso não contém qualquer nota, independentemente de sua medida de tempo, preenche-se sempre com uma pausa de semibreve, que equivale a uma nota de quatro tempos. (PLATZER, Frédéric. Compêndio de Música. Lisboa: Edições 70, p.42.)

${ }^{26}$ Pausa de mínima: vale dois tempos binários de silêncio. É um traço horizontal "colado" sobre a terceira linha da pauta. (Ibid.)
} 
frase, apontando para o atropelamento discursivo entre ela e o professor Severiano Mendonça.

Também se vê a pausa que indica interrupção no enredo, como um assalto ao discurso do outro, como no caso do exemplo abaixo, onde o entrevistador "rouba" a palavra de Helena Estevão, redimensionando a entrevista:

[...] Mas, num mundo em que os valores eram de troca, tudo se tornara de certo modo indiferente. O leitor, como o escritor, tornara-se uma personagem rara -

Ia continuar mas o entrevistador interrompeu-a. Parecia agora fascinado pelas mãos: Havia pessoas que conduziam máquinas, transportavam pedras, tratavam doentes, assentavam ladrilhos - não seriam essas mãos mais úteis? (GERSÃO, 1999, p.55).

Além da pausa como símbolo do assalto ao discurso, como se viu acima, aparece, na narrativa, a pausa que controla a leitura do leitor, causando nele outro efeito estético. Trata-se da reflexão por elaborar uma espécie de andante, isto é, o leitor, diante da imagem ortográfica do travessão, realiza uma pausa maior na leitura. Logo, ao ler a narrativa mais lentamente, tem condições de refletir sobre o que está sendo lido já durante a intelecção, como se observa no fragmento a seguir:

Mas tudo o resto - claxons, vozes, sirenes, máquinas, - podia ser também uma forma de música. E mesmo o silêncio fazia parte de ouvir - o silêncio entre uma coisa e outra, a respiração ou a pausa, antes que outra coisa acontecesse.

Ouvir era deixar o mundo entrar em si. [...] (GERSÃO, 1999, p.15).

No trecho acima, o enredo realiza uma pausa na leitura do leitor, causando um efeito estético cujo eixo central é pensar sobre o silêncio. Para isso, a palavra "silêncio" se repete duas vezes além da palavra "pausa"; além disso, o fragmento possui três pausas ortográficas, representadas pelos travessões, oito pausas representadas pelos 
sinais de pontuação, sendo seis pausas menores, isto é, marcadas pela vírgula (“,”) e duas, pelo ponto final (“.”).

Mas, além das pausas gráficas, aparecem na obra as pausas ligadas ao silêncio das personagens, em que cada personagem socialmente silenciosa representa, de certo modo, uma pausa na pauta (enredo) com tempos de variada suspensão.

O leitor, ao se deparar com esse tipo de personagens, também verifica, em maior ou em menor grau, uma pausa na reflexão sobre tais personagens, uma vez que cada uma delas se demora no seu silêncio pessoal um determinado período de tempo, marcando, assim, a pausa temporal na pauta interpretada pelo narrador.

Como exemplo disso, observa-se a personagem que não domina o discurso verbal, isto é, tio Eurico, o louco, representando uma longa pausa, que, pode-se dizer, estabelece uma relação com a semibreve da música. Por não dominar o discurso, tio Eurico é considerado louco, permitindo inclusive que a sua voz fosse preenchida por outras vozes sociais, como uma pausa na melodia acompanhada por acordes na harmonia. Eurico é a grande pausa da partitura daquela casa, onde as demais personagens, tia Isaura, Armênia, tio Octávio e Júlia, formam, em determinados momentos, as notas constituintes do acorde que acompanha essa pausa melódica. Como se as relações da casa formassem uma música entrecortada por diversas pausas.

Eurico metaforiza o próprio silêncio, uma vez que ele não domina o discurso. De certo modo, ele é a concretização do silêncio que impera naquela casa, devido ao sistema opressor ali imposto pela figura patriarcal de tio Octávio. Por isso, Eurico pode ser visto como um espelho onde os "eus" da narrativa são projetados. Júlia e tio Octávio, cada um à sua maneira, expressam isso no enredo, a primeira chamando Eurico de "tio Eu", e o segundo desejando evitar a imagem destroçada de si mesmo, isto é, a figura desalinhada de Eurico. De certo modo, Eurico também potencializaria o silêncio de sua irmã, Isaura, sempre inerte, à sombra do marido, bem como o de Armênia em sua quase inexistência sonora naquela casa. Ainda se destaca, nestas duas figuras, o fato de serem meio surdas, ou seja, nesse sentido seus universos existenciais já estão imersos no silêncio como sintoma de alheamento e incomunicabilidade.

Outra voz social silenciada no enredo é a personagem Claudemiro Palrinha, também, quase inexistente. Júlia se identifica com esse professor que tenta não se submeter ao sistema mercadológico das artes na contemporaneidade, mas projeta a dor daqueles que vão de encontro ao sistema. Ele tem sua carreira musical interrompida pela artrose, o que faz com que lecione música de modo peculiar; permite a seus alunos a 
liberdade do toque, sendo ele apenas o ouvinte, destacando, quando necessário, um stacatto ou legatto. Palrinha, em sua vida frágil, contada em canários e com dedos enrijecidos, se silencia diante da música, tornando-se ouvinte silencioso das execuções de seus alunos. Ele, assim como Eurico, também é marginalizado socialmente, na medida em que não se submeteu às regras do sistema.

Por fim, o silêncio das orações de Júlia contempla as inúmeras pausas dessa narrativa. Ela, como já foi explicado no primeiro capítulo, enquanto criança, não tem coragem para enfrentar as intervenções de tio Octávio, por isso também metaforiza o silêncio, a pausa, na medida em que não se utiliza do discurso oral para se opor a tio Octávio, mas sim do silêncio do discurso religioso. É nas preces de Júlia pelo compositor Mozart que se dá a pausa talvez mais importante do enredo, uma vez que é através dela que o leitor começa a compreender os valores estéticos defendidos inicialmente pela protagonista.

Todos esses elementos músico-textuais apresentados na narrativa d'Os Teclados compõem a obra que causará efeitos estéticos no leitor, levando-o a refletir sobre sua própria condição de sujeito a ser constituído ética e esteticamente durante a leitura da obra. Logo, ler Os Teclados é passar por uma experiência estética através da narrativa e da composição musical nela presente, apontando para a constituição de um outro "eu", não só o de Júlia, a protagonista, mas também de um leitor idealizado, talvez, por Teolinda Gersão. 


\section{CAPÍTULO VI}

\section{O COMPASSO DA LEITURA}




\section{CAPÍtulo Vi}

\section{O COMPASSO DA LEITURA}

Este capítulo tem por tema de observação o tempo e como, por meio dele, a protagonista constitui-se como sujeito na obra $O s$ Teclados. Durante a narrativa, percebe-se que há a referência a pensadores que se ocuparam do tema, sendo este último um elemento estrutural basilar para a compreensão do sentido da obra. São citados Pitágoras, Kant, Platão, ou ainda, Santo Agostinho e Hume, cujas teorias são evocadas na narrativa, ainda que de maneira implícita. Caberá, portanto, a este capítulo, buscar compreender a concepção de tempo nas linhas d'Os Teclados. E, para compreender como o tempo é um elemento constitutivo da estrutura e sentido geral da obra, far-se-á uma pequena trajetória pelos conceitos sobre o tempo apontados nos escritos destes estudiosos, bem como sobre a concepção de tempo na Música e na Literatura. Estas últimas são artes que se organizam por meio do tempo. O percurso filosófico abordado na narrativa, sobre o tempo, embasará a análise deste capítulo, cujo eixo será o estudo do espaço-tempo de que Literatura e Música se utilizam para organizar suas estruturas semióticas. Paralelamente, esses eixos servirão, também, à constituição do sujeito na narrativa.

O tempo, na música, é percebido pela indicação da duração das notas e acordes musicais e compassos na partitura. O compasso é a organização temporal do ritmo, ou seja, um compasso quartenário indica que cada unidade rítmica segue a sequência musical de quatro tempos. Apesar de a música já estar dividida em um compasso específico cujas notas têm um tempo determinado, ela pode ser expressa de modo diferente conforme seu intérprete. Júlia sente-se segura ao executar uma partitura: interpretando a criação alheia, ela sente-se em terra firme:

De repente parava e abria uma partitura, como se no meio do mar achasse um caminho de regresso à terra firme. Tocar a música dos outros era aventura bastante, sentia com alívio. Sem acrescentar nem retirar uma só nota, seguindo com rigor a pauta, como se se agarrasse a fios. (GERSÃO, 1999, p.31) 
Ela sente sempre segurança ao interpretar outros compositores, pois acredita que o ato criador que é perigoso, como se percorrer o teclado sem uma trajetória pré-traçada fosse uma armadilha:

O piano era uma armadilha, que a apanhava de surpresa. Julgava brincar com o teclado, mas era o teclado que brincava com ela. No meio de uma frase, um acidente reduzia a metade a distância à nota seguinte, ou, pelo contrário, aumentava-a, uma diferença mínima, que no entanto arrastava pesadas consequências, como se o bater de asas de um insecto fizesse arrebentar uma tempestade à distância. (GERSÃO, 1999, p.30)

Júlia, ao intuir os perigos do ato criador coloca em questão a necessidade da pré-audição do intérprete para a execução da música. A interpretação musical passa pelo ato da audição, algumas vezes executado ao piano como ensaio, outras só no olhar da partitura, como é o caso de Júlia.

Nas palavras de Júlia, “ouvir era uma absoluta atenção às coisas” (GERSÃO, 1997, p.14). Para o intérprete pensar sua interpretação da peça musical, ele deve observar, dentre outras coisas, como se organizam os compassos. O tempo de cada nota, apesar de estar indicado na notação musical por seu criador, só será efetivamente fixado pelo intérprete, o que pode coincidir com a disposição - ocasional ou intencional - com que cada fruidor ouve música. Logo, pode-se depreender que a música, apesar de estar "escrita" em uma partitura, em seu espaço-tempo próprio, pode ser minimamente reelaborada tanto por seu intérprete como por seu ouvinte, caso se conceba a ideia de que o tempo musical (dentre outros efeitos) pode ser redimensionado a cada execução.

Como exemplo da diferença e personalidade na interpretação musical, tem-se, na narrativa, a descrição do ato de ouvir de tio Octávio e de Júlia. Ambos têm modos de ouvir, de perceber a música, bem diferentes. Abaixo, observa-se a audição que tio Octávio faz da música de Beethoven:

Nessa época o tio Octávio ouvia sinfonias e concertos sentado na poltrona ao canto da janela, arrancando pêlos da orelha e palitando os dentes. [...] 
Voltava depois em passos nervosos, bufava, enxugava a testa com o lenço ou assoava-se, levantava por fim com cuidado a agulha do giradiscos e voltava a colocá-la no lugar aproximado onde estivera, antes de ter sido interrompido. Sentava-se outra vez, suspirava com os olhos em alvo, como a imagem dos mártires no livro das orações, recostava-se melhor nas almofadas da cadeira e a pouco e pouco parecia adormecer, com as mãos cruzadas em cima da barriga. Beethoven, dizia no fim abrindo os olhos [...]. (GERSÃO, 1999, p.07-08)

$\mathrm{Na}$ descrição do ato de ouvir de tio Octávio, o leitor depara-se com um homem que ouve música clássica, em especial, a música de Beethoven, compositor que ele "nomeou" paradigma da boa música, a qual deveria ser ouvida em absoluto silêncio e com máxima atenção.

Já a audição de Júlia está ligada, principalmente, à natureza e aos sons do mundo. No instante em que a protagonista exercita o ato de ouvir, ela demonstra uma absoluta atenção aos detalhes dos sons escutados:

Então ouvia a chuva. Ouvir era uma absoluta atenção às coisas. Tudo ficava suspenso, no vazio. E depois o som acontecia: a chuva, o vento, o mar. O vento nas folhas, o caminho de terra, nos telhados, na chuva. Agora ela ouvia a chuva, as formas fugidias da água (a música, não a da chuva, a música em si mesma, era líquida ou aérea? Líquida, supunha. Sobretudo líquida, diria). (GERSÃO, 1999, p.14)

Júlia para para averiguar o som de cada elemento da natureza e, com atenção, percebe o som da chuva em cada um deles: "E depois o som acontecia: a chuva, o vento, o mar. O vento nas folhas, o caminho de terra, nos telhados, na chuva.". Diferentemente de tio Octávio, Júlia apega-se à audição da natureza, traduzindo uma liberdade buscada por ela, em vez de se pautar na audição da música como obra pronta e acabada, ouvida em casa, fechada em uma sala. Ela ouve com atenção cada som do mundo, enquanto Octávio presta atenção às notas executadas nas peças de Beethoven. Logo, eles têm preferências auditivas diferentes e, por ouvirem de modos distintos, a interpretação musical de cada um também não é igual.

A esse processo apresentado acima se dá o nome de fruição. A fruição aconteceria dentro do intérprete, bem como do ouvinte e, ainda, do compositor. 
Entretanto, cada um deles teria sua fruição de maneira individual, pois, apesar de se tratar de ouvir estímulos sonoros objetivos, o fenômeno da percepção é individual. Cada um deles poderá manter, no ato de fruição, elementos em comum que permitem identificar a música em questão; no entanto, o modo como o tempo da partitura será elaborado e vivenciado poderá ser diferente no ato de fruição.

$\mathrm{O}$ ato de fruição musical pode ser visto como um modo de transcendência da alma, através das sensações desencadeadas a partir do ato de ouvir. Essa fruição poderia transformar o ser humano: ou levá-lo a ter múltiplas sensações sem conseguir reordenálas, gerando caos no indivíduo; ou trazê-lo para a ordem estabelecida pelo tempo musical, reorganizando seu ser através das inflexões da escuta.

Para se compreender melhor tal efeito de reorganização que a música opera, tem-se, no romance Os Teclados, a fala do professor de matemática, Rogério Souto, que apresentará à menina esta definição sobre o tempo:

A música curava as almas porque as fazia regressar à origem, ao primeiro princípio, dizia Rogério Souto, voltando às citações. Atravessar as esferas era despojar-se, purificar-se, ficar igual a um deus. Era esse o nome dele, pensou olhando-o: Rogério Souto. (GERSÃO, 1999, p.77)

O tempo da música aparece como uma ordem transcendental que teria o poder de organizar o caos subjetivo. Esta organização assumiria a importância de manter a subjetividade dentro de um equilíbrio entre os instintos e a racionalidade. Como exemplo dessa possível transcendência, segue o trecho abaixo, em que Júlia reflete sobre o resgate de tio Eurico através do tempo musical:

Mas talvez fosse possível trazê-lo de volta, através de um trabalho de atenção. Talvez ela pudesse comunicar com ele - na verdade, quando ele marcava ruidosamente o compasso, batendo com a colher, não estava de algum modo a comunicar-se? Nesse preciso instante, ele existia. E, se conseguia existir no instante, não havia motivo para não 
conseguir existir noutros instantes e ser capaz por fim de se ligar ao tempo. Porque não fora precisamente isso que ele perdera, a ligação ao tempo? (GERSÃO, 1999, p.41)

Como se observa no trecho acima, Júlia reflete sobre a fruição do tempo musical como um elemento organizador das sensações do indivíduo, no caso, tio Eurico. O tempo funciona, aqui, como elo de ligação do sujeito com o mundo circundante.

Ainda pensando sobre o tempo, Júlia, a protagonista de Os Teclados, transmite ao leitor sua experiência de fruição musical em diversas passagens da narrativa. Ela, inclusive, apresenta a capacidade de fruição da música sem precisar executá-la ao piano, ou ainda, de atentar à fruição do ruído do mundo, ou seja, aquela percebida nos "barulhos" das ruas e da natureza. Abaixo, está transcrito um trecho que apresenta um dos primeiros instantes em que Júlia toma consciência de estar, gradativamente, desenvolvendo esta sua habilidade de fruição:

Ouvir era um segredo. Ela ouvia muitas coisas, algumas impossíveis. Por exemplo, bastava-lhe olhar a pauta para ouvir a música lá escrita. Acontecera a primeira vez com Mozart, mas verificara depois que podia ouvir qualquer música olhando apenas a partitura. Como se dentro dela alguém tocasse. Não apenas um instrumento, violino ou piano, tinha a certeza de que poderia ouvir toda uma orquestra a partir da música escrita. (GERSÃO, 1999, p.13)

Esse processo de fruição dá a Júlia a sensação de ordem interna. Quando ela se sente pressionada em sua casa, sufocada, ou quando precisa ordenar as ideias, ela "lê" a partitura e toca mentalmente; assim, através da fruição musical, ela organiza seus sentimentos, suas emoções, e ninguém poderá atrapalhar esse processo, pois ele se realiza apenas em sua mente. Por meio da música, Júlia organiza aquilo que se apresenta caótico em seu interior.

Como Júlia se organiza por meio da fruição musical, ela crê que o tempo da música tem o poder de auxiliar o sujeito a se manter em equilíbrio. Portanto, segundo a 
percepção de Júlia, a música exerceria o papel de fio condutor de um ritmo interno das pessoas, mantendo-as em equilíbrio psíquico.

Os escritos de Santo Agostinho, especificamente o livro Confissões, podem auxiliar na compreensão do modo como a protagonista concebe a dimensão temporal e interage com ela. Neste livro, Santo Agostinho se questiona sobre o tempo, como se vê no trecho a seguir:

Que é, pois, o tempo? Quem poderá explicá-lo clara e brevemente? Quem o poderá apreender, mesmo só com o pensamento, para depois traduzir por palavras o seu conceito? E que assunto mais familiar e mais batido nas nossas conversas do que o tempo? Quando dele falamos, compreendemos o que dizemos. Compreendemos também o que nos dizem quando dele nos falam. O que é, por conseguinte, o tempo? Se ninguém mo perguntar, eu sei; se o quiser explicar a quem me fizer a pergunta, já não sei. Porém, atrevo-me a declarar, sem receio de contestação, que, se nada sobreviesse, não haveria tempo futuro, e se agora nada houvesse, não existiria tempo presente. (p.322)

Santo Agostinho estuda o problema do tempo apenas sob o aspecto psicológico, ou seja, como é que as pessoas o apreendem. Para ele, o tempo não é uma sucessão de acontecimentos separados, mas sim um contínuo, isto é, uma sequência de acontecimentos ligados uns aos outros. Considerando esta continuidade, Santo Agostinho trabalha a ideia de que o tempo seria único: o presente, o passado e o futuro seriam criados a partir do tempo presente. Por exemplo, o pretérito corresponde às impressões guardadas na memória do tempo presente. Já o futuro corresponde às expectativas em relação ao presente. Portanto, ele afirma que o tempo poderá ser visto em três "partes", mas todas elas a partir da ideia do tempo presente. Este tempo presente aconteceria na alma do ser humano, ou seja, as impressões são subjetivas, variáveis e reelaboradas por aquele que pensa sobre o tempo. Sobre as articulações do tempo, observa Santo Agostinho:

[...] Mas talvez fosse próprio dizer que os tempos são três: presente das coisas passadas, presente das presentes, presente das futuras. Existem, pois, estes três tempos na minha mente que não vejo em outra parte: 
lembrança presente das coisas passadas, visão presente das coisas presentes e esperança presente das coisas futuras. (p.328)

Assim, o tempo, para Santo Agostinho, é psicológico e corresponde à impressão do antes e do depois que as coisas gravam no espírito. É o sentimento de presença das imagens que se sucedem, sucederam ou hão de suceder, projetadas sempre a partir do momento presente.

Logo, no momento em que Júlia pensa sobre fatos do passado, questionando-se sobre o futuro, como a possibilidade de um dia reordenar o caos interno de tio Eurico, ela reconhece, de certo modo, um poder de transcendência na música através do tempo e que este reorganizaria, então, as almas das pessoas. Desse modo, pode-se reconhecer nas reflexões da protagonista a presença das ideias propostas por Santo Agostinho a respeito do tempo, uma vez que ela, através da sequência intuitiva entre passado, presente e futuro, como vivências de ordenação subjetiva, tenta reordenar o caos de sua estrutura familiar. De certa maneira, ambos, Júlia e Santo Agostinho, comungam o mesmo pensamento sobre o tempo, isto é, que este é psicológico e sequencial. No trecho abaixo, Júlia, através da música, lança-se a uma experiência dos sentidos, permitindo-se vivenciar, pela música, os elementos que compõem o mundo:

Ouvir era deixar o mundo entrar em si. Ficava sem defesa, escutando. O som seguia o seu curso e ela deixava de existir separadamente, tornavase parte do que acontecia. O que era também um risco. Quase de morte, pensava às vezes. Porque a música, de algum modo, estilhaçava-a, fazia-a sair de si mesma e arrastava-a para um estágio indiferenciado, não humano, contra o qual a música finalmente triunfava. (GERSÃO, 1999, p.16)

No trecho, "Ouvir era deixar o mundo entrar em si.", percebe-se que, para Júlia, o ato de ouvir traria a experiência de sentir o mundo por meio do seu corpo, como se ela, naquele momento de audição, ingressasse num estado de meditação, e sua alma interagisse com o mundo, o cosmo, através do ato de ouvir, através da música. Era um risco que ela corria, pois a transcendência como experiência musical poderia deixá-la 
em "transe" e ela corria o risco de não retornar à sua consciência do real. Esse ato de ouvir demanda um estado de passividade que implica o abandono, ainda que temporário, da consciência. Esse estado é vivido por ela como risco, mergulho no caos.

Por conseguinte, Júlia, ao vivenciar esse tempo de percepção, grava em si as impressões que obteve sobre o mundo através da experiência musical, ou seja, o tempo é estabelecido como vivência subjetiva. Assim, para Júlia, o tempo pertence à consciência de quem o vive, ou, como diz Santo Agostinho, "Em ti, ó meu espírito, meço o tempo!"' (p.326).

Pode-se depreender, então, a música, na vivência de Júlia, como aquela que possibilita levar o ser humano a uma "viagem" transcendental a partir da qual apenas as sensações triunfam e, por meio delas, pode ocorrer a transformação do ser humano dotado de atenção e sensibilidade.

Mas a música, apesar dessa transcendência através dos sentidos, teria uma outra função, a de trazer de volta o indivíduo que embarcou em sua própria viagem sensitiva. Ela é construída através do tempo e, portanto, ela, de certo modo, força as sensações a obedecerem à sua medida, organizando o caos instaurado, por meio do tempo. Logo, ao mesmo tempo em que a fruição musical levaria o ouvinte ao caos interno, pois despertaria uma diversidade de sensações, ela também o traria ao equilíbrio, condicionando tais sensações à organização do tempo musical. No trecho transcrito abaixo, aparece a ideia da cura pelo contato proporcionado com esse caos original, essa camada pré-consciente da percepção:

A música curava as almas porque as fazia regressar à origem, ao primeiro princípio, dizia Rogério Souto, voltando às citações. Atravessar as esferas era despojar-se, purificar-se, ficar igual a um deus.

Era esse o nome dele, pensou olhando-o: Rogério Souto. (GERSÃO, 1999, p.77)

Neste segundo trecho, através da intuição de Júlia, o leitor pode perceber a ideia da cura pela organização do caos interior, através de uma marcação temporal dada pela música: 
Mas talvez fosse possível trazê-lo de volta, através de um trabalho de atenção. Talvez ela pudesse comunicar com ele - na verdade, quando ele marcava ruidosamente o compasso, batendo com a colher, não estava de algum modo a comunicar-se? Nesse preciso instante, ele existia. $\mathrm{E}$, se conseguia existir no instante, não havia motivo para não conseguir existir noutros instantes e ser capaz por fim de se ligar ao tempo. Porque não fora precisamente isso que ele perdera, a ligação ao tempo? (GERSÃO, 1999, p.41)

A transcendência pela fruição dar-se-ia pelo tempo, "e ser capaz por fim de se ligar ao tempo. Porque não fora precisamente isso que ele perdera, a ligação ao tempo?” pensava Júlia, assim como Rogério Souto apresentou a ideia de que a música curava as almas, "A música curava as almas porque as fazia regressar à origem, ao primeiro princípio...".

No trecho a seguir, percebe-se que Júlia se permite, através do ato de ouvir, alcançar a fruição musical e lançar-se às sensações desencadeadas por ela: " [...] a música era uma forma de ultrapassar o caos, obrigando-o a caber numa medida. Ouvir era também isso: tomar parte na luta entre a medida e o caos.” (GERSÃO, 1999, p. 16)

Passando pela experiência de fruição musical, através da audição das peças musicais ou dos sons do mundo, Júlia vive; pela reflexão, alcança um entendimento epifânico do processo, na sua complexidade e contradição: ao mesmo tempo em que leva seu ouvinte, através da fruição musical, a sentir a transcendência do ser, ela também resgata esse ouvinte, prendendo-o ao tempo de execução da música e ao tempo de cada nota executada. A música lança o ouvinte no caos e o retoma por meio do tempo, ou seja, "toma parte na luta entre a medida e o caos" (p.16).

A partir da epifania de Júlia, resumida no trecho acima, ela inicia uma reflexão sobre a possibilidade de "salvar" tio Eurico dessa imersão de sensações desordenadas em que ele vive o tempo todo.

A convivência com esse tio perdido em seu caos interior dá à menina a noção do risco que sua sensibilidade musical representa: 
Não lhe disse que tinha medo de se afogar no teclado. De desaparecer dentro dele. Não lhe falou do seu medo de improvisar, das frases que lhe andavam na cabeça e mesmo em sonhos voltavam e não achavam solução até implodirem ou explodirem dentro dos sonhos, não lhe disse que antes de tocar estava já a ouvir o modo exacto como deveria soar cada nota, ela ia atrás do som interior como atrás de uma luz, com a sensação desesperada de não a poder alcançar nunca. (GERSÃO, 1999, p.48-49).

Esta ideia do resgate terapêutico do ser (no caso da narrativa, tio Eurico) através da música, é a intuição de Júlia sobre o poder do tempo, quando concebido esteticamente. Posteriormente, a ideia curativa será confirmada pelas palavras de Rogério Souto, seu professor.

Essa concepção de tempo que pode resgatar Eurico de sua loucura pode ser esclarecida recorrendo ao Timeu, de Platão. Durante a narrativa d'Os Teclados, Platão é citado algumas vezes, bem como algumas de suas teorias. A seguir, tem-se uma sucinta explicação sobre a teoria platônica sobre a criação do universo e do tempo. Essa teoria é explicada a Júlia por seu professor de matemática Rogério Souto.

Platão tratará do tempo a partir de uma concepção musical, a chamada harmonia das esferas. Segundo Platão, em seu livro Diálogos - Timeu, Crítias, As Leis, Timeu, o mais versado de todos os interlocutores nas ciências, irá expor a formação do universo. É por meio de uma ficção que Timeu apresentará aos ouvintes a origem do Universo:

[...] Ora o artífice sendo bom e desprovido de inveja, resolveu ordenar o devir constituindo a alma e o corpo do mundo e uniu-os em um grande ser vivo, o Todo, o ser completo que contém em si todos os demais seres vivos. [...] A seguir, envolveu estes corpos na Alma do Mundo, mais antiga, maior do que ele. Para formar esta alma, tomou inicialmente duas essências: a essência imutável e a essência mutável. [...] formou dois círculos concêntricos e cruzados, um no exterior, no plano do Equador e outro no interior, inclinado sobre o primeiro, em ângulo agudo, no plano da Eclítica. Ao círculo exterior ele imprimiu um movimento uniforme, o do mesmo, de Este para Oeste. O círculo interior é formado de diversos círculos concêntricos de largura desigual e exatamente encaixados uns nos outros e comporta diversos movimentos dirigidos de Oeste para Este (p.42) 
Cada ser humano, segundo a teoria platônica, teria parte na alma do Mundo (“[...] constituindo a alma e o corpo do mundo e uniu-os em o grande ser vivo, o Todo, o ser completo que contém em si todos os demais seres vivos."). Para que esta alma, formada por várias partes, fique sempre harmônica, cada ser, pertencente a ela, deve obedecer às regras da polis, garantindo assim, a harmonia das esferas. No entanto, caso uma alma esteja fora dessa harmonia, ela interferirá diretamente na alma do Mundo, gerando caos. Como a alma do Mundo é formada por diversos círculos, e cada um deles mantém um movimento contínuo, aquele ser que desenvolve um movimento contrário ao pré-estabelecido pela harmonia das esferas acaba atrapalhando todo o conjunto de movimentos, ou seja, caso a alma não obedeça àquilo que mantém esta harmonia (no caso as leis da polis) ela causará uma desarmonia no Todo, ou ainda, se ela estiver em desarmonia consigo, esta também interferirá na harmonia do Todo ou da alma do Mundo.

Esta teoria de Platão sobre a criação do universo refere-se à ideia da harmonia das esferas. Cada círculo que forma a alma do Mundo tem um planeta. Estes planetas estão ligados por um fio. Em cada planeta há uma sereia que entoa uma nota musical. Devido à música entoada, os planetas que comporiam o universo apareceriam dispostos em uma espécie de escala musical. A harmonia das esferas é estabelecida pelo tempo ou intervalo de rotação entre as esferas. Os planetas presentes nos círculos são sete (Lua, Sol, Vênus, Mercúrio, Marte, Júpiter e Saturno). Os círculos possuem velocidades diferentes, e estas estão harmonicamente organizadas, elaborando a música do mundo, ou a harmonia das esferas. Caso alguém não obedeça à ordem estabelecida, isto gera o caos. Quando alguma alma gera o caos, devido à sua desarmonia, para realinhar-se, ela deverá se harmonizar com o tempo da música entoada e com a velocidade dos círculos onde estão os planetas; logo, somente a música, através do seu tempo, seria capaz de reordenar o indivíduo, retirando-o do caos.

Júlia acredita, interpelando o tio Eurico, que a comunicação faz as pessoas existirem no mundo, ligando-as, de certa forma, à harmonia social que Platão identifica como polis: "Talvez ela pudesse comunicar com ele [...] Nesse preciso instante, ele existia" (GERSÃO, 1999, p.41). O fato de Eurico não se comunicar o deixa à margem da sociedade, como se ele não existisse. Júlia acredita que a música, através da marcação do compasso ("na verdade, quando ele marcava ruidosamente o compasso, batendo com a colher, não estava de algum modo a comunicar-se?"), pode resgatar Eurico do caos, da ausência de comunicação, do fato de não pertencer ao círculo social 
por ser considerado louco. Esta percepção de Júlia, neste instante da narrativa, ainda se dá através da intuição. Posteriormente, como já foi argumentado no início deste capítulo, Júlia, por meio das palavras de Rogério Souto, perceberá que seus pensamentos estão alinhados com teorias filosóficas muito antigas, formadoras de um conhecimento cujo alcance não pode dimensionar.

O fato de Eurico não dominar a comunicação e ter um comportamento inadequado às normas sociais vigentes estigmatiza-o como "louco", gerando vergonha e irritação em seu lar. Prova disso, é a revolta de Tio Octávio ao ver o cunhado em uma situação vexatória, andando como maltrapilho pelas ruas:

Mas o tio Octávio não estava de acordo: a figura de tio Eurico pedindo esmolas nas ruas, de casaco puído e olhar vago, parecia-lhe uma violação da sua própria intimidade. Preferia por isso escondê-lo nas profundidades da casa. (GERSÃO, 1999, p.18).

[...] Era sobretudo por causa da respeitabilidade que insistia em fechar tio Eurico com uma corrente e um cadeado portátil [...] Não podia admitir que outras pessoas vissem o cunhado que lhe coubera em sorte, de ar aparvalhado, camisas sujas de terra, bolsos do casaco a transbordar de folhas. [...] e sobretudo exasperava-o que fugisse de casa e se oferecesse, em espetáculo, na rua. (GERSÃO, 1999, p.38).

Tio Eurico é a personagem que simboliza a loucura humana na sociedade contemporânea. Ele tem atitudes que fogem às convenções sociais - por exemplo, ele come com as mãos, coloca fogo nos móveis, assusta as pessoas e grita muito. Também anda como maltrapilho e não estabelece nenhum contato com o mundo através de palavras. Para os parâmetros culturais, Eurico enlouqueceu na medida em que ele foi perdendo a capacidade de estabelecer relações com o mundo. Tomando como base o pensamento de Platão em Timeu, Eurico poderia ser visto como aquele que teria a alma em desconcerto com a harmonia da Alma do Mundo, e a música seria, ao menos no entendimento de Júlia, um modo de resgatá-lo.

Ao mesmo tempo, Júlia, que, dentro de sua casa, sempre está em silêncio, apenas ouvindo e observando os acontecimentos do lar, também projeta esta sua 
condição silenciosa na imagem de Eurico, cujo mutismo é entrecortado, apenas, por seus gritos. Ela percebe, em seu próprio comportamento, semelhanças com tio Eurico, como se pode ver na tendência a sair pela rua sem rumo, ouvindo a "música do mundo":

A ideia de que era igual a ele, de que podia enlouquecer como ele. Também ela fugia de casa, vagueava pelas ruas, se fechava no quarto, escondia segredos. Também a ela alguma coisa a assaltava, a música era uma onda de energia desencadeada e solta à mercê da qual ficava sem defesa. O tio eu. (GERSÃO, 1999, p. 39-40)

Por reconhecer nas atitudes de Eurico algumas das suas próprias atitudes, Júlia tem medo de enlouquecer como ele. Por conseguinte, ela o chama de "Tio Eu", um espelho de seu ser.

Primeiramente, Júlia constata que considerar Eurico louco ou não dependeria daquele que o visse. Ela considera Eurico louco depois de observar que ele não domina o discurso, as palavras. Eurico seria chamado de louco porque não domina o discurso organizado e, portanto, não consegue se comunicar com a sociedade. Prova disso é que Eurico tenta estabelecer com Júlia alguma comunicação, mas não consegue. Essa tentativa dar-se-ia por meio da música, em especial, o tango Camiñito, através das batidas fortes do tango, marcando o compasso, isto é, a sua organização temporal. Júlia tentava resgatar tio Eurico, e ele, por sua vez, buscava encontrar uma forma de se comunicar, acompanhando as batidas do tango com uma colher de pau. Mas o mundo de Eurico parecia já caótico demais para ser reordenado: logo em seguida, ele voltava ao seu estado de isolamento externo e interno. No trecho abaixo, comprovam-se as tentativas de Eurico em se comunicar através das batidas de uma colher de pau nos móveis da casa:

Bata comigo o compasso, disse de súbito, batendo as palmas. Ele não pareceu ouvir, continuou parado, encostado à parede, com a cabeça caída sobre o peito. Ela bateu outra vez, marcando um ritmo, e como ele continuou sem dar acordo, levou-o pela mão para a sala, sentou-se no banco do piano e tocou as primeiras frases do tango 
Camiñito. Uma vez e outra, até que ele pareceu entender, correu a buscar a colher de pau e começou alegremente a bater nos móveis. (GERSÃO, 1999, p.41- 42)

Apesar das tentativas de Júlia, Eurico bate aleatoriamente a colher de pau nos móveis, não há lógica, não há ordem, não há tempo organizado e, portanto, é frustrada a tentativa de comunicação. A loucura é, portanto, subentendida como ausência de ritmo.

Devidos às suas tentativas frustradas em relação a Eurico, Júlia conclui que a afirmação: “A música curava as almas.”(GERSÃO, 1999, p.78) não era verdadeira no caso de seu tio. No início, ela ainda buscou, através da música (como forma de comunicação e ordenação do indivíduo), resgatar Eurico do caos, mas não conseguira. Segue-se a conclusão frustrada de Júlia:

A música curava as almas. Ela também acreditara isso. Tentara curar o tio Eurico, prendê-lo de novo ao tempo. Mas ele permanecera desligado. Por muito que ela se esforçasse, nunca iria trazê-lo de volta. Não tinha esse poder.

E a música também não tinha esse poder. Era tudo ilusão, pensou. $\mathrm{O}$ mundo talvez não fosse um cosmos, um universo ordenado. Provavelmente não tinha medida, nem escapava ao caos. (GERSÃO, 1999, p.78).

Nesse instante da narrativa, além da frustração de não conseguir resgatar Eurico, Júlia também pergunta se o poder da música em curar as almas seria verdadeiro ("E a música também não tinha esse poder."), e também questiona a teoria da harmonia das esferas de Platão ("O mundo talvez não fosse um cosmos, um universo ordenado. Provavelmente não tinha medida, nem escapava ao caos.”). Mais adiante na narrativa, Júlia reafirma a teoria platônica de que dentro de cada ser existiria um som que faz parte do som da Alma do Mundo e, portanto, todos os seres humanos seriam controlados pela música do universo: “[...] E ela não seria manipulada, porque nunca se deixava manipular. A não ser pelo universo. O mistério do som passava através dela. A misteriosa divisão da corda." (GERSÃO, 1999, p.94).

Toda essa abordagem aqui realizada, sobre Júlia e sua epifania em relação à cura das almas pela música, traz à tona a discussão sobre o tempo na música, na literatura, e, 
também na filosofia, e ajuda o leitor a percorrer, com a protagonista, seu caminho de autodescoberta e de descoberta da sua ligação com o universo.

Muitos autores, ao longo da história, questionaram-se sobre o tempo, mas quase todos eles, de modos diferentes (teorias), concordam em um aspecto: "o tempo é particularmente significante para o homem porque é inseparável do conceito do eu." (MEYERHOFF, 1976). O tempo, na concepção aqui já apresentada, de Santo Agostinho, parece explicar melhor uma das principais discussões ocorrida em $O s$ Teclados, a construção ética de um sujeito, no caso, Júlia.

Tal construção se inicia quando ela ainda criança questiona, em seus pensamentos, a imposição do gosto musical de seu Tio Octávio. A partir deste dado, o leitor acompanha a formação de Júlia como sujeito, adentrando sua mente, numa espécie de monólogo interior, verificando as análises realizadas pela personagem em relação a cada membro que compõe sua família e, posteriormente, a cada pessoa que compõe seu universo social, dentre amigos, professores e personagens eventuais, como a trapezista, a escritora Helena e os filósofos cujas teorias lhe são apresentadas pelo professor de matemática.

Segundo Meyerhoff (1976), “O que chamamos de eu, pessoa ou indivíduo, é experimentado e conhecido somente contra o fundo da sucessão de momentos e mudanças temporais que constituem sua biografia." (p. 01). Ou seja, o tempo faz o "eu" existir. Júlia está presa ao tempo de diversas maneiras. Primeiramente, porque ela se envolve com uma arte temporal - a música - e, portanto, está habituada a organizar a sequência de notas que compõe a música por ela executada. Esta "disciplina" musical, Júlia acaba aplicando em sua vida, tentando ordenar o mundo que a cerca para o compreender, como se estivesse escrevendo uma partitura de sua vida, e, assim, entender a si mesma. Em segundo lugar, Júlia é uma personagem de ficção cuja vida está sendo exposta a um leitor, por conseguinte, o autor organizou a vida de sua personagem dentro do tempo da narrativa.

Júlia é a protagonista de um romance de aprendizagem. Em cada cena lida pelo leitor, a personagem reflete sobre diversos temas (a música, o amor, a loucura, a opressão, a indústria cultural etc) e, a partir da aprendizagem resultante destas reflexões, ela constitui-se eticamente, de forma gradual, como sujeito.

Tomando-se como referência a teoria agostiniana acerca da relação entre o tempo e a constituição do sujeito, o ato de refletir a todo momento, sobre os acontecimentos de sua casa ou de sua escola, prendê-la-ia ao tempo e possibilitaria que 
a sua formação como sujeito fosse resultante da "lembrança presente das coisas passadas, visão presente das coisas presentes e esperança presente das coisas futuras." (Santo AGOSTINHO, p. 328).

Para se compreender melhor como Júlia, por meio do tempo, constitui-se como sujeito, faz-se necessária uma explicação sobre os vários conceito de ética que se podem depreender na narrativa de Teolinda Gersão. Segundo Pivatto (2004),

\begin{abstract}
A ética, historicamente, foi e é (ainda) compreendida como a compilação de princípios, valores e normas que os indivíduos têm que observar para manter uma conduta boa, decente, legal ou normal. A ética, nesta perspectiva, seria o saber que prescreve o que os indivíduos devem fazer, como devem fazer e quando devem fazer. A ela corresponderia o espaço da normatividade consuetudinária, do valor, do costume e do hábito considerado bom e justo. A esta perspectiva podemos denominar de ética do código. (p. 97)
\end{abstract}

Pela definição de Pergentino S. Pivatto, percebe-se que a "ética de códigos" é mutável conforme a época e os valores tidos como "bons e justos" para determinada sociedade ou microssociedade (como é o caso de uma família, escola, igreja etc).

Júlia, desde o início da narrativa, busca parâmetros de conduta, refletindo sobre os valores que compõem a "boa música" em sua casa. Ela não concorda com a opinião de seu tio Octávio, que estabeleceu Beethoven como paradigma musical, mas ela, ainda uma criança, não verbaliza sua oposição a esse tio; apenas no olhar e nos seus pensamentos é que Júlia nos dá a conhecer seus questionamentos em relação ao modelo ético estabelecido pelo tio.

Ele, por sua vez, deixa claro para Júlia que tem o poder de preescrever a conduta daquela casa, exercendo sua posição social de "patriarca". O fato de ele rir ironicamente para Júlia, erguer o dedo indicador como se estivesse dando uma ordem a ser cumprida sem questionamentos, mostra que a construção do código ético do lar de Júlia está nas mãos de tio Octávio. Aquele que não se enquadra nestas normas é visto como "anormal". Segundo Pivatto, 
A disputa de poder se trava em torno da definição do que é normal, do estabelecimento da norma que define a normalidade (ética) e, consequentemente, a legalidade jurídica. É uma disputa pela apropriação dos dispositivos de produção da ética que outorga o poder (simbólico-político) de constituir a norma como o espaço da normalidade e seu desdobramento, a legalidade, como reafirmação do que uma sociedade considera normativamente aceitável ou reprovável. (p. 99)

Em torno da figura de tio Octávio se concentra a discussão sobre a normatividade e o poder, para ver quem, afinal, acabará por determiná-lo aos olhos de Júlia. Esta disputa de poder, em grau menor, de forma silenciosa, é realizada entre tio Octávio e Júlia. Ela não aceita as normas estabelecidas por ele - e que na narrativa comumente se aplicam ao campo do gosto, confundindo-se, portanto, com normas estéticas. Tio Octávio determina que Beethoven é o grande mestre a ser seguido; o silêncio deve coexistir com a execução das músicas de Beethoven; as mulheres devem executar as tarefas domésticas; e a música deve ser apresentada em público pelo executante como um "triunfo social", ou seja, como status em relação às demais pessoas que partilham da audição executada ou por ele, ou por tia Isaura, ou por Júlia. No trecho que se segue, a figura de tio Octávio transmite uma imagem caricata do ouvinte seleto: "Nessa época o tio Octávio ouvia sinfonias e concertos sentado na poltrona ao canto da janela, arrancando pêlos da orelha e palitando os dentes. [...]“ (GERSÃO, 1999, p. 07).

É interessante perceber que, na narrativa, quando tio Octávio está ouvindo Beethoven, ele projeta sua raiva e irritação na fruição da sinfonia: “[...] Estafermos, diziam os violoncelos. (Sem vir um cretino estragar tudo, repetia, mais alto, o primeiro violino, numa voz aguda). Vão para o inferno, vão para o inferno, ameaçavam, em coro os contrabaixos." (GERSÃO, 1999, p.08). Pela própria experiência de audição, o leitor pode perceber que Beethoven permite isso, nos movimentos mais densos, vibrantes e percussivos de sua música. Desse modo, é possível ver nessa "audição projetiva" uma espécie de ruído, uma vez que a personagem não se dispõe plenamente à recepção, antes, quer ouvir o reflexo de suas próprias emoções; e encontra em Beethoven, portanto, um suporte adequado para extravasar o temperamento colérico que possui.

Em contrapartida, Júlia encontra na música de Mozart também um suporte em que reverberam a delicadeza e a naturalidade da menina sensível e espontânea que ela é. 
Logo, ela internaliza outro paradigma ético-estético, que ela própria estabelece. Ela elege Mozart como o grande mestre a ser seguido; a música como um ato de transcendência do "eu" (através da fruição musical plena); e não se vende a nenhum público, negando o status social que tio Octávio prestigia. Quando o leitor entra em contato com o modo de ouvir de Júlia, percebe-se que há uma mudança em relação ao modo de ouvir de Tio Octávio, pois o leitor pode observar uma certa delicadeza na descrição da performance auditiva da menina, ao contrário do que se percebe nas palavras, de certo modo, ofensivas projetadas sobre um significante musical como "estafermos, cretino". Segue-se o trecho:

\footnotetext{
Então ouvia a chuva. Ouvir era uma absoluta atenção às coisas. Tudo ficava suspenso, no vazio. E depois o som acontecia: a chuva, o vento, o mar. $\mathrm{O}$ vento nas folhas, o caminho de terra, nos telhados, na chuva. Agora ela ouvia a chuva, as formas fugidias da água (a música, não a da chuva, a música em si mesma, era líquida ou aérea? Líquida, supunha. Sobretudo líquida, diria). (GERSÃO, 1999, p.14).
}

No trecho acima, os fonemas $(n, m, s, z,, f, l)$ além dos dígrafos $(l h, n h)$ traduzem a fluidez, o escorregamento ou a lentidão na execução da leitura das mesmas. Trata-se de um trecho bastante poético, graças à riqueza sonora de suas palavras: ouvia,

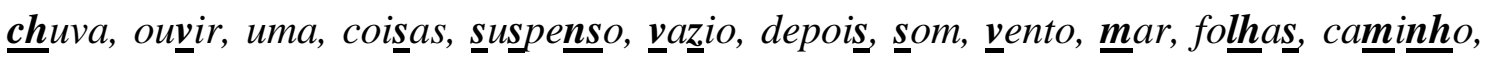

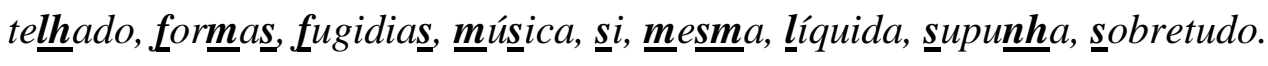

Por sua vez, percebe-se que a tio Octávio apetecem as oscilações bruscas entre o grave e o agudo. Os trechos a eles dedicados são mais truculentos, além disso, sempre que está a ouvir, tio Octávio é, de algum modo, interrompido por outro som irritante e assustador, como os gritos de tio Eurico. Já Júlia integra a seu modo de ouvir elementos da natureza, como o vento ou a chuva. Tio Octávio parece estar preso a uma ordem instrumental rigorosamente construída, enquanto Júlia estaria em liberdade e doação. Por isso, ele sempre está a ouvir fechado dentro de casa, enquanto Júlia está fora, captando a música da natureza. Essas diferenças apontam uma possível luta entre os paradigmas ético-estéticos estabelecidos por cada um na obra. A seguir um trecho que aponta a luta relatada acima, entre tio Octávio e Júlia: 
Beethoven, dizia no fim abrindo os olhos e levantando o dedo indicador, quando finalmente a música parava. E olhava para ela, com um riso escarninho, satisfeito como se tivesse ganho uma batalha. (GERSÃO, 1999, p.08).

[...] Ela não respondia, engolia a resposta e a raiva. Levantava a cabeça, desafiando-o, sem dizer uma única palavra. Mas à noite rezava por Mozart. (GERSÃO, 1999, p.10).

Porque os valores estéticos são diferentes, Júlia estabelece esta luta em seus pensamentos, em seu silêncio e em algumas atitudes relacionadas ao ato de tocar. Por exemplo, finge errar as partituras, não toca inteiramente uma música que acabou de aprender só de escutar e simula, com isso, a imagem de uma menina que perdeu seu "dom" musical - desse modo, esforça-se por ser autêntica e por libertar-se das amarras do tio. Mas, enquanto criança, ela ainda precisa obedecer ao código ético determinado por ele, por isso ainda tem de treinar as escalas musicais e vai às aulas de piano indicadas por tia Isaura.

Tio Eurico é, no núcleo familiar, aquele que não se enquadra em nenhum código ético. Sob esta perspectiva, ele é o anormal, ou seja, aquele que não consegue apreender nem seguir as normas da casa. Nas palavras de Pivatto, “[...] A norma (ética) confere uma aparência de normalidade àquilo e àqueles que se ajustam a seu ditado.” (p. 99). Assim, todo aquele que não se enquadra nas normas estabelecidas de uma sociedade é visto como anormal, como é o caso de tio Eurico.

Júlia, na busca de construir para si valores, crê na possibilidade de resgate de tio Eurico através da música, ligando-o ao tempo musical, ao contrário do que fazia tio Octávio, trancando-o no quarto para escondê-lo da sociedade. Para Isaura e Octávio, Eurico representa uma vergonha social. Observa-se essa "vergonha" no trecho, em que Octávio, para continuar sendo respeitado pelas pessoas, prende tio Eurico: "Era sobretudo por causa da respeitabilidade que insistia em fechar no quarto o tio Eurico com uma corrente e um cadeado portátil [...]” (GERSÃO, 1999, p. 38).

A organização do ser humano a partir do tempo musical faz parte do caminho ético de Júlia. Ela acredita que há uma música do universo, a música do mundo e, a partir dela, unindo-se ao tempo, o ser humano reorganizaria a sua alma. Nas palavras de Júlia, “A música curava as almas” (GERSÃO, 1999, p.78). 
$\mathrm{Na}$ narrativa, pode-se deparar com outras formas de conceber a interligação entre o sujeito e o tempo. Mas em todas elas se depreende uma organização do ser humano. Exemplo disso é Claudemiro Palrinha, que estabelece com o tempo uma relação peculiar. Ele mede o tempo em canários, ou seja, o tempo de vida de um canário corresponde a uma unidade temporal específica para Palrinha.

Calcula-se que um canário viva em torno de seis anos - uma unidade peculiar para a contagem de tempo de Palrinha:

Depois disso comprara um canário, disse ele. A partir de uma dada altura passara a ter sempre um canário, logo que um morria comprava outro. Quando estava bom tempo pendurava a gaiola na parede exterior da casa, do lado de fora da janela, à noite cobria a gaiola com um pano. A sua vida passara a medir-se em canários. Um, dois quatro, seis canários. Calculava que ainda viveria dois ou três canários mais. (GERSÃO, 1999, p.50).

O Palrinha seria, segundo esta mensuração de tempo, um jovem professor em torno de trinta e seis anos ("Um, dois quatro, seis canários"), que acreditava que viveria mais doze ou dezoito anos, ou seja, chegaria próximo dos quarenta e oito ou cinquenta e quatro anos de idade (“[...] viveria dois ou três canários mais.”). Para Júlia, Palrinha seria como Mozart. Assim como este aprendera muito com os pássaros, ele ouvia atentamente seus canários. Ambos são relevantes referências no universo ético/estético que vai sendo construído no interior de Júlia.

Diferentemente da imagem do homem que sofre de artrose e comporta-se de maneira sóbria e discreta quando leciona para as "burguesinhas", esta faceta do professor de Júlia organiza-se a partir de um vínculo com o tempo da natureza, que é livre, espontâneo e prazeroso. Assim, este Palrinha é o que assobia pelas ruas, que deixa Júlia tocar à vontade e parece possuir em si mesmo cada um dos canários que viveram em sua casa (é como se os canários fossem a representação metonímica de um Palrinha mais livre, naturalmente musical).

Outra concepção do tempo é expressa pela escritora Helena Estevão na entrevista concedida ao jornal com que Júlia se distrai no dentista. Aqui, o tempo não é mais abordado no sentido psicológico, mas sim cronológico. Trata-se do tempo que 
controla o dia-a-dia das pessoas, ou seja, o tempo do calendário, o mesmo que demarca períodos históricos.

Helena reflete sobre a modernidade e sobre como o tempo, para as ações das pessoas, em seus cotidianos, está encurtado, devido aos valores da sociedade capitalista que o dimensiona e o controla. Esta sociedade apoia-se sobre o valor de troca, o valor de mercado, e todas as ações nela executadas passam por este valor.

Helena Estevão reflete sobre a indústria cultural e como o tempo teria sido "terrivelmente encurtado" nessa sociedade contemporânea. Como já foi explicado no capítulo II, a indústria cultural trabalha a ideia social de que a arte é um direito de todos. Com isso, promove a reprodutibilidade de obras de arte sem a preocupação com o conhecimento contemplativo em face de sua "aura", ou ainda, se reinventa a "arte". Segundo Marilena Chauí, em seu livro Convite à Filosofia,

A indústria cultural vende cultura. Para vendê-la, deve seduzir e agradar o consumidor. Para seduzi-lo e agradá-lo não pode chocá-lo, provocálo, fazê-lo pensar, fazê-lo ter informações novas que o perturbem, mas deve devolver-lhe, com nova aparência, o que ele já sabe, já viu, já fez. A "média" é o senso-comum cristalizado que a indústria cultural devolve com cara de coisa nova. (p. 330)

Nesse sentido, no trecho a seguir, Helena comenta sobre os livros que anunciam a possibilidade de estudar grandes filósofos de maneira rápida, quase instantânea: "Era verdade que o tempo parecia ter sido terrivelmente encurtado (Kant, Platão, Wittgenstein em dezasseis minutos, prometiam livros magros como folhetos)." (GERSÃO, 1999, p. 54)

O tempo, para Helena, é violentamente modificado a partir do desenvolvimento da indústria cultural. Agora, na melhor das hipóteses as pessoas se preocupam com ostentar o status de possuir uma obra de arte, como coleções de música clássica, reproduções de quadros na parede, livros nas estantes, esculturas nas salas. Mas, na grande maioria da população, tais objetos servem apenas para indicar status social. Não se cultiva o tempo para a aprendizagem requerida pela obra de arte. No caso dos livros, 
são vendidos nas bancas de jornais os resumos dos mesmos ("prometiam livros magros como folhetos."), as pinturas e as esculturas são vistas como objetos de decoração. Já a música, sobretudo a clássica, apresenta um inconveniente para esta sociedade da velocidade, do imediatismo: não há a possibilidade de resumir a música nem de acelerar a sua execução. Como ela é toda construída a partir do tempo, para ouvi-la, é necessário esperar o tempo de execução de cada compasso. No caso da nona sinfonia de Beethoven, por exemplo, o ouvinte, para ouvi-la na íntegra, precisa esperar o tempo da execução de movimento, e caso o intérprete execute um trecho apenas, ele não terá resumido a música, mas apenas terá tocado um fragmento dela.

O conceito de tempo muda na modernidade, tanto quanto o status do indivíduo, pois é ele o foco das mudanças do significado do tempo devido às transformações ideológicas, sociais e tecnológicas do mundo moderno. O homem passa a ser visto como unidade cumulativa de produção nesta modernidade, ou mais exatamente, como unidade de produtividade. Logo, o indivíduo

vale o preço que consegue extrair no mercado; não no sentido literal do mercado de escravos, certamente, mas no sentido mais amplo de que o valor humano é predominantemente uma função da produtividade e sucesso humanos definidos segundo a complexa superestrutura do mercado. (MEYERHOFF, p. 100).

Desse modo, o tempo (visto como uma mercadoria à semelhança dos bens produzidos no tempo) converte o próprio homem em mercadoria. O homem moderno vê o tempo com valor instrumental, como unidades de produção. Passa, portanto, a crer que estes fragmentos de tempo que constituem a história da vida de uma pessoa (conceito agostiniano) também possuem valor de mercadoria, ou seja, têm valor instrumental e não intrínseco.

Marx foi um dos primeiros autores a desenvolver a concepção do homem como resultado de uma sociedade industrial moderna. A psicologia social contemporânea também estuda nossas novas conceituações linguísticas do tempo, tais como nossa distribuição proporcional de valor do tempo (salários de acordo com o tempo de 
produção; aluguel; juros; taxas etc.); há ainda nossa ênfase em "poupar tempo", ou seja, uma supervalorização da velocidade do tempo em detrimento da lentidão que desvalorizamos como "monotonia" e sensação de perda. São valores que vemos já consagrados desde o emblemático filme Tempos Modernos, em que Chaplin apresenta um retrato crítico do indivíduo como unidade produtiva em uma linha de montagem.

Com este novo modo de visão do tempo, a arte em geral (Música. Literatura, Dança, Pintura) passa por uma desvalorização intrínseca dada por sua reprodutibilidade $^{27}$, ao mesmo tempo em que reduz a sustentar um certo status social a partir de sua aquisição.

De acordo com esta concepção de tempo, observa-se a impossibilidade plena de fruição da obra de arte, pois ela demanda um tempo específico de vivência interior da emoção estética. Por exemplo, a Música tem seu tempo de execução, a Pintura, de observação e a Literatura, seu tempo de leitura. Quando se resume uma obra literária ou se executa ou escuta apenas um fragmento de uma música, não se está apreciando legitimamente a obra como construção estética. Em Os Teclados, Helena questiona esta prática do livro fácil, que promete ensinar a filosofia de grandes autores de forma rápida (“dezasseis minutos”). Saber resumir o enredo de uma narrativa literária não é conhecêla. Como ela é construída no tempo, a leitura traz ao leitor o desbravamento dos meandros do texto, constituindo-o no ato da leitura como um novo sujeito-leitor. A arte, para ser compreendida, precisa ter seu tempo particular de fruição respeitado.

No trecho a seguir, Helena Estevão expõe a semelhança entre a Música e a Literatura, no sentido de ambas serem artes temporais: "Mas os livros acontecem no tempo. Como a música. Os romances, sobretudo. Eram, como a música, uma forma de medir e de organizar o tempo" (GERSÃO, 1997, p. 54). Assim como a Música organiza o tempo, dando a este um sentido através das notas musicais, a Literatura, por meio do tempo narrativo, constrói o "eu" de suas personagens - como Júlia, que está se constituindo como sujeito no encadeamento sucessivo dos acontecimentos e reflexões.

Por isso, o tempo, concebido como mercadoria, é alvo da crítica de Teolinda Gersão em Os Teclados. Talvez a concepção de tempo considerada ideal pela autora, no contexto desta narrativa, receba influências de Platão e Kepler, ambas introduzidas a Júlia por Rogério Souto, o professor de matemática.

\footnotetext{
${ }^{27}$ Na concepção de Walter Benjamin.
} 
Toma-se a teoria de Kepler, tal como aparece na obra de Teolinda Gersão (1999):

\begin{abstract}
Havia relação entre a estrutura do cosmos e a da música. A primeira música era a de cada planeta. O movimento dos planetas era música, a música era o princípio de tudo, a expressão de poderes superiores que governavam o mundo. Cada corpo celeste possuía uma nota e um acorde específico, o conjunto traduzia a harmonia do universo. Aqui em baixo, na Terra, só o ouvido subtil a podia alcançar: através de tudo que existia, podia ouvir-se com esse ouvido interior, a harmonia superior que governava o mundo. (p. 72)
\end{abstract}

A teoria de Kepler não é referida explicitamente na narrativa d'Os Teclados, como a teoria platônica. Todavia, sabe-se que o fragmento acima, integrando a fala do professor Rogério, nada mais é que a segunda lei de Kepler. A autora pode ter desejado orientar a compreensão do leitor acerca dessa concepção de tempo ao citar, logo depois, três estudiosos do tempo, dentre eles Kepler: "Pitágoras, Platão, Kepler, dizia ele." (GERSÃO, 1999, p.76).

Os três filósofos abordam o tempo em uma espécie de encaixe de pensamentos filosóficos, como nos confirma Marcelo Gleiser em seu livro A dança do universo: "Pitágoras é, talvez, o mais lendário filósofo da Antiguidade. [...] Sua filosofia religiosa influenciou e moldou o pensamento de alguns dos maiores filósofos e cientistas da história, incluindo Platão e Kepler" (p.53).

Na sua obra Harmonices Mundi (1619), Kepler imaginou um coro no qual Mercúrio, a voz mais aguda, seria o Soprano, Vênus e Terra, os Contraltos, Marte, o Tenor, enquanto que Júpiter e Saturno, as vozes mais graves, seriam os Baixos. Nesta sua teoria da música celestial, ao planeta Terra correspondia um intervalo musical de meio-tom, que ele associou ao modo eclesiástico de mi (modo frígio), levando-o a concluir que a melodia entoada pela Terra era "mi - fá - mi". Kepler intuiu essa ideia durante a Guerra dos Trinta Anos, o que o levou a pensar que a Terra produzia um lamento constante, em nome da misere e fami (miséria e fome), que reinavam à época. 
Para explicar por que razão não se consegue ouvir a música mundana, Aristóteles argumentava que a ouvimos desde o momento do nascimento, e que, por esta razão, não temos a capacidade de distingui-la do seu oposto, o silêncio.

O narrador da obra Os Teclados refere-se à segunda lei de Kepler. Esta lei, transcrita acima, aborda os sons e a harmonia das esferas celestiais. De modo que cada planeta emitiria um som, e os seres humanos precisariam aperfeiçoar sua capacidade do silêncio, para então, compreender a música celestial. $\mathrm{O}$ aperfeiçoamento de cada um como indivíduo em busca desse silêncio constituiria um processo de autoconhecimento necessário a uma vida harmônica.

Por sua vez, Júlia está traçando uma trajetória de autoconhecimento. Ela se mantém, na maior parte do tempo, em silêncio, desenvolvendo sua capacidade de percepção do mundo e de si. Através desta atenção às coisas, Júlia pode se reordenar pelo tempo, por meio da música, e se constituir como sujeito na medida em que é capaz de se diferenciar, criticamente, dos modelos musicais e éticos que estão ao seu redor. 


\section{Últimos acordes...}

\section{[...] porque a vida era feita de pequenos nadas.}

Teolinda Gersão

O diálogo entre as diversas artes aparece de forma recorrente nas obras de Teolinda Gersão. Em Os Guarda-chuvas Cintilantes, Paisagem com Mulher e Mar ao Fundo e A Árvore das Palavras é nítida a relação com as artes espaciais, como a Fotografia, a Pintura e a Dança, respectivamente. Com relação a Os Teclados, os capítulos anteriores deste trabalho procuraram evidenciar o modo como a inter-relação entre a Literatura e a Música se torna um elemento constitutivo da estrutura da obra.

Nesse sentido, o primeiro capítulo, intitulado "Claves da Narrativa", forneceu ao leitor as diretrizes, isto é, as claves, que indicam o tom de leitura da obra. Convém, aqui, relembrar que esse termo, neste contexto, equivale à ideia central que percorre todo o romance. Assim, a referência e o levantamento de alguns dados biográficos importantes dos três compositores (Mozart, Beethoven e Bach) foram relevantes por apontarem identificações com a construção das personagens e dos espaços de convivência da protagonista. Por exemplo, procurou-se demonstrar que os ideais estéticos e éticos de Mozart e Beethoven ligam-se, de algum modo, aos de Júlia e de tio Octávio, respectivamente. Já a música de Bach (especificamente no que toca à estrutura da fuga), segundo a leitura feita neste estudo, evoca o ambiente familiar de Júlia. Outros indícios importantes para uma leitura interpretativa da obra foram identificados por meio dos mitos (de Er e das Sereias), da metáfora dos teclados, (do piano, do computador, do teclado de papel, da clavinova) e da imagem da trapezista.

No capítulo seguinte, "A regência de Júlia em seus primeiros insights sobre a relação Arte - Público", foram tecidas considerações sobre as mudanças ocorridas no conceito de arte desde o surgimento da fotografia, quando a possibilidade de reprodução do objeto artístico gerou o desaparecimento da sua unicidade e irrepetibilidade. A partir de então, como se pôde ver, a arte se democratizou e se massificou, transformando-se em mera mercadoria. O modo como Júlia toma consciência desse esvaziamento de sentido da Arte é através da leitura da entrevista de Helena Estevão, escritora que, neste trabalho, foi vista como possível alter-ego de Teolinda Gersão e elemento importante no 
desencadeamento do processo de crescimento da protagonista. Tal episódio retrata o eixo da narrativa, pois é então que a garota tem os seus primeiros momentos de consciência tenuemente lúcida.

Chega-se, neste ponto, à etapa mais significativa deste trabalho. A hipótese que se buscou comprovar aqui é a de que a autora d'Os Teclados pretende tecer, ao longo da narrativa, uma série de reflexões sobre a arte e o papel do artista na sociedade contemporânea. A escritora Helena Estevão, em sua entrevista, aborda questões ligadas à indústria cultural, ao artista e seu objeto - no caso, a obra de arte literária - ora considerada com seu valor genuíno de arte, ora considerada como mercadoria. Expõe, também, a preocupação com o possível fim das comunidades interpretativas, uma vez que o mundo contemporâneo tem abolido o debate social como processo de construção de sentidos. As reflexões da escritora na entrevista, associadas ao movimento interno que elas desencadeiam na protagonista, levam o leitor da obra a refletir sobre a Literatura em seu próprio tempo, bem como sobre sua condição de leitor na sua época.

Nesse contexto, pode-se conjeturar que Gersão pressupõe a possibilidade de o leitor d'Os Teclados ter um horizonte de expectativas semelhante ao do leitor aficcionado pela cultura de massas. Se assim for, o seu nível de decodificação será baixo, pois a qualidade da leitura também o será: detalhes importantes poderão passar despercebidos, referências textuais não farão parte do seu horizonte de expectativa etc e, desse modo, a interpretação do texto estará comprometida.

Para desautomatizar esse tipo de leitura e despertar a atenção do leitor, a autora incorpora, estrategicamente, recursos musicais às estruturas literárias, como se fossem elementos que pudessem auxiliar o leitor a "reger" sua leitura. Com esse fim, aparece no texto uma estrutura de polifonia poética, bem como efeitos de andamentos musicais que comandam o fluxo da leitura e, de certo modo, obrigam o leitor a refletir sobre os trechos repetidos nos refrões, ou a pensar sobre as possíveis respostas às indagações que emergem por meio da técnica de retardamento. Assim, ao ter sua leitura orientada pelos recursos musicais incorporados ao tecido do texto, ele sofre os efeitos estéticos d' $O s$ Teclados, passando a executar uma leitura orientada pelos elementos harmônicos do texto.

É como se esse leitor participasse da audição de uma música cujas linhas melódicas fossem metaforizadas por cada personagem do romance, num jogo de vozes que ora se complementam, ora se contrapõem, lembrando uma fuga de Bach (composta, como se viu, pelas vozes contrapontísticas de Tio Octávio, tio Eurico, os professores 
Claudemiro Palrinha, Severiano Mendonça e Madame Ortega, assim como de Ireninha, Lúcia e da própria Júlia).

Nesse sentido, pôde-se verificar, ao longo desta dissertação, que esta obra de Teolinda é construída de modo semelhante a uma partitura, dividida, portanto, em duas partes: melodia e harmonia - a própria Júlia, aliás, faz essa comparação. À melodia corresponderiam as sequências de notas musicais, ou seja, as personagens citadas acima; já a parte harmônica, através de sua estrutura (isto é, os acordes (ou polifonia poética), refrão e a técnica de retardamento), conduz o leitor a refletir sobre os questionamentos expostos no enredo, repetidas vezes, incitando-o, assim, a assumir uma postura de leitor ativo e reflexivo, que traz para o seu processo de leitura toda e qualquer possível contribuição do seu repertório cultural.

Como escritora comprometida com um intenso e constante diálogo com o seu leitor, Teolinda Gersão desejaria dele um tipo de comportamento semelhante ao descrito acima. No entanto, ela tem plena consciência da dificuldade de estabelecer um vínculo dessa ordem, que se mantivesse do começo ao fim da narrativa, sem dispersões que lembrassem, por exemplo, os cochilos de tio Octávio ao ouvir Beethoven.

Nesse contexto, este trabalho procurou acentuar a equivalência reconhecida em Os Teclados entre os atos de ouvir música e ler uma obra literária, na medida em que ambos demandam um exercício (até certo ponto exaustivo) de atenção da parte do ouvinte/leitor. Ao longo da narrativa, esses indícios vão sendo disseminados pela protagonista com a ajuda do narrador, sendo um deles a repetição insistente dos verbos ouvir, ver e outros vocábulos do mesmo campo semântico.

Nesse sentido, quando Júlia enuncia, em pensamento, que ouvir é um segredo a ser descoberto, ela metaforiza o ato de ler, concebido também como um segredo a ser revelado. O enredo d'Os Teclados está repleto de metáforas, ou reverberações, que são apresentadas "discretamente", isto é, são apenas citadas como parte de explicações de professores (como o mito de Er ou as leis de Kepler), ou como reflexões de Júlia (como a que tece sobre a performance da trapezista). Caberá ao leitor desvendar tais metáforas, para, a partir delas, construir o significado do texto e compreender que é o leitor quem, na verdade, está se autodescobrindo enquanto sujeito-leitor.

A Música, por conseguinte, aparece como condutora da atenção do leitor sobre trechos literários importantes para a compreensão da narrativa. Por isso, as técnicas de refrão, retardamento ou polifonia poética são amplamente utilizadas no enredo, conforme tentamos apontar no terceiro e no quarto capítulos, intitulados, "O caminho 
das notas musicais - $1^{\mathrm{a}}$. parte: melodia." e "O caminho dos arpejos músico-textuais d'Os Teclados", respectivamente, desse trabalho. A estratégia utilizada, pela escritora, de repetir palavras ou frases, bem como a de retardar respostas para as diversas perguntas apresentadas no enredo, fazem o leitor refletir sobre as repetições e sobre os questionamentos que elas contêm. Em suma, o enredo, através de sua estrutura músicoliterária, convida o leitor a adotar uma conduta no mínimo próxima à esperada pela autora, isto é, o leitor deve ser instigado pela narrativa a procurar seus "segredos", de modo a expandir, também, a sua própria escuta.

Toda essa engenharia literária acontece a partir do olhar do leitor, que acompanha a trajetória da protagonista em sua autoaprendizagem, constituindo-se como sujeito ético a partir de uma vivência estética. Por conseguinte, o leitor mais atento, perceberá que Júlia, na verdade, é uma projeção metafórica dele mesmo, que também executa uma partitura.

Esse leitor idealizado está sempre em formação, repleto de dúvidas e questionamentos que o fazem buscar a compreensão do texto de algum modo. Obviamente, nenhum leitor dominará plenamente todos os meandros de um texto literário, uma vez que a pluralidade interpretativa faz parte desse tipo de texto, como já afirmou Iser. Desse modo, pode-se intuir que o leitor tido como ideal em Os Teclados está em constante busca pelo conhecimento da obra literária, de modo que, por meio desse contato artístico, ele possa transformar-se a si mesmo. O leitor idealizado por Gersão é como o que observa a trapezista sobre um fio tênue, traçado entre o caos e a organização de um mundo.

A partir da consciência que ele vai ganhando acerca de si mesmo, do ato de ler etc, o leitor passa a pensar sobre seu próprio papel na sociedade contemporânea enquanto leitor ativo ou passivo da obra de arte. Na interpretação desenvolvida neste trabalho, assim, por tal processo, nasce o sujeito-leitor em Os Teclados.

Problematizar a arte demanda que ela seja pensada. Para explorar tal reflexão, o capítulo "A escuta da partitura literária d'Os Teclados" procurou mostrar que, em $O s$ Teclados, não se idealiza um leitor pronto, que, ao ler, tudo compreende, mas sim um leitor em formação, na busca por um autoconhecimento e um aprimoramento no seu ato interpretativo. Nesse sentido, essa análise abordou os efeitos estéticos pelos quais passa o leitor da obra analisada nessa dissertação.

Iser afirma que o ato interpretativo depende não só do texto, mas também da cultura em que está inserido o leitor; por extensão, depende ainda de seu conhecimento 
de mundo. Isso inclui suas referências literárias, musicais, políticas, filosóficas, culturais, seu grau de instrução etc. Dessa maneira, como o ser humano está sempre em transformação, modificando seu repertório cultural, literário e seu amadurecimento como pessoa, o ato interpretativo modifica-se o tempo todo, na mesma medida em que se transforma o leitor, aceitando os desafios, como a trapezista ou o Er sartriano.

Nesse sentido, o fato de a autora ter escolhido uma pré-adolescente como protagonista desta história ressalta a imagem de alguém que está em constante transformação e que apresenta dúvidas em relação aos assuntos mais diversos, como suas relações familiares, seus professores, a formação do universo, o amor ou a música etc. Do mesmo modo que a protagonista, assim também o leitor, ao ler uma obra literária, se depara com questionamentos constantes em relação ao tecido literário, suas metáforas, personagens, referências históricas ou filosóficas etc. Logo, o leitor pode apresentar medo de lançar-se na descoberta do livro, sabendo, conscientemente, que a leitura transforma o ser. Por não sair do ato da leitura do mesmo modo que se encontrava quando a iniciou, o leitor sofre mudanças em sua essência. Desse modo, ele vai, durante o ato da leitura, se autoconstruindo, na medida em que se transforma como autoconsciência.

Ainda a esse mesmo contexto da autodescoberta do leitor aplica-se o mito de Er. A escolha pela conduta de sua vida diz respeito unicamente à sua atitude, não é algo controlado pelo destino. Portanto, pode-se dizer que as escolhas realizadas por cada um em sua trajetória de vida dependem apenas do desejo de cada ser humano e, nesse sentido, ser um bom leitor é uma escolha e não um acaso. Isto é, cada leitor pode formar sua trajetória de leitura buscando aprender mais, ampliando seu repertório cultural para adquirir melhor aptidão no ato interpretativo. O leitor d'Os Teclados pode, no próprio ato da leitura, verificar qual o domínio que possui das referências apresentadas no texto, uma vez que são citados Mozart, Beethoven, Bach, Kepler, Platão, por exemplo. Assim, o leitor, ao ler essas referências, tem condições de analisar o quanto sabe sobre tais metáforas e suas possíveis aplicações ao enredo d'Os Teclados.

Partindo da ideia de que o eixo central da obra é a discussão sobre o leitor e a indústria cultural na contemporaneidade, a partir da observação do percurso realizado pela protagonista em sua autodescoberta, esta pesquisa vislumbrou apresentar, primeiramente, as metáforas que compõem o "segredo" da leitura d'Os Teclados. Parafraseando Júlia, ler é um segredo, assim como "ouvir era um segredo". Posteriormente, a discussão sobre a indústria cultural procurou apontar que n'Os 
Teclados havia uma reflexão sobre o papel da arte na contemporaneidade, bem como sobre o perfil de seu apreciador. E dentro desse contexto, tentou-se apontar para a construção de outro sujeito, agora o leitor, em vez de Júlia. Para que a construção desse leitor fosse melhor apresentada, foi necessária a explicação sobre os elementos musicais dentro da narrativa para que se entendessem, a posteriori, os efeitos estéticos causados no leitor durante a leitura d'Os Teclados.

Por fim, a pesquisa termina pela verificação das possibilidades interpretativas do tempo dentro da obra, principalmente, destacando-o como elemento necessário para a fruição musical e literária. Nesse sentido, o capítulo "O compasso da leitura" questionou, também, sobre um modo de atingir o respeito a esse tempo. Trata-se de um grande problema, pois a sociedade contemporânea deseja o consumo imediato, a fruição instantânea, razão por que se proliferam os resumos de obras literárias e os fragmentos de peças musicais, aparecendo estes como representações legítimas dos originais.

Em síntese, a conclusão a que se chegou neste estudo é de que a obra $O s$ Teclados apresenta um diálogo artístico entre Literatura e Música, sendo que os recursos musicais nela presentes auxiliam a condução do olhar do leitor durante o ato da leitura da obra, apontando para a construção ética do sujeito por meio de uma aprendizagem da fruição estética. Primeiramente, identificou-se a formação de Júlia como sujeito e, posteriormente, foi possível inferir que Júlia, na verdade, é uma projeção de outro sujeito, o leitor, que, ao longo do processo de leitura, vai aprimorando sua consciência interpretativa. Sob esse prisma, ler Os Teclados corresponderia a uma experiência musical do texto literário, no que toca à sua estrutura e sensibilização. 


\section{REFERÊNCIAS BIBLIOGRÁFICAS}

\section{De Teolinda Gersão:}

GERSÃO, Teolinda. O Silêncio. Lisboa: Publicações Dom Quixote, 1981. Paisagem com Mulher e Mar ao Fundo. Lisboa: Publicações Dom Quixote, 1982. O Cavalo de Sol. Lisboa: Publicações Dom Quixote, 1989. A Casa da Cabeça de Cavalo. Lisboa: Publicações Dom Quixote, 1995.

. Os Guarda-chuvas Cintilantes. $2^{\mathrm{a}}$.ed. Lisboa: Publicações Dom Quixote, 1997. A Árvore das Palavras. São Paulo: Planeta, 2004.

Os Teclados. Lisboa: Publicações Dom Quixote, 1999.

\section{Sobre Teolinda Gersão:}

BRIDI, Marlise Vaz. Modernidade e pós-modernidade na ficção portuguesa contemporânea. Revista Todas as Letras, v.07, São Paulo, 2005.

CARETTI, Ana Carolina da Silva. Teclas Paralelas: Dimensão Literário-Musical em Os Teclados, de Teolinda Gersão. 2009. 100f. (Dissertação de mestrado), Universidade Estadual Paulista, Instituto de Biociências, Letras e Ciências Exatas. São José do Rio Preto, 2009. 
DIAS, Maria Heloísa Martins. O Pacto Primordial entre Mulher e Escrita - Teolinda

Gersão e a atual prosa feminina portuguesa. São Paulo: Scortecci, 2008.

A presença de elementos míticos na narrativa de

Teolinda Gersão. Disponível em: http://www.hottopos.com/notand7/heloisa.htm . Acesso em: maio/2008.

LIMA, Isabel Pires. Ainda há contos de fadas? O caso de Os anjos de Teolinda Gersão. Disponível em: HTTP://www.teolinda-gersao.com/art_limaisabelpires.htm. Acesso em: setembro/2007.

LUCAS, Fábio. Música das esferas. Jornal de Letras. Artes \& Ideias. Lisboa, 19 de outubro de 1999.

. Os sons que organizam mundos exteriores e interiores tomando a música como medida de todas as coisas, Os Teclados, de Teolinda Gersão, explora destinos por meio de metáforas da harmonia musical. Disponível em: HTTP: www.teolinda-gersao.com/art_lucasfabio.htm. Acesso em: janeiro/2008.

MENDES, Maria dos Prazeres. A metalinguagem da voz narrativa feminina em Clarice Lispector e Teolinda Gersão. São Paulo, Via Atlântica, nº 01, 1997.

SILVA, Grazielle Katyane dos Santos. Os Guarda-Chuvas Cintilantes, um Insólito diário. 2005. (Dissertação de Mestrado). Universidade Estadual Paulista, Instituto de Biociências, Letras e Ciências Exatas. São José do Rio Preto, 2005.

ZAMBONIM, Maria Tereza Martinho. O Silêncio em Teolinda Gersão.1997, 189f. (Tese de doutorado). Universidade de São Paulo, Faculdade de Filosofia, Letras e Ciências Humanas. São Paulo, 1997.

\section{Geral:}

ADORNO, Theodor W. Notas de Literatura I. São Paulo: Editora 34, 2008. 
Textos Escolhidos:Conceito de Iluminismo (em parceria com Horkeimer) e O fetichismo na Música e a Regressão da Audição. São Paulo: Nova Cultural, 1999.

Indústria Cultural e sociedade. São Paulo: Paz e Terra, 2006.

. Filosofia da Nova Música. São Paulo: Perspectiva, 1989.

AGOSTINHO, Santo. Confissões.Tradução de J. Oliveira Santos e Ambrósio de Pina. São Paulo: Nova Cultural.

ANDRADE, Mário de. "Prefácio Interessantíssimo" in: De Pauliceia Desvairada a café (poesias completas). São Paulo: Círculo do Livro.

Dicionário Musical Brasileiro. Belo Horizonte: Itatiaia, 1999.

ASSIS, Jamile de. Literatura e Música: Diálogos da Crítica. Disponível em: htpp.//www.cult.ufba.br/enecult2007/JamiledeAssis.pdf. Acesso em: setembro/2008.

BENJAMIN, Walter. Magia, técnica, arte e política. São Paulo: Brasiliense, 1985.

BLANCHOT, Maurice. O Espaço Literário. Trad. Álvaro Cabral. Rio de Janeiro: Rocco, 1987.

BUCK-MORSS, Susan. Dialética do olhar. Walter Benjamin e o projeto das passagens. Belo Horizonte: UFMG e Universitária Argos, 2002.

CANDIDO, Antonio. O estudo analítico do poema. São Paulo: Humanitas Publicações FFLCH-USP, 1999.

CHAUÍ, Marilena. Convite à filosofia, São Paulo: Ática, 1997.

COELHO, Nelly Novaes. Literatura e Linguagem - a obra literária e a expressão linguística. Rio de Janeiro: José Olympio, 1974.

COMPAGNON, Antoine. O Demônio da Teoria - Literatura e senso comum. Belo Horizonte: UFMG, 2001.

COPLAND, Aaron. Como ouvir e entender música. Rio de Janeiro: Arte Nova, 1974. 
DAGHLIAN, Carlos. Poesia e Música. São Paulo: Perspectiva, 1985.

DICIONÁRIO CALDAS AULETE. 4ª ed. Rio de Janeiro: Delta, S.A, 1958. (p. 1798, v. 02).

D'ONOFRIO, Salvatore. Literatura Ocidental - autores e obras fundamentais. São Paulo: Ática, 1990.

DROZ, Geneviève. Os mitos platônicos. Brasília: Universidade de Brasília, 1997.

FILHO, J. C. Caldeira. Os compositores. São Paulo: Cultrix, 1999. (Coleção Vidas Ilustres)

FOUCAULT, Michel, $O$ que é um autor? Trad. Antônio Fernando Cascais e Eduardo Cordeiro. Vega: Passagens, 1992.

FREUD, Sigmund, Edição Eletrônica Brasileira das Obras Psicológicas completas de Sigmund Freud, Coordenação de Jaime Salomão. Rio de Janeiro: Imago,1969-80.

GLEISER, Marcelo. A dança do Universo - Dos mitos de criação ao Big - Bang. $2^{\mathrm{a}}$. ed. São Paulo: Cia da Letras, 1998.

GOMES, Álvaro Cardoso. A Voz Itinerante: Ensaio sobre o Romance Português Contemporâneo. São Paulo: Edusp, 1993.

O poético: Magia e iluminação. São Paulo: Perspectiva, 1989.

GRIBBIN, John e Mary. Tempo e espaço - Aventura na ciência. Rio de Janeiro: Globo, 1990.

HAUSER, Arnold. História Social da Literatura e da Arte. Trad. Walter H. Geenen. São Paulo: Mestre Jou, 1980-1982, 2 vols.

HOMERO, Odisseia. Tradução de Antônio Pinto de Carvalho. São Paulo: Abril Cultural, 1981.

ISER, Wolfgang. $O$ ato da leitura - Uma teoria sobre o efeito estético. São Paulo: Editora 34, 1999. (v.2) 
JAUSS, Hans Robert. "Tradição literária e consciência atual da modernidade", in Histórias de Literatura - as novas teorias alemãs. São Paulo: Ática, 1996. (Série Fundamentos)

JEAN \& MASSIN, Brigitte. História da Música Ocidental. Rio de Janeiro: Nova Fronteira, 1997.

JIMENEZ, Marc. O que é Estética? São Leopoldo: UNISINOS, 1999.

LEITE, Ligia Chiappini Moraes. O Foco Narrativo. $3^{\text {a }}$.ed. São Paulo: Ática, 1987 (Série Princípios).

LIMA, Luiz Costa. A literatura e o Leitor - textos de estética da recepção. $2^{a}$.ed. São Paulo: Paz e Terra, 2002.

LUKÁCS, G. Teoria do Romance. São Paulo: Duas Cidades/Editora 34, 2000.

MACHADO, Roberto. Foucault - a filosofia e a literatura. $2^{\text {a }}$.ed. Rio de Janeiro: Jorge Zahar, 2001.

MAGNANI, Sérgio. Expressão e Comunicação na Linguagem da Música. Belo Horizonte: UFMG, 1996.

MATOS, Olgária C. F. O Iluminismo visionário: Benjamin, leitor de Descartes e Kant. São Paulo: Brasiliense, 1993.

MOISÉS, MASSAUD. Panorama da Ficção Portuguesa Moderna. São Paulo: FFLCH/USP, 3:31-42, 1974.

A Criação Literária - Introdução à Problemática da Literatura. 6 .ed. São Paulo: Melhoramentos, 1999.

NIETZSCHE, F. O Nascimento da Tragédia ou Helenismo e Pessimismo. São Paulo: Companhia das Letras, 1992.

NIETZSCHE, Friedrich. A origem da tragédia. 12a .ed. São Paulo: Centauro, 2004. . A genealogia da moral. São Paulo: Escala, 2003. A origem da tragédia, 5a .ed. Lisboa: Guimarães Editores, 1994. 
Genealogia da Moral - uma polêmica. São Paulo: Cia das

Letras, 2002.

.Nietzsche e a verdade. São Paulo: Graal, 1999.

.O nascimento da tragédia ou Helenismo e pessimismo. São

Paulo: Cia das Letras, 1999.

NUNES, Benedito. O tempo na narrativa. São Paulo: Ática, 2003 (Série fundamentos). O dorso do tigre. $2^{a}$.ed. São Paulo: Perspectiva, 1976.

OLINTO, Heidrum Krieger. Histórias de Literatura - as novas teorias alemãs. São Paulo: Ática, 1996. (Série Fundamentos)

OLIVEIRA, Solange Ribeiro de. Literatura e Música. São Paulo: Perspectiva, 2002.

ORLANDI, Eni Puccinelli. As formas do silêncio - no movimento dos sentidos. $6^{\text {a }}$.ed. Campinas: EDUNICAMP, 2007.

PESSOA, Fernando. Obra Poética. Rio de Janeiro: Nova Aguilar, 1986.

PIVA, Luiz. Literatura e Música. Brasília: MusiMed, 1990.

PLATÃO. Diálogos - A República. Tradução Leonel Vallandro. Rio de Janeiro: Ediouro, 1997.

Diálogos II - Fédon - Sofista - Político. Tradução de Jorge Paleikat. Rio de Janeiro - Porto Alegre - São Paulo: Globo, 1998.

PLATZER, Frédéric. Compêndio de Música. Lisboa: Edições 70, 2002.

RUSSEL, Bertrand. História do Pensamento Ocidental. Rio de Janeiro: Ediouro, 2001.

SILVA, Vitor Manuel de Aguiar. Teoria da Literatura. $8^{\text {a }}$.ed. Coimbra: Livraria Almedina, 1993. (v.01)

SOUZA, T.M. O mito de Er: Sartre e o platonismo às avessas? In: Cadernos de Ética e Filosofia Política, nº 08, 2006, p.107-118.

STAM, Robert. Bakhtin - da teoria literária à cultura de massa. São Paulo: Ática, 1992. 
TEIXEIRA, Descartes de S., Mozart - vida, obra e suas relações com a maçonaria. São Paulo: Traço, 1991.

WISNIK, J.M. O som e o sentido. São Paulo: Companhia das Letras, 1989.

ZILBERMAN, Regina. Estética da recepção e história da literatura. São Paulo: Ática, 2004. (Série Fundamentos) 